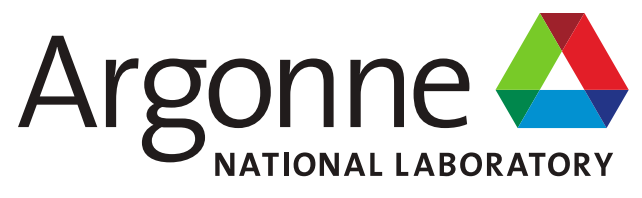

\title{
Verification and Validation of PARET/ANL Version 7.6
}

Nuclear Science \& Engineering Division 


\title{
About Argonne National Laboratory
}

Argonne is a U.S. Department of Energy laboratory managed by UChicago Argonne, LLC under contract DE-AC02-06CH11357. The Laboratory's main facility is outside Chicago, at 9700 South Cass Avenue, Argonne, Illinois 60439. For information about Argonne and its pioneering science and technology programs, see www.anl.gov.

\section{DOCUMENT AVAILABILITY}

Online Access: U.S. Department of Energy (DOE) reports produced after 1991 and a growing number of pre-1991 documents are available free at OSTI.GOV (http://www.osti.gov/), a service of the U.S. Dept. of Engery's Office of Scientific and Technical Information.

\author{
Reports not in digital format may be purchased by the public from the \\ National Technical Information Service (NTIS): \\ U.S. Department of Commerce \\ National Technical Information Service \\ 5301 Shawnee Rd \\ Alexandria, VA 22312 \\ www.ntis.gov \\ Phone: (800) 553-NTIS (6847) or (703) \\ 605-6000 Fax: (703) 605-6900 \\ Email: orders@ntis.gov
}

\section{Reports not in digital format are available to DOE and DOE contractors from the Office of Scientific and Technical Information (OSTI):}

U.S. Department of Energy

Office of Scientific and Technical Information

P.O. Box 62

Oak Ridge, TN 37831-0062

www.osti.gov

Phone: (865) 576-8401

Fax: (865) 576-5728

Email: reports@osti.gov

Disclaimer

\section{Disclaimer}

This report was prepared as an account of work sponsored by an agency of the United States Government. Neither the United States Government nor any agency thereof, nor UChicago Argonne, LLC, nor any of their employees or officers, makes any warranty, express or implied, or assumes any legal liability or responsibility for the accuracy, completeness, or usefulness of any information, apparatus, product, or process disclosed, or represents that its use would not infringe privately owned rights. Reference herein to any specific commercial product, process, or service by trade name, trademark, manufacturer, or otherwise, does not necessarily constitute or imply its endorsement, recommendation, or favoring by the United States Government or any agency thereof. The views and opinions of document authors expressed herein do not necessarily state or reflect those of the United States Government or any agency thereof, Argonne National Laboratory, or UChicago Argonne, LLC. 


\section{Verification and Validation of PARET/ANL Version 7.6}

prepared by

A. P. Olson, M. Kalimullah, and S. H. Pham

Nuclear Science \& Engineering Division, Argonne National Laboratory

December 2020 


\section{ERRATA}

\begin{tabular}{|c|c|c|}
\hline Location & Error & Correction \\
\hline Table 2.22 & Column title & $\begin{array}{l}\text { Removed "Single-Phase" from the title of the third } \\
\text { column }\end{array}$ \\
\hline Table A.1 & Values & $\begin{array}{l}\text { Updated "Acceptance Value" and "Tolerance" } \\
\text { columns for all rows }\end{array}$ \\
\hline Table A. 2 & Values & $\begin{array}{l}\text { Updated "Acceptance Value" and "Tolerance" } \\
\text { columns for all rows }\end{array}$ \\
\hline Table A.4 & Values & $\begin{array}{l}\text { Updated "Acceptance Value" and Tolerance" } \\
\text { columns for all rows }\end{array}$ \\
\hline Table A.5 & Column title & Changed a column title from "A04_04" to "A04_05" \\
\hline Table A.6 & Values & $\begin{array}{l}\text { Updated the acceptance values of H.T. Coefficient } \\
\text { for test case A05_01 to " } 2475.06 \text { " and for test case } \\
\text { A05_08 to "9294.79" }\end{array}$ \\
\hline Table A. 9 & $\begin{array}{l}\text { Identification of test } \\
\text { cases }\end{array}$ & $\begin{array}{l}\text { Changed test cases from "B02_01" to "B01_05", and } \\
\text { from "B02_21" to "B01_21" }\end{array}$ \\
\hline Table A.14 & Values & $\begin{array}{l}\text { Updated "Reference Time" and "Acceptance Value" } \\
\text { for all rows }\end{array}$ \\
\hline
\end{tabular}




\section{Abstract}

This report documents the software testing which has been performed for the PARET/ANL version 7.6 software. The capabilities addressed in this testing were selected based on the use of the software for analysis work under the Research and Test Reactors Department quality assurance program. The verification and validation have been performed and documented to address the steady-state capabilities of the software, as described in Chapter 2, and the transient capabilities, as described in Chapter 3. Testing based on the comparison between PARET/ANL calculations and analytical solutions, hand calculations, or another code calculations of the test cases confirms that all the identified capabilities of the software were implemented correctly. 


\section{Table of Contents}

Abstract .. $\mathbf{i}$

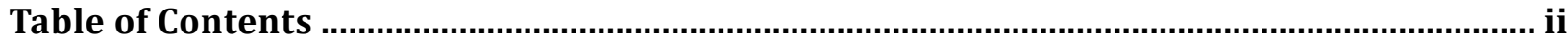

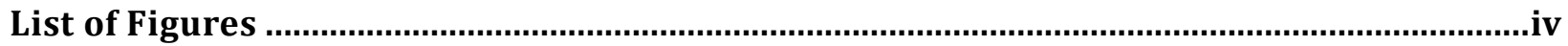

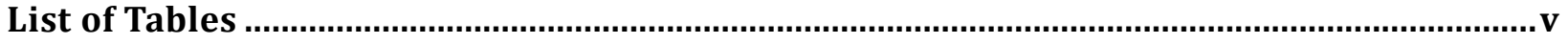

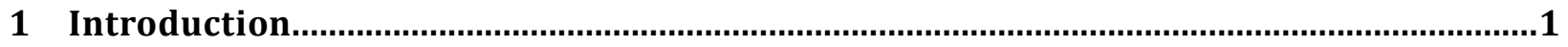

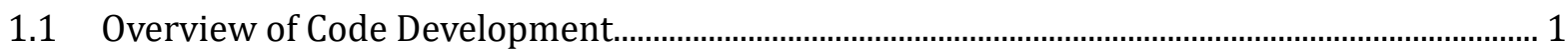

1.2 Code Capabilities and Verification Approaches.............................................................................. 2

2 Verification of Steady-State Capabilities.........................................................................

2.1 Capability A1 - Coolant Properties …………................................................................................ 5

2.1.1 Light Water Properties ............................................................................................................. 5

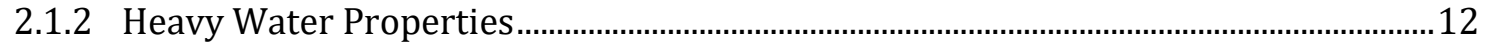

2.2 Capability A2 - Solid Material Thermal Properties ..............................................................................18

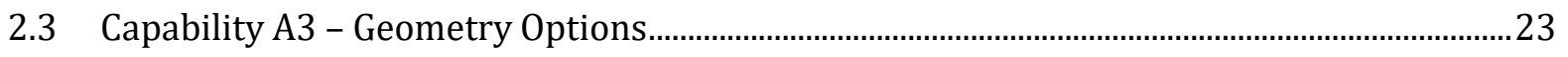

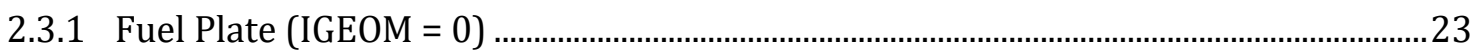

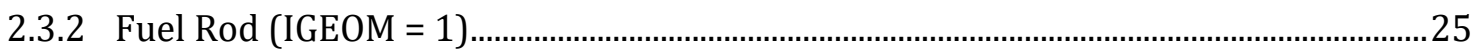

2.3.3 Fuel Plate with Different Channel Geometries (IGEOM = 2) ...........................................26

2.4 Capability A4 - Flow Options (Forced or Buoyancy-Driven Flow)............................................27

2.5 Capability A5 - Single-Phase Heat Transfer Correlations ……........................................................30

2.5.1 Description of Code Calculation Method ....................................................................30

2.5.2 Verification Approach ..................................................................................................... 31

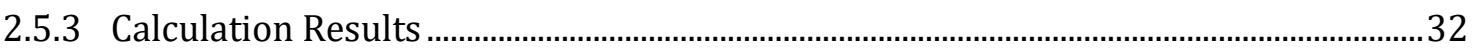

2.6 Capability A6 - Factor Used for Fin or Bundle Effect........................................................................

2.7 Capability A7 - Subcooled Nucleate Boiling Heat Transfer ...........................................................34

2.8 Capability A8 - Friction Factor Correlations ……….........................................................................

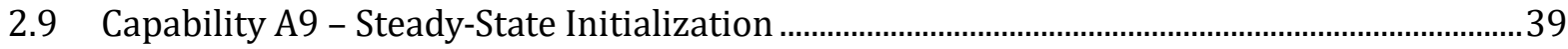

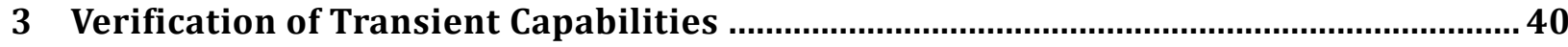

3.1 Capability B1 - Point Kinetics Model...................................................................................................... 40

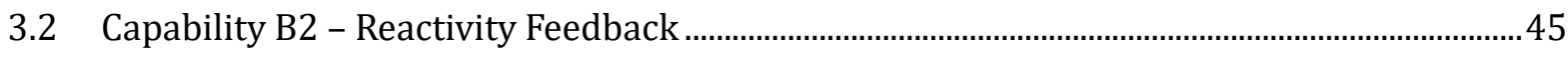

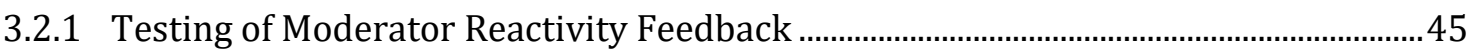

3.2.2 Testing of Doppler Feedback ……...................................................................................... 48

3.2.3 Testing of Feedback due to Thermal Expansion ..................................................................49

3.3 Capability B3 - Reactor Trips and Delay Time ...................................................................................51

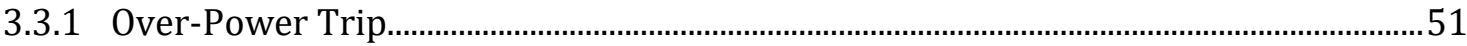

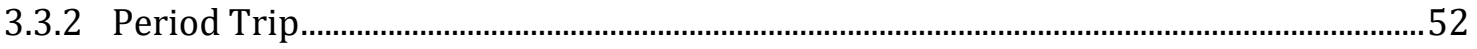




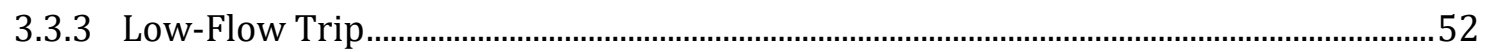

3.4 Capability B4 - Control Rod Reactivity ……….............................................................................53

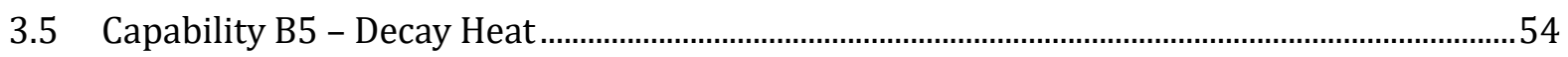

3.6 Capability B6 - Power-Driven Mode ..................................................................................................5

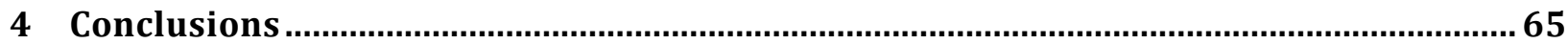

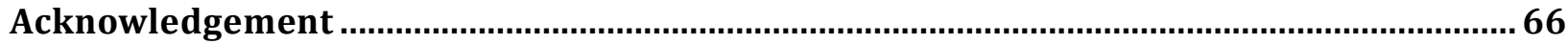

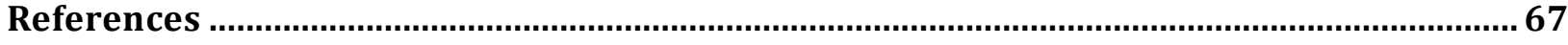

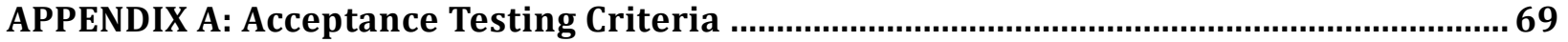




\section{List of Figures}

Figure 2.1. Comparison of $\mathrm{H}_{2} \mathrm{O}$ Enthalpy between PARET/ANL and NIST Data......................................... 7

Figure 2.2. Comparison of $\mathrm{H}_{2} \mathrm{O}$ Thermal Conductivity between PARET/ANL and NIST Data................. 8

Figure 2.3. Comparison of $\mathrm{H}_{2} \mathrm{O}$ Specific Heat Capacity between PARET/ANL and NIST Data ................ 9

Figure 2.4. Comparison of $\mathrm{H}_{2} \mathrm{O}$ Density between PARET/ANL and NIST Data..........................................10

Figure 2.5. Comparison of $\mathrm{H}_{2} \mathrm{O}$ Viscosity between PARET/ANL and NIST Data........................................11

Figure 2.6. Comparison of $\mathrm{D}_{2} \mathrm{O}$ Enthalpy between PARET/ANL and NIST Data........................................13

Figure 2.7. Comparison of $\mathrm{D}_{2} \mathrm{O}$ Thermal Conductivity between PARET/ANL and NIST Data................14

Figure 2.8. Comparison of $\mathrm{D}_{2} \mathrm{O}$ Specific Heat Capacity between PARET/ANL and NIST Data ...............15

Figure 2.9. Comparison of $\mathrm{D}_{2} \mathrm{O}$ Density between PARET/ANL and NIST Data..........................................16

Figure 2.10. Comparison of $\mathrm{D}_{2} \mathrm{O}$ Viscosity between PARET/ANL and NIST Data ......................................17

Figure 2.11. Input Data of (a) Power History and (b) Axial Power Distribution........................................18

Figure 2.12. Axial Meshing Systems of (a) PARET/ANL and (b) RELAP5 Codes ......................................20

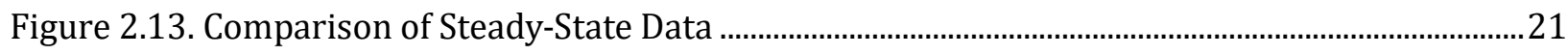

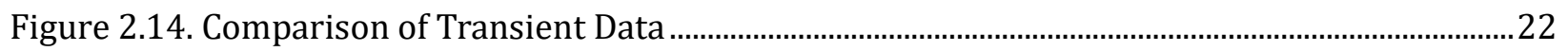

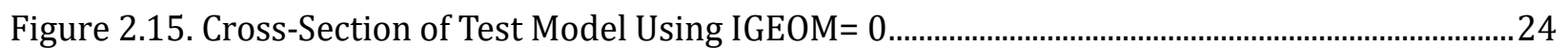

Figure 2.16. Cross-Section of Test Model Using IGEOM = 1 …................................................................25

Figure 2.17. Cross-Section of Test Model Using IGEOM = 2 ….............................................................26

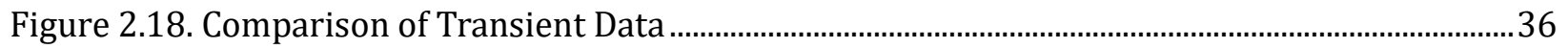

Figure 2.19. Comparison of Friction Factor between PARET/ANL and Mathematica .............................38

Figure 3.1. Imposed Reactivity for The Verification Problem with Feedback. .........................................43

Figure 3.2. Feedback Reactivity for the Verification Problem with Feedback. ..........................................44

Figure 3.3. Reactor Power for the Verification Problem with Feedback.......................................................44

Figure 3.4. Total Reactivity Calculated by PARET/ANL …..................................................................................54

Figure 3.5. Comparison of Power Table of 51 Time Points with Reactivity Driven Case........................59

Figure 3.6. Comparison of Power Table of 100 Time Points with Reactivity Driven Case.....................59

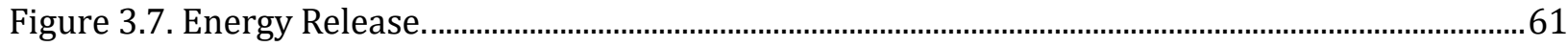

Figure 3.8. Peak Fuel Temperature in Channel 1 ……......................................................................................61

Figure 3.9. Peak Coolant Temperature in Channel 1 ....................................................................................62

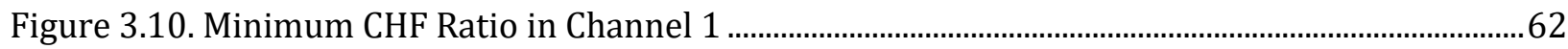

Figure 3.11. Coolant Temperatures in Channel 2.....................................................................................63

Figure 3.12. Cladding Surface Temperatures in Channel 2....................................................................63

Figure 3.13. Maximum Fuel Temperatures in Channel 2 ..............................................................................64 


\section{List of Tables}

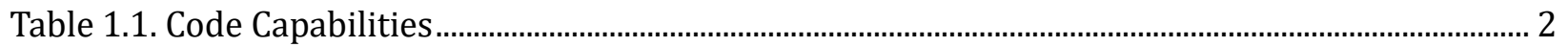

Table 2.1. Comparison of Saturation Temperature Data between PARET/ANL and NIST ...................... 5

Table 2.2. Maximum Difference in $\mathrm{H}_{2} \mathrm{O}$ Properties between PARET/ANL and NIST Data........................ 6

Table 2.3. Maximum difference in $\mathrm{D}_{2} \mathrm{O}$ properties between PARET/ANL and NIST Data ......................12

Table 2.4. Specifications of Test Case A02_01 …….......................................................................................19

Table 2.5. Comparison of Transient Park Temperatures ...................................................................................23

Table 2.6. Input Parameters of Test Problem with IGEOM = 0 ................................................................24

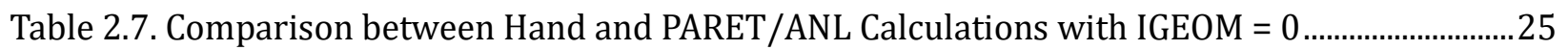

Table 2.8. Input Parameters of Test Problem with IGEOM = 1 .....................................................................26

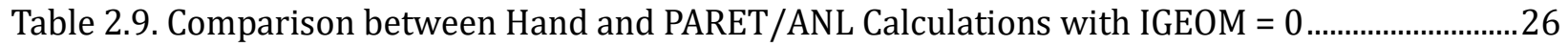

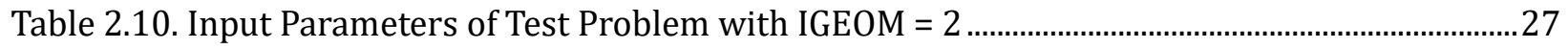

Table 2.11. Comparison between Hand and PARET/ANL Calculations with IGEOM = 2 .......................27

Table 2.12. Flow Options and Test Case ............................................................................................................28

Table 2.13. Input Parameters of Test Problem IFLOW = 5 (test case A04_04)..........................................28

Table 2.14. Results of Test Problem with IFLOW = 5 (test case A04_04) ….................................................28

Table 2.15. Input Parameters of Test Problem of IFLOW = 1, 3, 4, and 5 (cases A04_01, A04_02, A04_03,

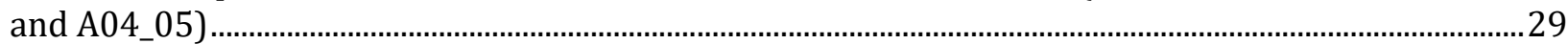

Table 2.16. Comparison of Calculation Results ....................................................................................................29

Table 2.17. Single-Phase Heat Transfer Correlation [2]...................................................................................30

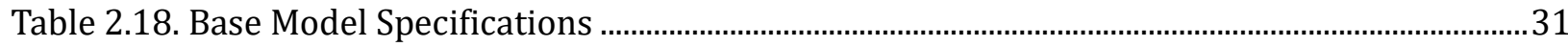

Table 2.19. Input Setting for Test Cases.................................................................................................................

Table 2.20. Comparison of PARET/ANL and Hand Calculations ...................................................................33

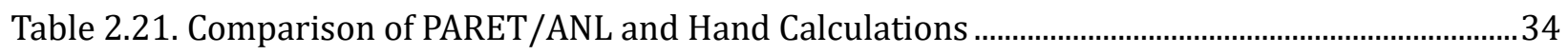

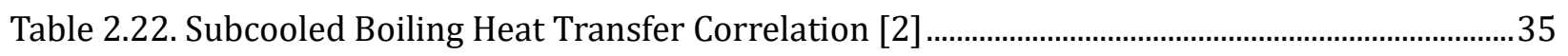

Table 2.23. Comparison of Transient Peak Temperatures ............................................................................ 37

Table 2.24. Friction Factor Correlation for Unheated Channel [2] ...............................................................37

Table 2.25. Comparison of PARET/ANL and Hand Calculations .....................................................................38

Table 2.26. Comparison of PARET/ANL and Hand Calculations ………............................................................39

Table 3.1. Test Cases Used for the Verification of the Point Kinetics Model .............................................40

Table 3.2. Comparison of Solutions Obtained for Step Reactivity Insertions ............................................4

Table 3.3. Comparison of Solutions Obtained for Ramp Reactivity Insertions .........................................42

Table 3.4. Calculation Results ............................................................................................................................... 47

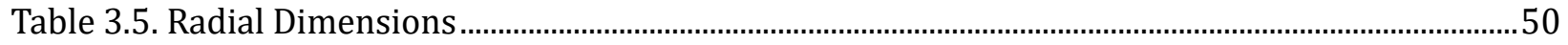

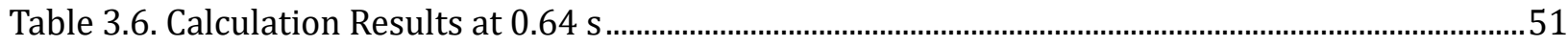


Table 3.7. Test Cases Used for Verification of Decay Heat Calculation........................................................55

Table 3.8. Comparison of Calculations Using 2005 ANS Standard ...............................................................56

Table 3.9. Comparison of Calculations Using 1973 ANS Standard ..............................................................56

Table 3.10. Comparison for a Trip Power of 38.4 MW and Delay Time of $10 \mathrm{~ms}$......................................57

Table 3.11. Comparison for a Prior Irradiation of 3 Days with $Q=210 \mathrm{MeV} /$ fission..............................57

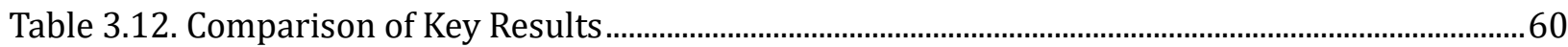

Table A.1. Test Cases A01_01 to A01_11 - Light Water Properties .................................................................69

Table A.2. Test Cases A01_12 to A01_22 - Heavy Water Properties .............................................................71

Table A.3. Test Cases A02_01 and A07_01 - Solid Properties and Nucleate Boiling Model....................74

Table A.4. Test Cases A03_01, A03_02, and A03_03 - Geometry Options .....................................................75

Table A.5. Test Cases A04_01, A04_02, A04_03, and A04_05 - Flow Options ..............................................75

Table A.6. Test Cases A05_01 to A5_10 - Single-phase Heat Transfer ........................................................75

Table A.7. Test Cases A06_01 and A6_02 - Fin or Bundle Effect ................................................................76

Table A.8. Test Cases A08_01 to A08_04 - Friction Factor..........................................................................76

Table A.9. Test Cases B01_05, B01_21, and B01_29 - Point Kinetic Model....................................................76

Table A.10. Test Cases B02_01, B02_06, and B02_09 - Reactivity Feedback.............................................77

Table A.11. Test Cases B03_01 to B03_04 - Reactor Trip and Delay Time..................................................77

Table A.12. Test Cases B04_01 - Control Rod Reactivity ................................................................................78

Table A.13. Test Cases B05_05 and B05_06 - Decay Heat.................................................................................79

Table A.14. Test Cases B06_03 - Power-Driven Mode...........................................................................................79 


\section{Introduction}

\subsection{Overview of Code Development}

The PARET/ANL computer code was originally created in 1969 [1] at Argonne-West in Idaho, which is now part of Idaho National Laboratory (INL), to analyze accidents caused by reactivity insertion events in reactor cores cooled by light or heavy water and with fuel composed of either plates or pins. PARET/ANL can also be used to analyze reactors with fuel assemblies having curved fuel plates when the radius of curvature for each plate is large compared to the plate thickness. Development of the PARET/ANL code [2], [3] has continued at Argonne National Laboratory (ANL) under the sponsorship of the U.S. Department of Energy (DOE) and National Nuclear Security Administration (NNSA). The code has been used by the NNSA Reactor Conversion Program (formerly the Global Threat Reduction Initiative, GTRI, and Reduced Enrichment for Research and Test Reactor, RERTR, Programs) to analyze the expected transient behavior of a large number of reactors.

PARET/ANL models the various fueled regions of a reactor core as channels. Each of these channels (referred from here on as a PARET/ANL channel) consists of a single flat fuel plate or pin (including cladding and, optionally, a gap) surrounded with water coolant. In the case of plate-type fuel elements, the coolant channels on each side of the plate have identical dimensions (with mirror symmetry). There can be many channels, which are not required to have identical dimensions, but each channel is independent thermal-hydraulically, and coupled to the whole core only through reactivity feedback effects. PARET/ANL was originally developed to model reactors cooled by an open loop, which was adequate for rapid transients in pool-type cores.

The time-dependent differential equations that represent the system are replaced by an equivalent set of finite-difference equations in space and time. These are integrated numerically. PARET/ANL uses the solution method developed by Cohen [4] to solve the point-kinetics equations. This same numerical scheme is used to integrate the point-kinetics equations in RELAP5-3D [5]. Heat removal from each PARET/ANL channel occurs in solid materials by conduction perpendicular to the direction of coolant flow and by convection within the coolant channels using a one-dimensional, thermalhydraulic model. Material properties such as heat capacity and thermal conductivity in the solid materials are temperature dependent. Coolant properties such as enthalpy, density, thermal conductivity and viscosity are temperature and pressure dependent. These parameters are used in determining friction factors and heat transfer coefficients. For any given problem, the code first determines the steady-state solution for the initial state. Then the solution of the transient is obtained by integration in time and space.

PARET/ANL contains logic models for trips on period, power, and flow. It contains a model for decay heat after shutdown, and a model for control rod reactivity versus time or position. Feedback reactivity effects from coolant density changes and temperature changes are represented by coefficients and/or tables. Feedback reactivity from fuel heat-up (Doppler Effect) is represented by a four-term polynomial in powers of fuel temperature. Delayed neutron group data are provided by tabular input. Photo-neutrons produced in beryllium or in heavy water may be included in the pointkinetics equations by using additional delayed neutron groups. 


\subsection{Code Capabilities and Verification Approaches}

As shown in Table 1.1, the code capabilities used in analysis work are organized into two general categories, steady-state and transient. Each capability is verified through the comparison between PARET/ANL calculations and analytical solutions, hand calculations, or another code calculations of the test cases. Note that the V\&V of nine steady-state and six transient code capablities are documented to reflect the most commonly used features, while other code evaluations including the V\&V performed with previous code versions are currently not included in this document.

Table 1.1 also lists the test cases included in the acceptance test which can be used to confirm that a newly complied or installed version of the code provides similar results as those obtained with the version considered in the current $V \& V$. Note that although multiple test cases are created to support the $\mathrm{V} \& \mathrm{~V}$ discussion of a particular code capability, some of them are run using the same calculation scheme implemented in the code and therefore, the acceptance test needs to consider representative cases only.

Table 1.1. Code Capabilities

\begin{tabular}{|c|c|c|c|c|}
\hline Capability & \multicolumn{2}{|c|}{ Description } & $\begin{array}{c}\text { Test Case } \\
(\mathrm{R}=\text { reused) }\end{array}$ & $\begin{array}{c}\text { Acceptance } \\
\text { Test }\end{array}$ \\
\hline \multicolumn{5}{|l|}{ Steady-state } \\
\hline \multirow{22}{*}{ A1 } & \multirow{22}{*}{ Coolant properties } & \multirow{11}{*}{ Light water } & A01_01 & $\checkmark$ \\
\hline & & & A01_02 & $\checkmark$ \\
\hline & & & A01_03 & $\checkmark$ \\
\hline & & & A01_04 & $\checkmark$ \\
\hline & & & A01_05 & $\checkmark$ \\
\hline & & & A01_06 & $\checkmark$ \\
\hline & & & A01_07 & $\checkmark$ \\
\hline & & & A01_08 & $\checkmark$ \\
\hline & & & A01_09 & $\checkmark$ \\
\hline & & & A01_10 & $\checkmark$ \\
\hline & & & A01_11 & $\checkmark$ \\
\hline & & \multirow{11}{*}{ Heavy water } & A01_12 & $\checkmark$ \\
\hline & & & A01_13 & $\checkmark$ \\
\hline & & & A01_14 & $\checkmark$ \\
\hline & & & A01_15 & $\checkmark$ \\
\hline & & & A01_16 & $\checkmark$ \\
\hline & & & A01_17 & $\checkmark$ \\
\hline & & & A01_18 & $\checkmark$ \\
\hline & & & A01_19 & $\checkmark$ \\
\hline & & & A01_20 & $\checkmark$ \\
\hline & & & A01_21 & $\checkmark$ \\
\hline & & & A01_22 & $\checkmark$ \\
\hline A2 & \multicolumn{2}{|c|}{ Solid material thermal properties } & A02_01 & $\checkmark$ \\
\hline \multirow{3}{*}{ A3 } & \multirow{3}{*}{ Geometry options } & Fuel plate $($ IGEOM $=0)$ & A03_01 & $\checkmark$ \\
\hline & & Fuel rod (IGEOM = 1) & A03_02 & $\checkmark$ \\
\hline & & Fuel plate $($ IGEOM = 2) & A03_03 & $\checkmark$ \\
\hline \multirow{3}{*}{ A4 } & \multirow{3}{*}{$\begin{array}{l}\text { Forced flow or } \\
\text { buoyancy-driven flow }\end{array}$} & IFLOW $=1$ & A04_01 & $\checkmark$ \\
\hline & & $\mathrm{IFLOW}=3$ & A04_02 & $\checkmark$ \\
\hline & & IFLOW $=4$ & A04_03 & $\checkmark$ \\
\hline
\end{tabular}


ANL/RTR/TM-16/6 Rev. 1

\begin{tabular}{|c|c|c|c|c|}
\hline & & II & A04_04 & \\
\hline & & IFLOW = 5 & A04_05 & $\checkmark$ \\
\hline \multirow{10}{*}{ A5 } & \multirow{10}{*}{$\begin{array}{l}\text { Single-phase heat } \\
\text { transfer correlations }\end{array}$} & \multirow{3}{*}{ Laminar } & A05_01 & $\checkmark$ \\
\hline & & & A05_02 & $\checkmark$ \\
\hline & & & A05_03 & $\checkmark$ \\
\hline & & Transition & A05_04 & $\checkmark$ \\
\hline & & \multirow{6}{*}{ Turbulent } & A05_05 & $\checkmark$ \\
\hline & & & A05_06 & $\checkmark$ \\
\hline & & & A05_07 & $\checkmark$ \\
\hline & & & A05_08 & $\checkmark$ \\
\hline & & & A05_09 & $\sqrt{ }$ \\
\hline & & & A05_10 & $\sqrt{ }$ \\
\hline \multirow{4}{*}{ A6 } & \multirow{4}{*}{\multicolumn{2}{|c|}{ Factor used for fin or bundle effect }} & A05_05(R) & \\
\hline & & & A05_06(R) & \\
\hline & & & A06_01 & $\checkmark$ \\
\hline & & & A06_02 & $\sqrt{ }$ \\
\hline \multirow{2}{*}{ A7 } & \multirow{2}{*}{\multicolumn{2}{|c|}{ Subcooled nucleate boiling heat transfer }} & A02_01(R) & \\
\hline & & & A07_01 & $\checkmark$ \\
\hline \multirow{4}{*}{ A8 } & \multirow{4}{*}{ Friction factor model } & & A08_01 & $\checkmark$ \\
\hline & & $\operatorname{Re} \leq 2000$ & A08_02 & $\checkmark$ \\
\hline & & $2000<\operatorname{Re} \leq 100,000$ & A08_03 & $\checkmark$ \\
\hline & & $\operatorname{Re}>100,000$ & A08_04 & $\checkmark$ \\
\hline \multirow{2}{*}{ A9 } & \multirow{2}{*}{\multicolumn{2}{|c|}{ Steady-state initialization }} & A05_01(R) & \\
\hline & & & A09_01 & \\
\hline \multicolumn{5}{|l|}{ Transient } \\
\hline \multirow{25}{*}{ B1 } & \multirow{25}{*}{ Point kinetic model } & \multirow{20}{*}{$\begin{array}{l}\text { With step reactivity } \\
\text { insertion }\end{array}$} & B01_01 & \\
\hline & & & B01_02 & \\
\hline & & & B01_03 & \\
\hline & & & B01_04 & \\
\hline & & & B01_05 & $\checkmark$ \\
\hline & & & B01_06 & \\
\hline & & & B01_07 & \\
\hline & & & B01_08 & \\
\hline & & & B01_09 & \\
\hline & & & B01_10 & \\
\hline & & & B01_11 & \\
\hline & & & B01_12 & \\
\hline & & & B01_13 & \\
\hline & & & B01_14 & \\
\hline & & & B01_15 & \\
\hline & & & B01_16 & \\
\hline & & & B01_17 & \\
\hline & & & B01_18 & \\
\hline & & & B01_19 & \\
\hline & & & B01_20 & \\
\hline & & \multirow{5}{*}{$\begin{array}{l}\text { With ramp reactivity } \\
\text { insertion }\end{array}$} & B01_21 & $\checkmark$ \\
\hline & & & B01_22 & \\
\hline & & & B01_23 & \\
\hline & & & B01_24 & \\
\hline & & & B01_25 & \\
\hline
\end{tabular}


ANL/RTR/TM-16/6 Rev. 1

\begin{tabular}{|c|c|c|c|c|}
\hline & & & B01_26 & \\
\hline & & & B01_27 & \\
\hline & & & B01_28 & \\
\hline & & With feedback & B01_29 & $\checkmark$ \\
\hline \multirow{11}{*}{ B2 } & \multirow{11}{*}{ Reactivity feedback } & \multirow{5}{*}{ Moderator } & B02_01 & $\checkmark$ \\
\hline & & & B02_02 & \\
\hline & & & B02_03 & \\
\hline & & & B02_04 & \\
\hline & & & B02_05 & \\
\hline & & \multirow{3}{*}{ Doppler Effect } & B02_06 & $\checkmark$ \\
\hline & & & B02_07 & \\
\hline & & & B02_08 & \\
\hline & & \multirow{3}{*}{ Thermal expansion } & B02_09 & $\checkmark$ \\
\hline & & & B02_10 & \\
\hline & & & B02_11 & \\
\hline \multirow{4}{*}{ B3 } & \multirow{4}{*}{$\begin{array}{l}\text { Reactor trips and } \\
\text { Delay time }\end{array}$} & Over-power trip & B03_01 & $\checkmark$ \\
\hline & & Period trip & B03_02 & $\checkmark$ \\
\hline & & \multirow{2}{*}{ Low flow trip } & B03_03 & $\checkmark$ \\
\hline & & & B03_04 & $\checkmark$ \\
\hline B4 & \multicolumn{2}{|l|}{ Control rod reactivity } & B04_01 & $\checkmark$ \\
\hline \multirow{8}{*}{ B5 } & \multirow{8}{*}{\multicolumn{2}{|c|}{ Decay heat }} & B05_01 & \\
\hline & & & B05_02 & \\
\hline & & & B05_03 & \\
\hline & & & B05_04 & \\
\hline & & & B05_05 & $\checkmark$ \\
\hline & & & B05_06 & $\checkmark$ \\
\hline & & & B05_07 & \\
\hline & & & B05_08 & \\
\hline \multirow{3}{*}{ B6 } & \multirow{3}{*}{\multicolumn{2}{|c|}{ Power-driven mode }} & B06_01 & \\
\hline & & & B06_02 & \\
\hline & & & B06_03 & $\checkmark$ \\
\hline
\end{tabular}

As presented below, Sections 2 and 3 describe the verification of steady-state and transient capabilities, respectively. After the conclusion presented in Section 4, acceptance criteria including values and uncertainties of output parameters that need to be monitored for each test case are given in Appendix A. 


\section{Verification of Steady-State Capabilities}

\subsection{Capability A1 - Coolant Properties}

PARET/ANL uses fitting equations to generate temperature-dependent and pressure-dependent properties of both light water and heavy water. The properties needed to be checked are saturation temperature $\left(T_{\text {sat }}\right)$, enthalpy $(H)$, thermal conductivity $(k)$, specific heat capacity $(C p)$, density $(\rho)$, and viscosity $(\mu)$. This capability is verified by comparing the code calculated data of a series of test cases with corresponding results published on the National Institute of Standards and Technology (NIST) website [6]. As discussed below, it can be concluded that the coolant properties generated by the code are adequate for the current safety analyses of the research reactors.

Because the code generates tables of coolant properties before performing the main calculation, the input settings for geometry, material, and reactor kinetic aspects do not impact the consideration of this capability. Therefore, very simple test cases with short transient time $(0.1 \mathrm{~s})$ are used for the comparison. Two series of test cases were run for light and heavy water coolants at 11 different inlet pressures ranging from 1 bar to 125 bar, by changing (i) the input value of inlet pressure, PRESUR, i.e., PRESUR = 1, 2, ..., 125 bar, and (ii) the input value of coolant reference density, RHOREF, i.e., the coolant density at inlet pressure and temperature.

The comparison of obtained data is firstly performed for the saturation temperatures. As shown in Table 2.1, the calculated saturation temperatures over the pressure range from 1 to 125 bar agree very well with NIST values for both light and heavy water.

Table 2.1. Comparison of Saturation Temperature Data between PARET/ANL and NIST

\begin{tabular}{|c|c|c|c|c|c|c|c|c|}
\hline \multirow{2}{*}{$\begin{array}{c}\text { Pressure, } \\
\text { Bar }\end{array}$} & \multicolumn{9}{|c|}{ Light Water } & \multicolumn{5}{c|}{ Heavy Water } \\
\cline { 2 - 9 } & Test Case & PARET/ANL & NIST & Diff., \% & Test Case & PARET/ANL & NIST & Diff., \% \\
\hline & A01_01 & 99.632 & 99.606 & 0.026 & A01_12 & 101.07 & 101.05 & 0.015 \\
\hline 1 & A01_02 & 120.23 & 120.21 & 0.017 & A01_13 & 121.41 & 121.41 & 0.002 \\
\hline 2 & A01_03 & 151.85 & 151.83 & 0.012 & A01_14 & 152.64 & 152.65 & 0.005 \\
\hline 5 & A01_04 & 179.88 & 179.88 & 0.002 & A01_15 & 180.37 & 180.38 & 0.007 \\
\hline 10 & A01_05 & 212.37 & 212.38 & 0.004 & A01_16 & 212.52 & 212.51 & 0.003 \\
\hline 20 & A01_06 & 233.84 & 233.85 & 0.006 & A01_17 & 233.77 & 233.75 & 0.008 \\
\hline 30 & A01_07 & 250.33 & 250.35 & 0.008 & A01_18 & 250.10 & 250.07 & 0.011 \\
\hline 40 & A01_08 & 263.91 & 263.94 & 0.010 & A01_19 & 263.54 & 263.51 & 0.012 \\
\hline 50 & A01_09 & 290.51 & 290.54 & 0.008 & A01_20 & 289.85 & 289.81 & 0.012 \\
\hline 75 & A01_10 & 310.96 & 311.00 & 0.012 & A01_21 & 310.07 & 310.04 & 0.011 \\
\hline 100 & A01_11 & 327.78 & 327.81 & 0.010 & A01_22 & 326.69 & 326.67 & 0.006 \\
\hline 125 & \multicolumn{9}{|c|}{} & & & &
\end{tabular}

The checking of remaining fluid properties are performed for both liquid and vapor states and presented in the following subsections.

\subsubsection{Light Water Properties}

The maximum differences in light water properties between PARET/ANL and NIST for all tested temperatures are presented in Table 2.2, while the detailed results for each property are showed in Figure 2.1 to Figure 2.5. Generally, PARET/ANL results agree quite well with the NIST data but there are differences between the two, especially at pressures $>5$ bar. Note that the code tracks enthalpy, 
and deduces temperature from enthalpy. Changes in enthalpy are not computed based on heat capacity $(C p)$. Consequently, the larger errors shown in $C p$ for light water at some specific state points such as in the plot at 30 bar do not affect overall results. Specific heat capacity is supplied by equations with fitted coefficients derived from experimentally measured data. It stems from the subroutine taking the derivative of enthalpy to find $C p$. This process is correct as long as the derivative is smooth. There is a break point in the equations for the fit to enthalpy that causes the local error as shown in Figure 2.3. This break point can be avoided and may be corrected in the future. Nevertheless, the code is currently applied in the analyses of research reactors with operation pressures lower than 5 bar. Therefore, the light water properties generated by PARET/ANL are adequate for the current applications.

Table 2.2. Maximum Difference in $\mathrm{H}_{2} \mathrm{O}$ Properties between PARET/ANL and NIST Data

\begin{tabular}{|c|c|c|c|c|c|}
\hline \multirow{2}{*}{$\begin{array}{c}\text { Phase \& } \\
\text { Pressure }\end{array}$} & \multicolumn{5}{|c|}{ Maximum Difference for all Tested Temperatures, \% } \\
\hline & $\boldsymbol{H}$ & $\boldsymbol{k}$ & $\boldsymbol{C} \boldsymbol{\rho}$ & $\boldsymbol{\rho}$ & $\boldsymbol{\mu}$ \\
\hline Liquid, 1 bar & 0.53 & 2.14 & 1.18 & 0.07 & 3.02 \\
\hline Vapor, 1 bar & 0.22 & 0.93 & 3.79 & 0.62 & 1.92 \\
\hline Liquid, 2 bar & 0.52 & 2.06 & 1.07 & 0.10 & 3.59 \\
\hline Vapor, 2 bar & 0.24 & 2.70 & 3.83 & 0.64 & 1.22 \\
\hline Liquid, 5 bar & 0.51 & 2.02 & 1.00 & 0.11 & 3.51 \\
\hline Vapor, 5 bar & 0.26 & 5.08 & 5.29 & 0.68 & 0.65 \\
\hline Liquid, 10 bar & 0.50 & 2.09 & 0.99 & 0.11 & 3.38 \\
\hline Vapor, 10 bar & 1.27 & 5.84 & 14.84 & 4.14 & 0.65 \\
\hline Liquid, 20 bar & 0.46 & 1.97 & 2.99 & 0.11 & 3.09 \\
\hline Vapor, 20 bar & 0.41 & 6.02 & 6.16 & 1.27 & 1.77 \\
\hline Liquid, 30 bar & 0.43 & 1.85 & 14.77 & 0.11 & 3.42 \\
\hline Vapor, 30 bar & 0.09 & 5.11 & 13.26 & 0.23 & 2.90 \\
\hline Liquid, 40 bar & 0.39 & 1.73 & 3.28 & 0.11 & 3.85 \\
\hline Vapor, 40 bar & 0.34 & 3.95 & 17.31 & 0.99 & 4.02 \\
\hline Liquid, 50 bar & 0.36 & 1.67 & 2.98 & 0.11 & 4.05 \\
\hline Vapor, 50 bar & 0.51 & 2.80 & 20.06 & 1.52 & 5.14 \\
\hline Liquid, 75 bar & 0.30 & 1.57 & 2.76 & 0.11 & 4.42 \\
\hline Vapor, 75 bar & 0.64 & 0.82 & 23.43 & 1.99 & 8.04 \\
\hline Liquid, 100 bar & 0.26 & 1.47 & 2.09 & 0.11 & 6.75 \\
\hline Vapor, 100 bar & 0.47 & 3.13 & 23.87 & 1.52 & 10.99 \\
\hline Liquid, 125bar & 0.21 & 1.37 & 1.30 & 0.11 & 14.33 \\
\hline Vapor, 125bar & 0.41 & 4.49 & 17.51 & 0.86 & 14.01 \\
\hline
\end{tabular}




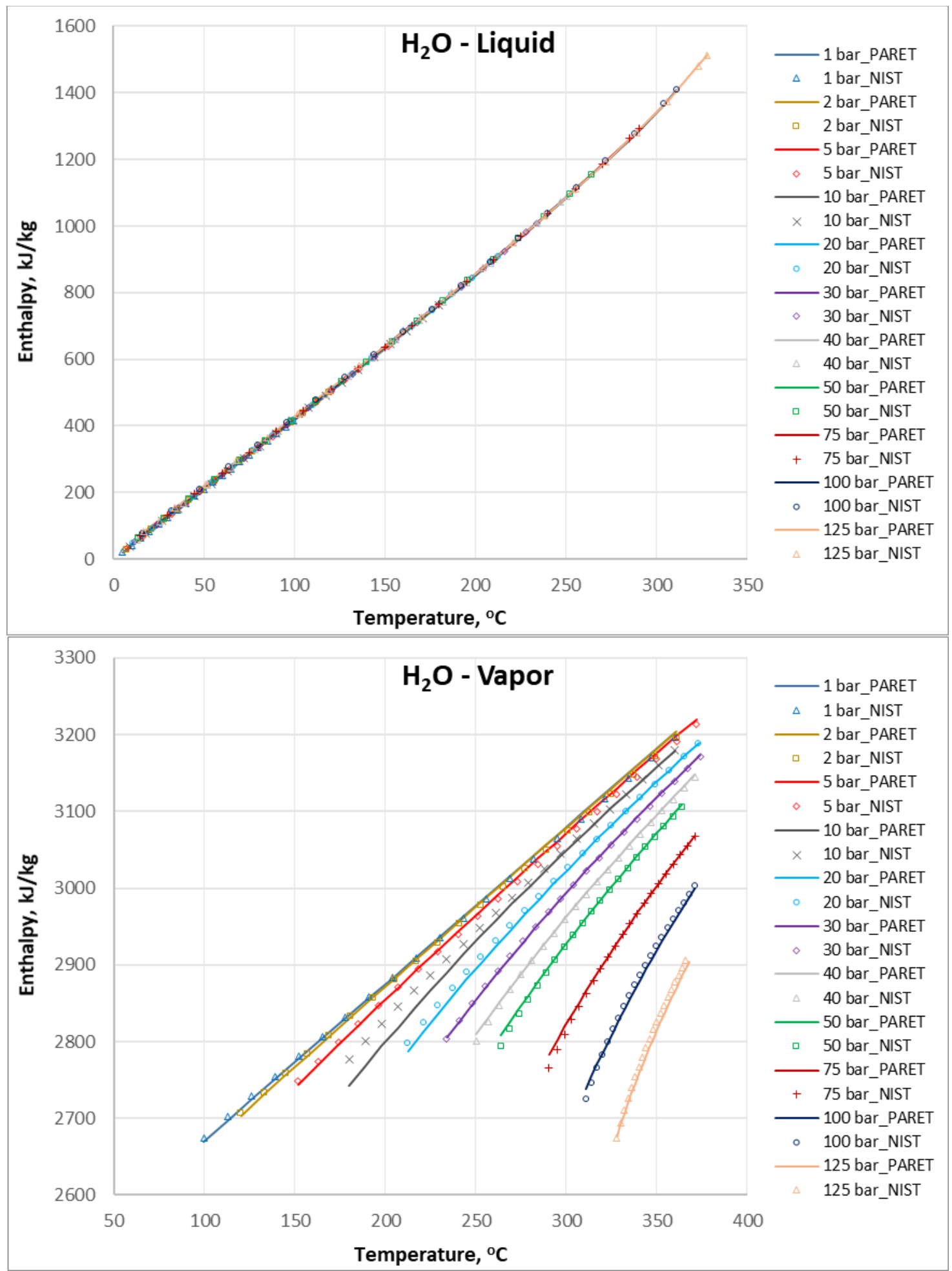

Figure 2.1. Comparison of $\mathrm{H}_{2} \mathrm{O}$ Enthalpy between PARET/ANL and NIST Data 


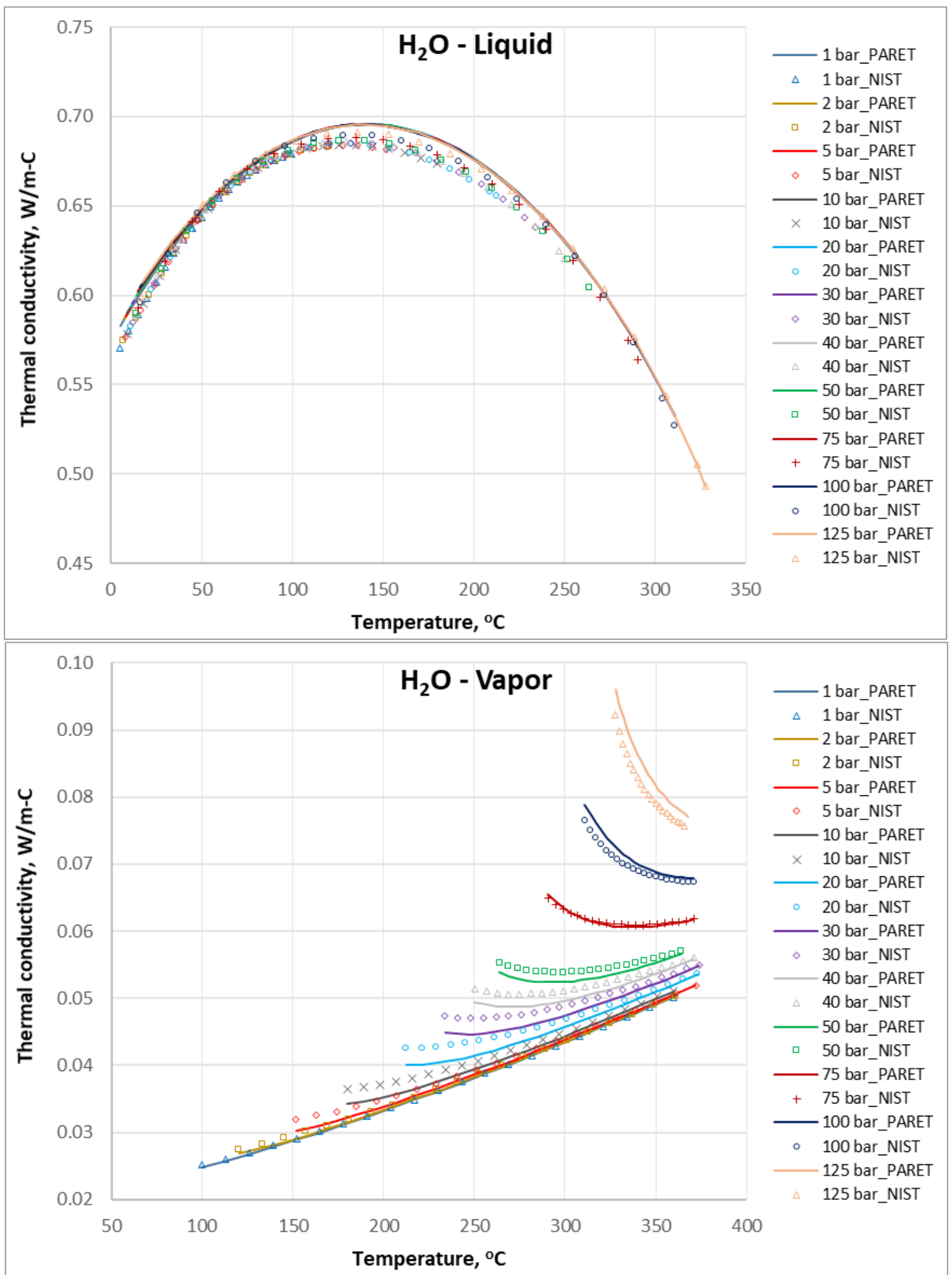

Figure 2.2. Comparison of $\mathrm{H}_{2} \mathrm{O}$ Thermal Conductivity between PARET/ANL and NIST Data 


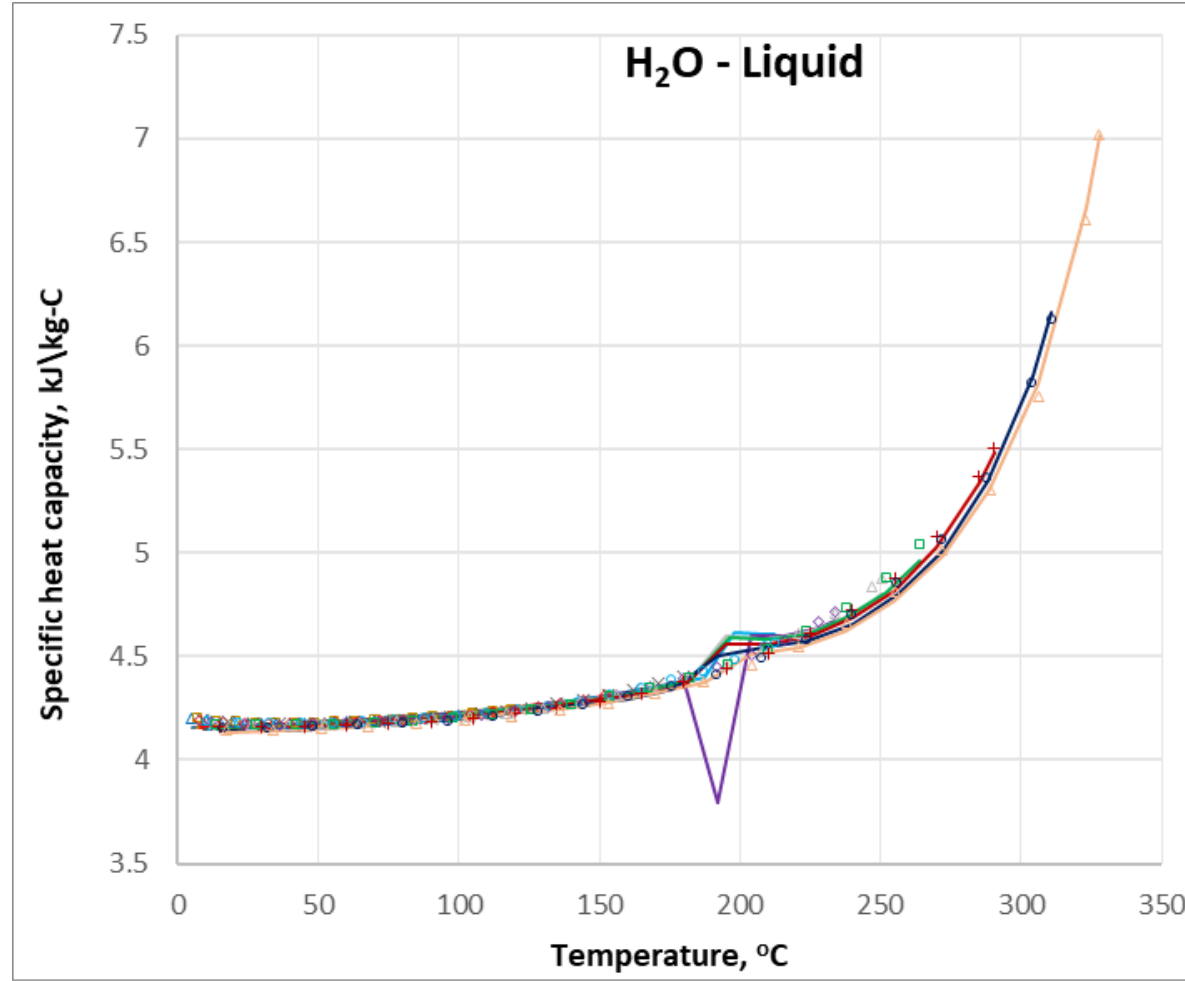

- 1 bar_PARET

$\triangle 1$ bar_NIST

- 2 bar_PARET

- 2 bar_NIST

5 bar_PARET

$\diamond 5$ bar_NIST

10 bar_PARET

$\times 10$ bar_NIST

- 20 bar_PARET

20 bar_NIST

— 30 bar_PARET

- 30 bar_NIST

40 bar_PARET

40 bar_NIST

— 50 bar_PARET

- 50 bar_NIST

— 75 bar_PARET

+ 75 bar_NIST

- 100 bar_PARET

- 100 bar_NIST

125 bar_PARET

125 bar_NIST

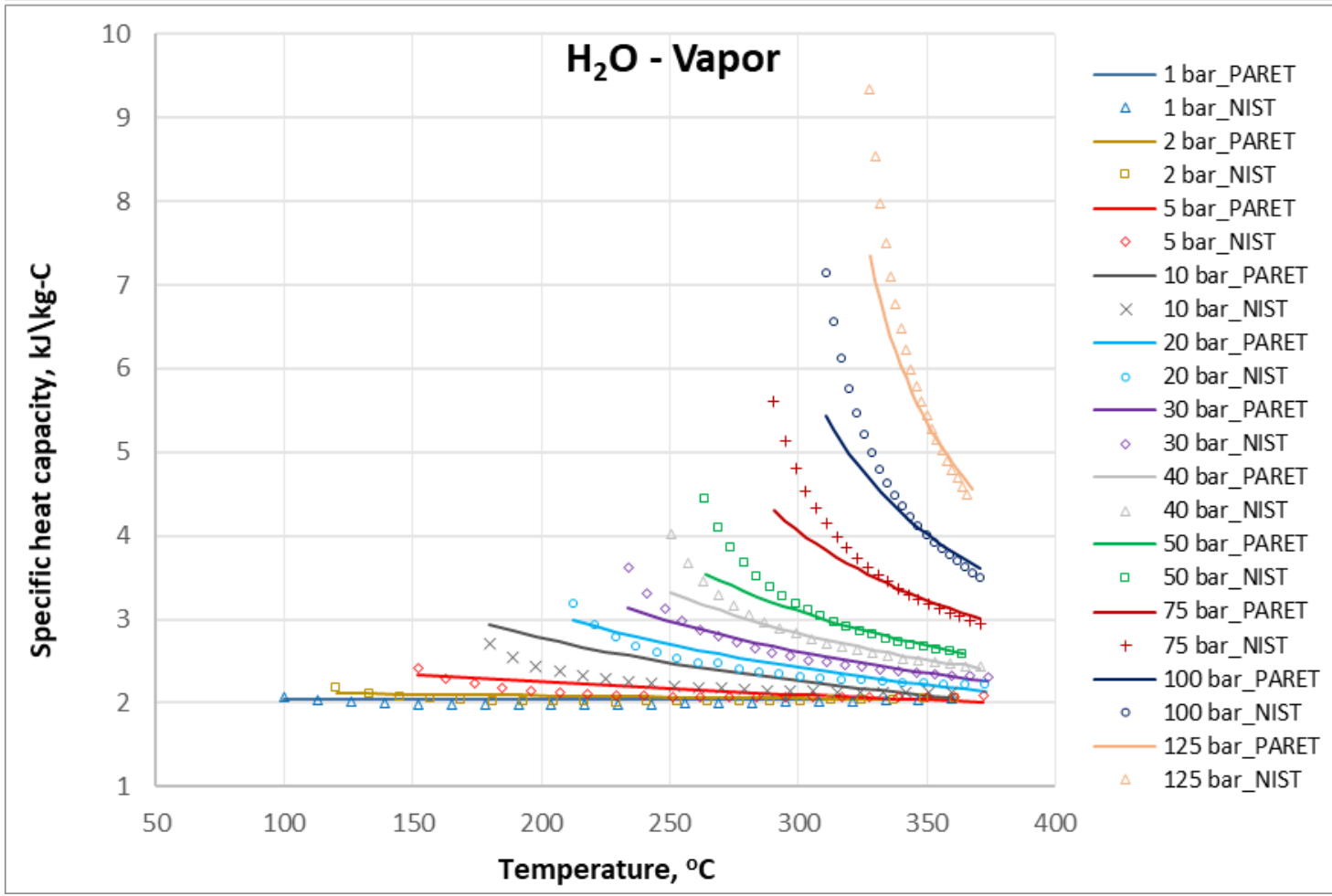

Figure 2.3. Comparison of $\mathrm{H}_{2} \mathrm{O}$ Specific Heat Capacity between PARET/ANL and NIST Data 


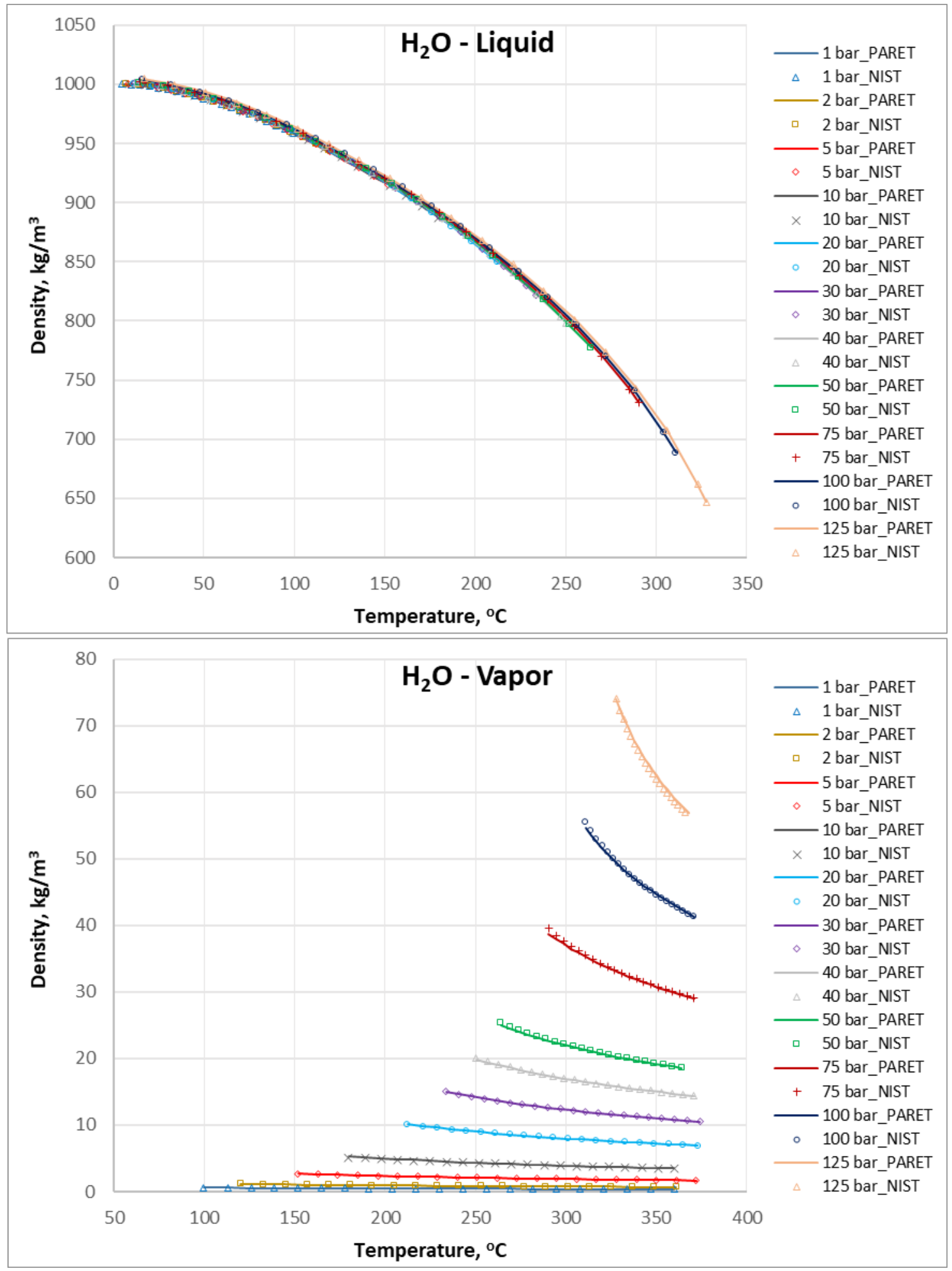

Figure 2.4. Comparison of $\mathrm{H}_{2} \mathrm{O}$ Density between PARET/ANL and NIST Data 


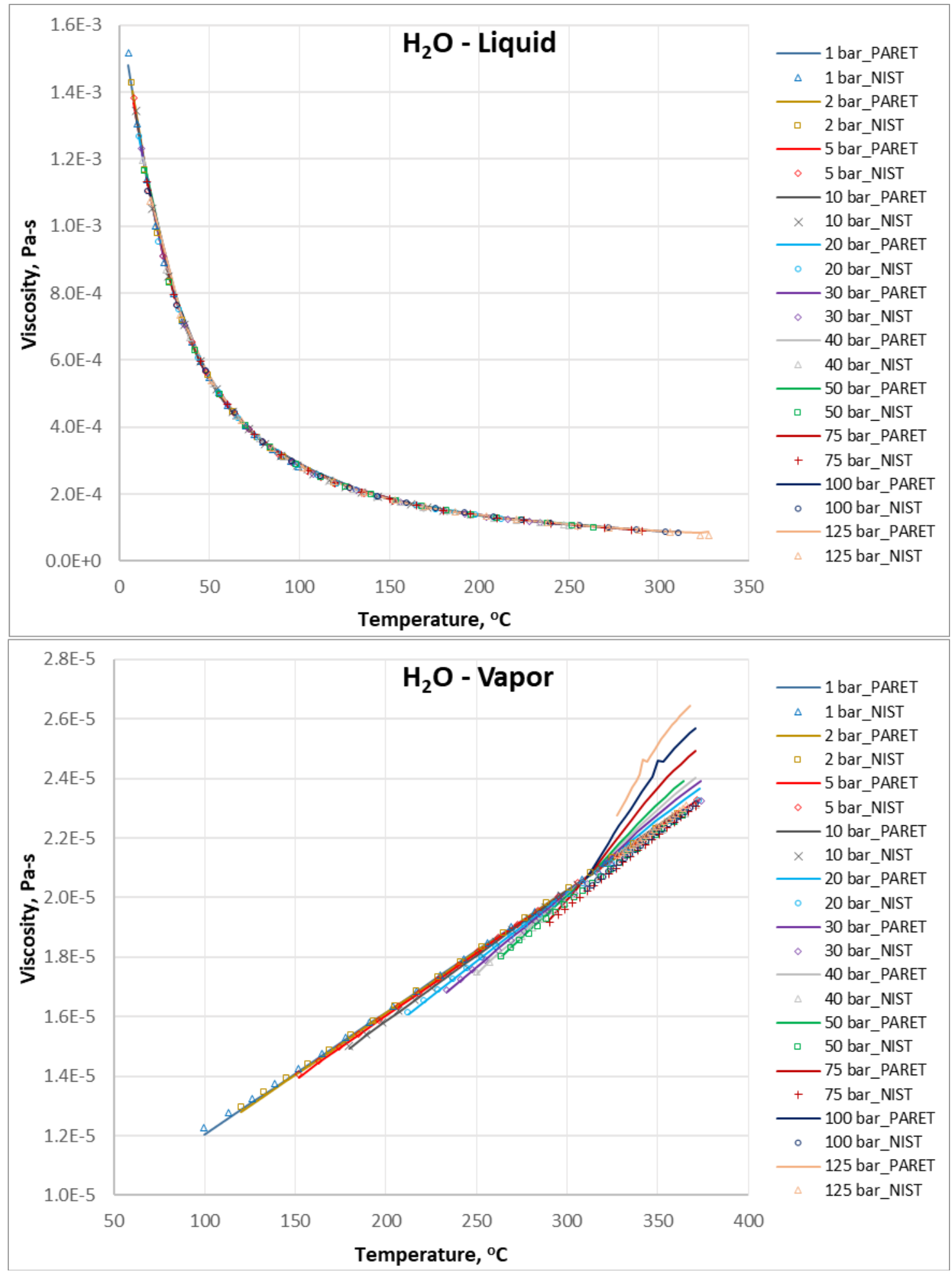

Figure 2.5. Comparison of $\mathrm{H}_{2} \mathrm{O}$ Viscosity between PARET/ANL and NIST Data 


\subsubsection{Heavy Water Properties}

The maximum differences in heavy water properties between PARET/ANL and NIST for all tested temperatures are presented in Table 2.3, while the detailed results for each property are showed in Figure 2.6 to Figure 2.10. It is seen that PARET/ANL results agree quite well with the NIST data for the pressures up to 50 bar. It is concluded that the heavy water properties generated by PARET/ANL are adequate for the current applications to the research and test reactors.

Table 2.3. Maximum difference in $\mathrm{D}_{2} \mathrm{O}$ properties between PARET/ANL and NIST Data

\begin{tabular}{|c|c|c|c|c|c|}
\hline \multirow{2}{*}{$\begin{array}{c}\text { Phase } \boldsymbol{\&} \\
\text { Pressure }\end{array}$} & \multicolumn{5}{|c|}{ Maximum Difference for all Tested Temperatures, \% } \\
\cline { 2 - 6 } & $\boldsymbol{H}$ & $\boldsymbol{K}$ & $\boldsymbol{C} \boldsymbol{P}$ & $\boldsymbol{\rho}$ & $\boldsymbol{\mu}$ \\
\hline Liquid, 1 bar & 2.725 & 1.855 & 3.285 & 0.463 & 1.363 \\
\hline Vapor, 1 bar & 0.284 & 3.613 & 1.098 & 0.021 & 1.892 \\
\hline Liquid, 2 bar & 2.718 & 1.773 & 3.170 & 0.453 & 0.986 \\
\hline Vapor, 2 bar & 0.283 & 3.331 & 0.424 & 0.040 & 2.262 \\
\hline Liquid, 5 bar & 2.724 & 1.533 & 2.882 & 0.412 & 0.622 \\
\hline Vapor, 5 bar & 0.241 & 2.604 & 0.893 & 0.179 & 2.181 \\
\hline Liquid, 10 bar & 2.765 & 1.452 & 2.796 & 0.394 & 0.615 \\
\hline Vapor, 10 bar & 0.160 & 2.147 & 0.877 & 0.412 & 1.556 \\
\hline Liquid, 20 bar & 2.776 & 1.375 & 2.718 & 0.384 & 0.571 \\
\hline Vapor, 20 bar & 0.169 & 1.999 & 2.234 & 0.386 & 1.015 \\
\hline Liquid, 30 bar & 2.791 & 1.298 & 2.646 & 0.371 & 0.629 \\
\hline Vapor, 30 bar & 0.150 & 2.724 & 3.798 & 0.473 & 0.627 \\
\hline Liquid, 40 bar & 2.791 & 1.298 & 2.646 & 0.371 & 0.629 \\
\hline Vapor, 40 bar & 0.150 & 2.724 & 3.798 & 0.473 & 0.627 \\
\hline Liquid, 50 bar & 2.790 & 1.225 & 2.632 & 0.356 & 0.754 \\
\hline Vapor, 50 bar & 0.150 & 2.724 & 3.798 & 0.473 & 0.627 \\
\hline Liquid, 75 bar & 2.805 & 1.146 & 2.621 & 0.338 & 0.823 \\
\hline Vapor, 75 bar & 0.156 & 3.456 & 6.799 & 0.753 & 0.932 \\
\hline Liquid, 100 bar & 2.798 & 1.068 & 2.596 & 0.326 & 0.821 \\
\hline Vapor, 100 bar & 0.248 & 1.328 & 7.704 & 0.927 & 1.310 \\
\hline Liquid, 125 bar & 2.787 & 2.694 & 2.559 & 0.311 & 0.892 \\
\hline Vapor, 125 bar & 0.336 & 1.575 & 8.019 & 1.001 & 1.611 \\
\hline
\end{tabular}



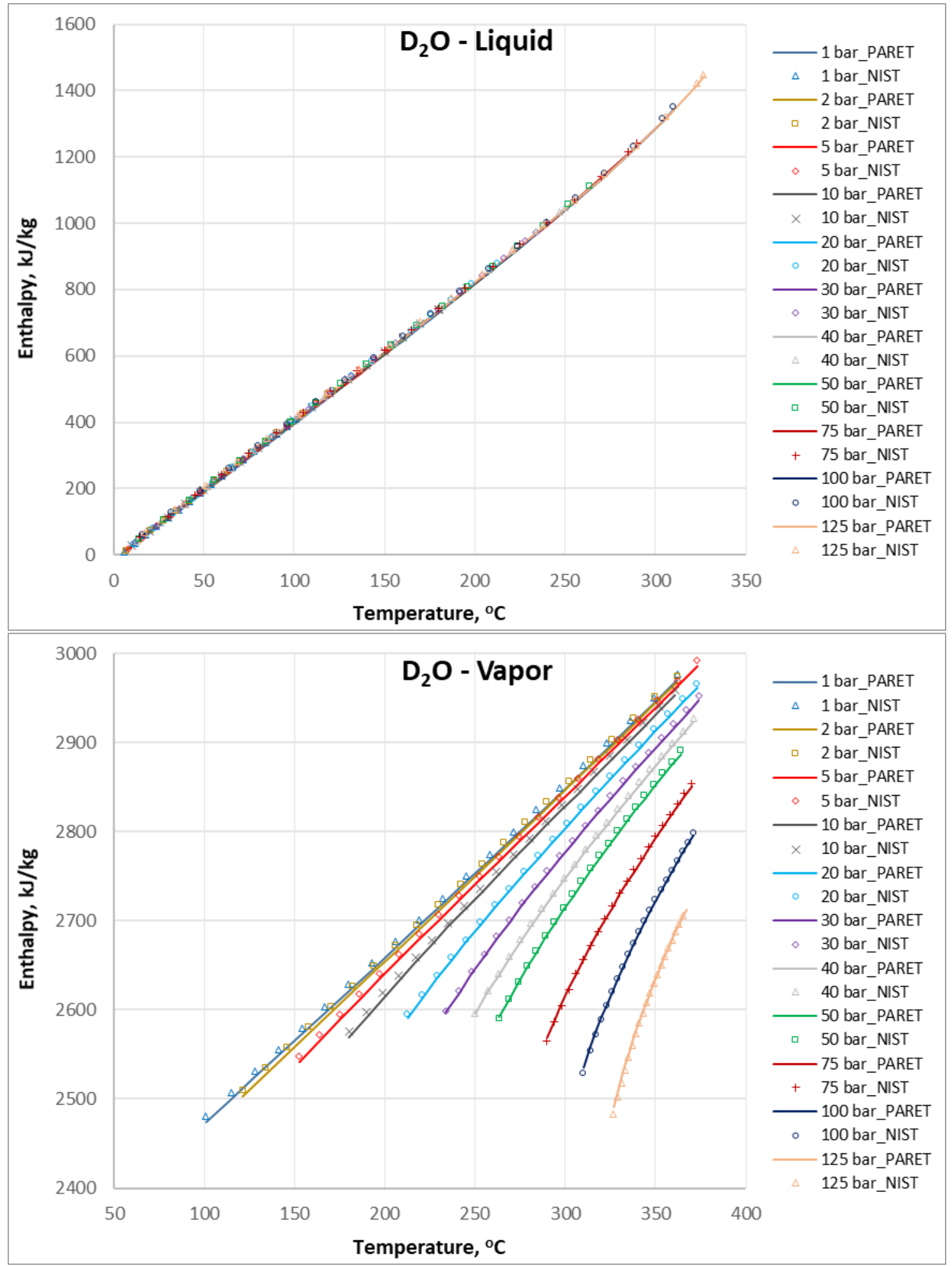

Figure 2.6. Comparison of $\mathrm{D}_{2} \mathrm{O}$ Enthalpy between PARET/ANL and NIST Data 


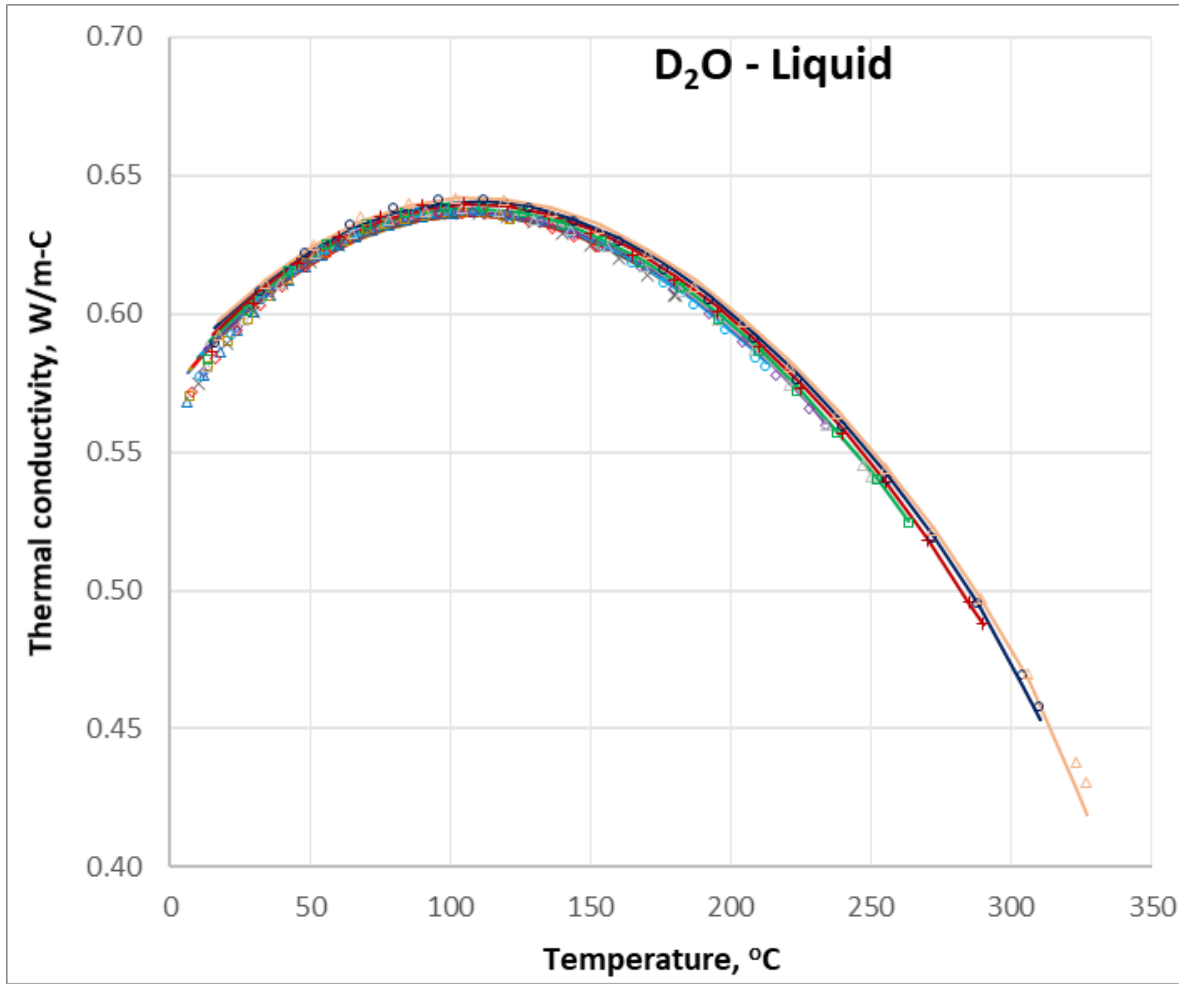

1 bar_PARE

$\triangle 1$ bar_NIST

2 bar_PARET

- 2 bar_NIST

5 bar_PARET

$\checkmark 5$ bar_NIST

10 bar_PARET

$\times 10$ bar_NIST

20 bar_PARET

- 20 bar_NIST

30 bar_PARET

$\checkmark \quad 30$ bar_NIST

40 bar PARET 40 bar_NIST

50 bar_PARET

口 50 bar NIST

75 bar_PARET

+ 75 bar_NIST

- 100 bar_PARET

- 100 bar_NIST 125 bar_PARET 125 bar_NIST

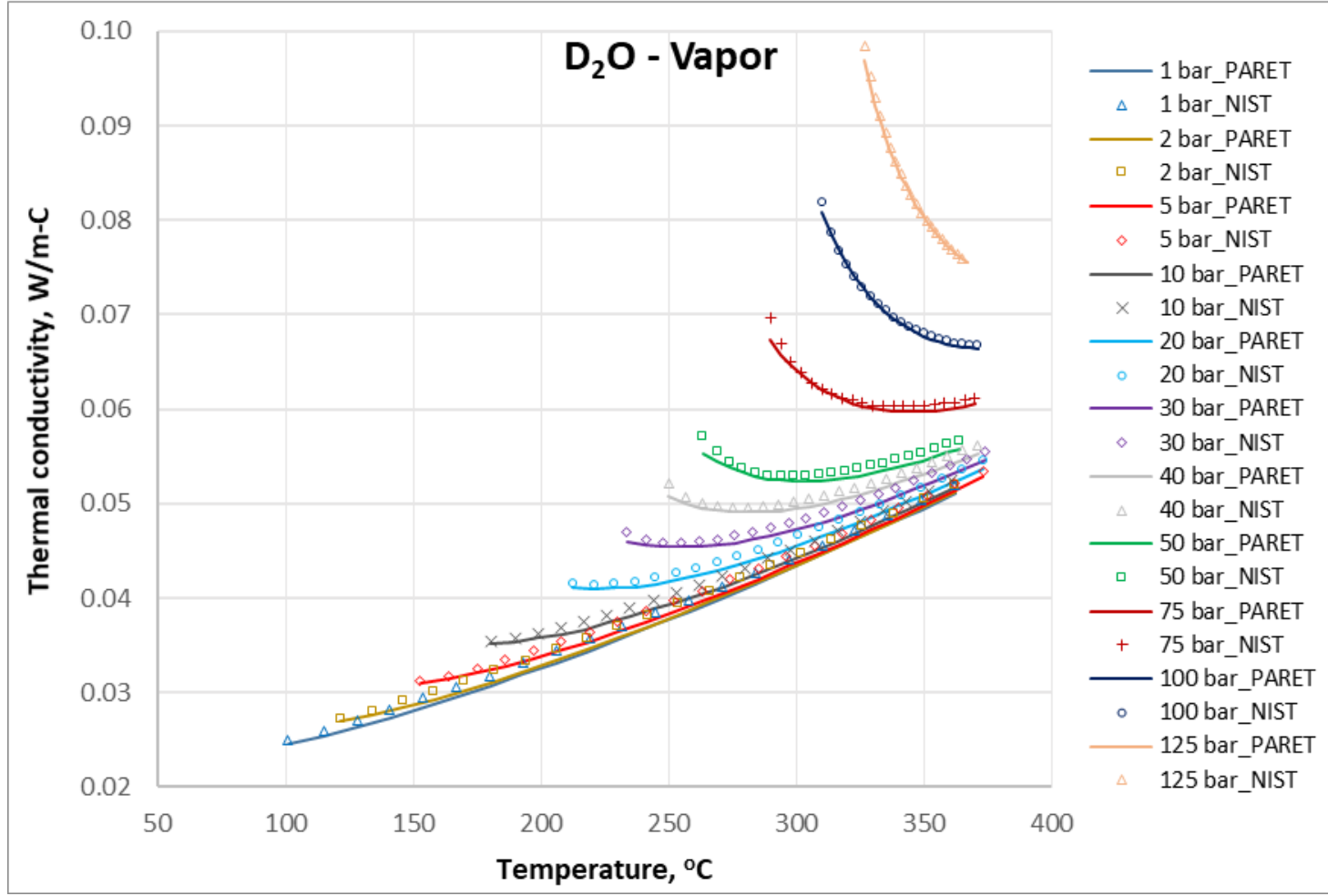

Figure 2.7. Comparison of $\mathrm{D}_{2} \mathrm{O}$ Thermal Conductivity between PARET/ANL and NIST Data 


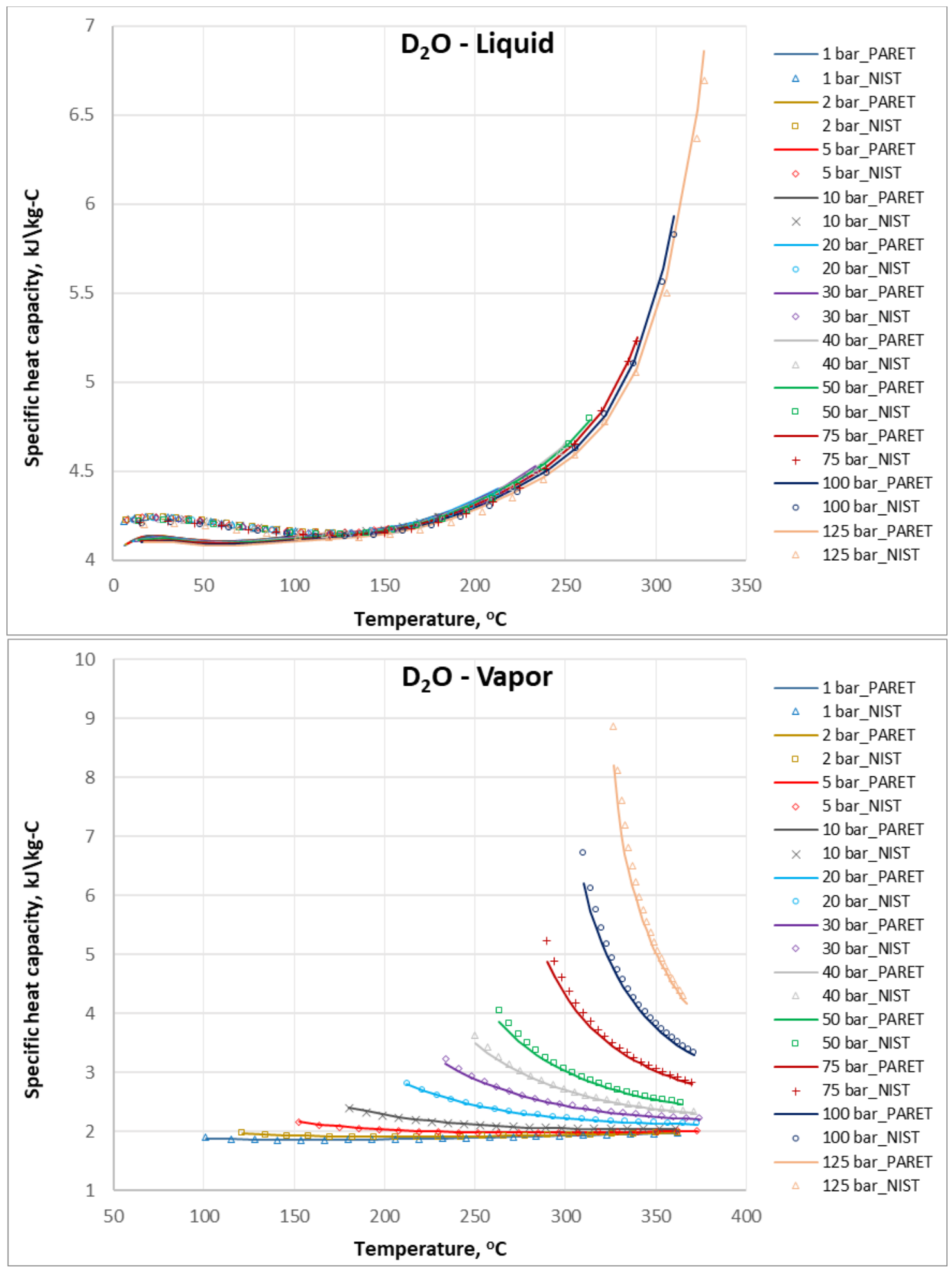

Figure 2.8. Comparison of $\mathrm{D}_{2} \mathrm{O}$ Specific Heat Capacity between PARET/ANL and NIST Data 


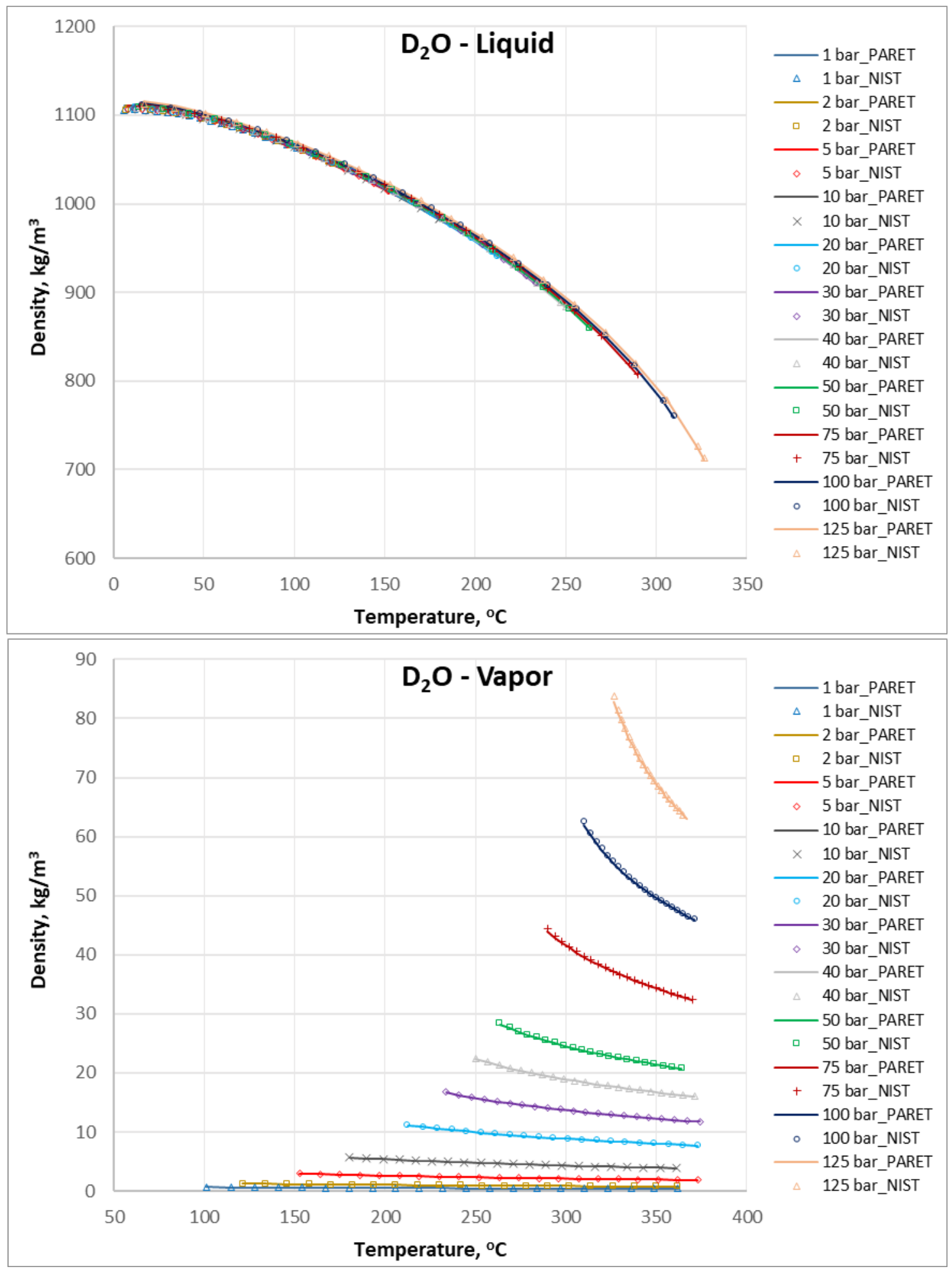

Figure 2.9. Comparison of $\mathrm{D}_{2} \mathrm{O}$ Density between PARET/ANL and NIST Data 


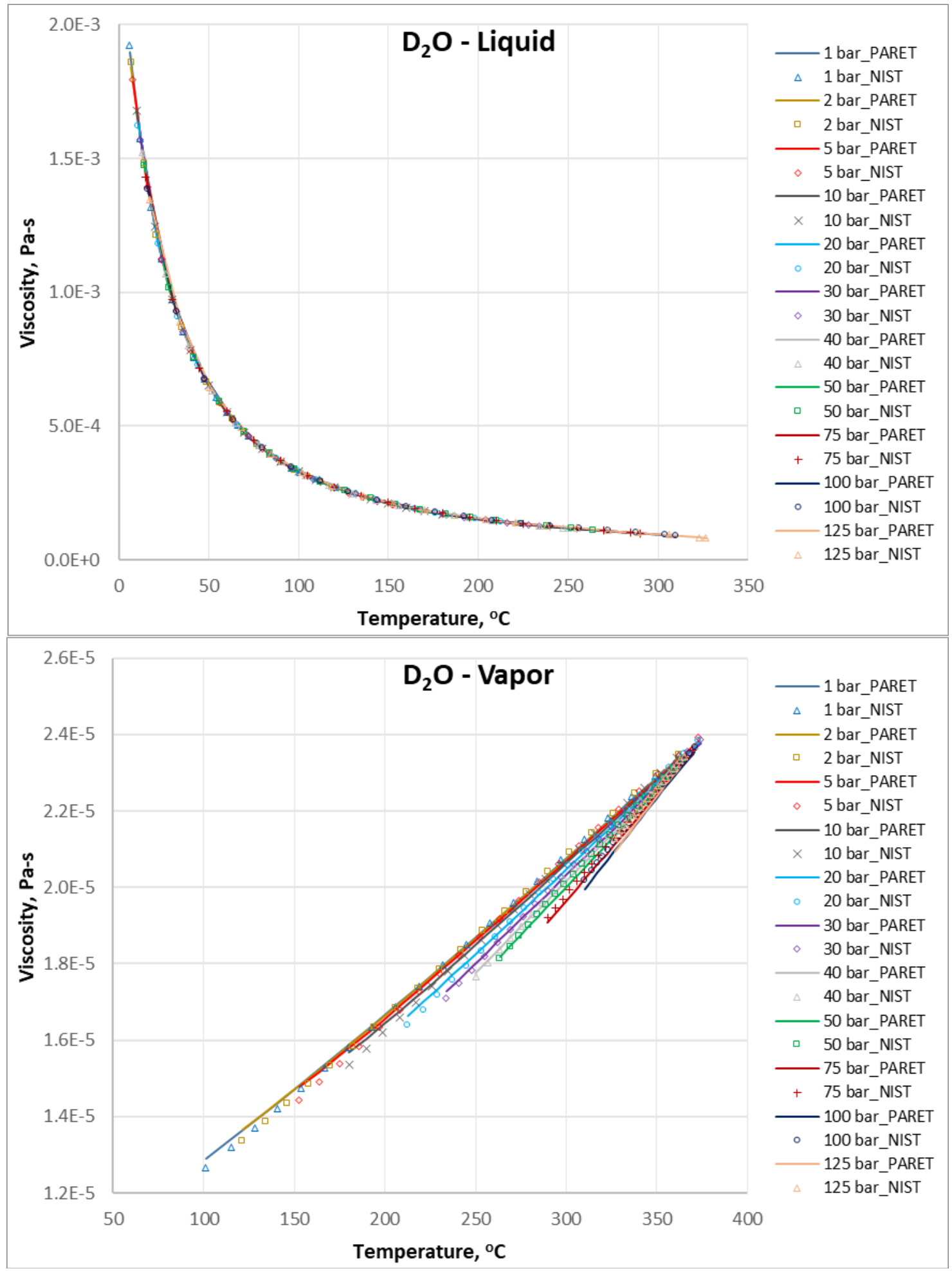

Figure 2.10. Comparison of $\mathrm{D}_{2} \mathrm{O}$ Viscosity between PARET/ANL and NIST Data 


\subsection{Capability A2 - Solid Material Thermal Properties}

PARET/ANL requires input of thermal conductivity $(k)$ and volumetric heat capacity $\left(\rho C_{p}\right)$ in order to model the temperature and energy content everywhere at any time in the solid materials comprising the fuel plate or pin. As indicated by the User Guide Section 5.5.1 [2], both parameters are specified using the following relationship:

$$
\mathrm{X}=\alpha_{1} \mathrm{~T}^{2}+\alpha_{2} \mathrm{~T}+\alpha_{3}+\alpha_{4} \mathrm{~T}^{-1}
$$

where X: thermal conductivity or volumetric heat capacity; T: solid temperature; and $\alpha$ : coefficients.

Verification of this capability is based on a code-to-code comparison between PARET/ANL and RELAP5/MOD3.3 calculations of a power-driven test. Obtained data at steady-state conditions are used to check the material thermal conductivities, while the volumetric heat capacities are evaluated by transient data because there are significant changes in temperatures of fuel and cladding.

Test case A02_01 is selected to represent the fuel used by a typical 12-MW U.S. research reactor that goes through a transient characterized by a given power history of $2.0 \mathrm{sec}$. The relationship between power and transient time (Figure 2.11a) is extracted from previous simulation results for a reactivity insertion scenario in this reactor. The test case consists of two channels (one average channel and one hot channel) having the same axial relative power distribution showed by Figure $2.11 \mathrm{~b}$ and the main input data presented in Table 2.4.
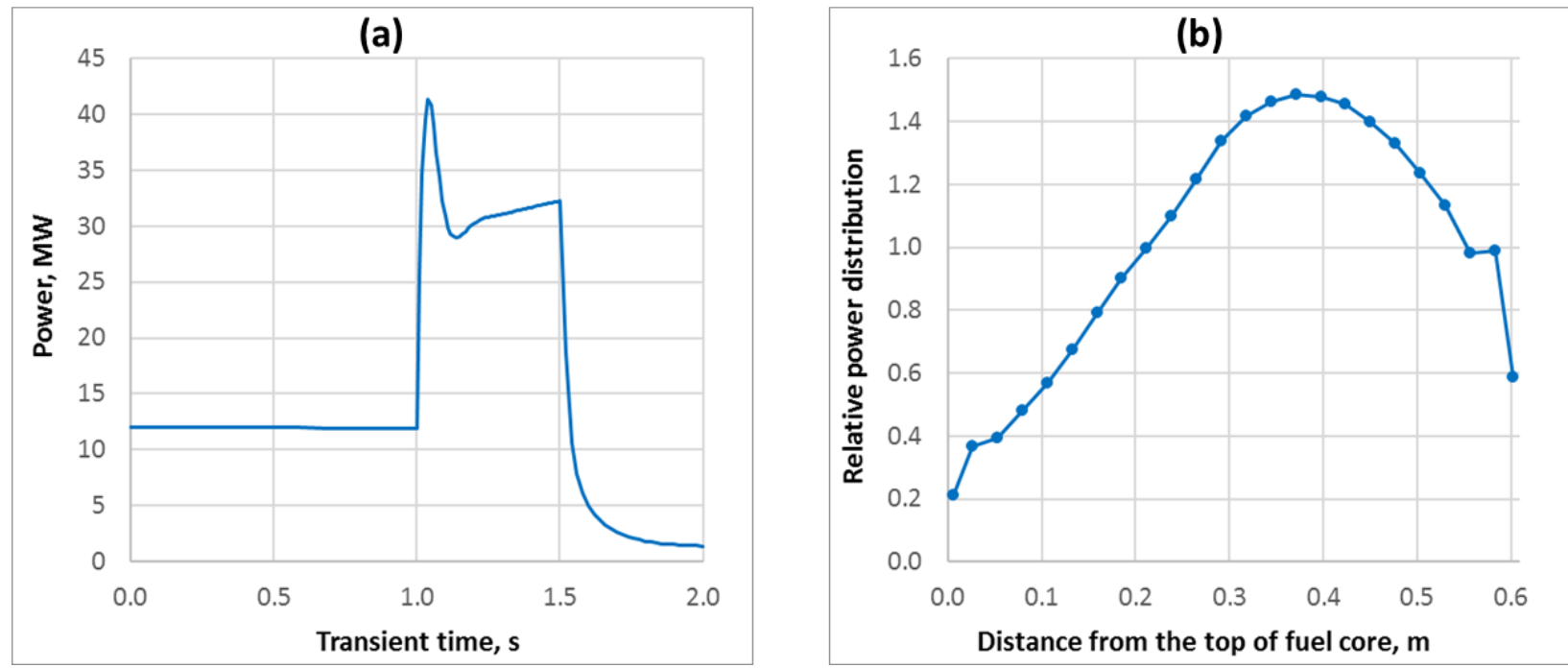

Figure 2.11. Input Data of (a) Power History and (b) Axial Power Distribution 
Table 2.4. Specifications of Test Case A02_01

\begin{tabular}{|c|c|c|c|c|}
\hline \multirow{2}{*}{ Group } & \multirow{2}{*}{\multicolumn{2}{|c|}{ Input Parameters }} & \multicolumn{2}{|c|}{ Channel } \\
\hline & & & Average & Hot \\
\hline \multirow{8}{*}{ Geometry } & \multicolumn{2}{|l|}{ Active fuel length, $\mathrm{m}$} & \multicolumn{2}{|c|}{0.6096} \\
\hline & \multicolumn{2}{|l|}{ Volume of fuel meat, $\mathrm{m}^{3}$} & 7.28400E-02 & 4.99682E-03 \\
\hline & \multicolumn{2}{|l|}{ Fuel thickness, m } & 4.79287E-04 & 4.31800E-04 \\
\hline & \multicolumn{2}{|c|}{ Zirconium thickness (one side), $\mathrm{m}$} & \multicolumn{2}{|c|}{$2.54000 \mathrm{E}-05$} \\
\hline & \multicolumn{2}{|c|}{ Clad thickness (one side), $\mathrm{m}$} & 2.96517E-04 & $3.81000 E-04$ \\
\hline & \multicolumn{2}{|c|}{ Oxide thickness (one side), $\mathrm{m}$} & $1.49860 \mathrm{E}-05$ & $1.00000 \mathrm{E}-10$ \\
\hline & \multicolumn{2}{|l|}{ Coolant flow area, $\mathrm{m}$} & 3.25933E-02 & 1.19778E-05 \\
\hline & \multicolumn{2}{|c|}{ Channel hydraulic diameter, $\mathrm{m}$} & 4.49820E-03 & 4.57160E-03 \\
\hline \multirow{3}{*}{$\begin{array}{c}\text { Flow } \\
\text { condition }\end{array}$} & \multicolumn{2}{|l|}{ Coolant flowrate, $\mathrm{kg} / \mathrm{s}$} & $2.17812 E+02$ & $8.00250 E-02$ \\
\hline & \multicolumn{2}{|l|}{ Inlet temperature, ${ }^{\circ} \mathrm{C}$} & \multicolumn{2}{|c|}{$5.44000 E+01$} \\
\hline & \multicolumn{2}{|l|}{ Outlet pressure, $\mathrm{Pa}$} & \multicolumn{2}{|c|}{$4.39000 E+05$} \\
\hline \multirow{8}{*}{$\begin{array}{l}\text { Material } \\
\text { thermal } \\
\text { property }\end{array}$} & \multirow{4}{*}{$\begin{array}{l}\text { Thermal conductivity, } \\
\mathrm{W} / \mathrm{m}^{*} \mathrm{~K} \\
\text { (Temperature } \mathrm{T} \text { is in } \\
\text { Kelvin) }\end{array}$} & Fuel meat & $11.0+0.025 * \mathrm{~T}$ & $14.0+0.030 * T$ \\
\hline & & Zirconium & \multicolumn{2}{|c|}{$9.0+0.007 * \mathrm{~T}$} \\
\hline & & Cladding & \multicolumn{2}{|c|}{$150.0+0.18 * \mathrm{~T}-0.00025 * \mathrm{~T}^{2}$} \\
\hline & & Oxide & \multicolumn{2}{|c|}{2.25} \\
\hline & \multirow{4}{*}{$\begin{array}{l}\text { Rho* } \mathrm{Cp}, \mathrm{J} / \mathrm{m}^{3 *} \mathrm{~K} \\
\text { (Temperature } \mathrm{T} \text { is in } \\
\text { Kelvin) }\end{array}$} & Fuel meat & \multicolumn{2}{|c|}{$2.0 \mathrm{E} 6+1200 * \mathrm{~T}$} \\
\hline & & Zirconium & \multicolumn{2}{|c|}{$1.8 \mathrm{E}+6+700 * \mathrm{~T}$} \\
\hline & & Cladding & \multicolumn{2}{|c|}{ 4.3E+6-2700*T+2.2* $\mathrm{T}^{2}$} \\
\hline & & Oxide & \multicolumn{2}{|c|}{1.00} \\
\hline \multirow{2}{*}{ Power } & \multicolumn{2}{|c|}{ Total steady-state core power, MW } & \multicolumn{2}{|c|}{12.0} \\
\hline & \multicolumn{2}{|c|}{ Channel power distribution, $\%$} & 99.9326 & 0.0674 \\
\hline
\end{tabular}


It should be noticed that there are differences in the meshing systems used by the RELAP5 and PARET/ANL codes as well as in the locations at which the temperatures are reported. As can be seen in Figure 2.12a, PARET/ANL has an optimized solid and coolant nodalization in which the temperatures are calculated at the center of solid nodes and at the boundary of coolant nodes. In this figure, $\mathrm{T}$ stands for temperature and $\mathrm{P}$ stands for power density. In contrast, the RELAP5 calculations use the temperatures at the outlet of both solid and coolant nodes. Therefore, in order to enable a direct code-to-code comparison, the fuel plate in RELAP5 model is discretized as shown in Figure $2.12 \mathrm{~b}$ so that the temperatures $\mathrm{T}_{2}, \mathrm{~T}_{4}, \mathrm{~T}_{6} \ldots$ correspond to the temperatures $\mathrm{T}_{2}, \mathrm{~T}_{3}, \mathrm{~T}_{4} \ldots$ reported by the PARET/ANL model.

PARET

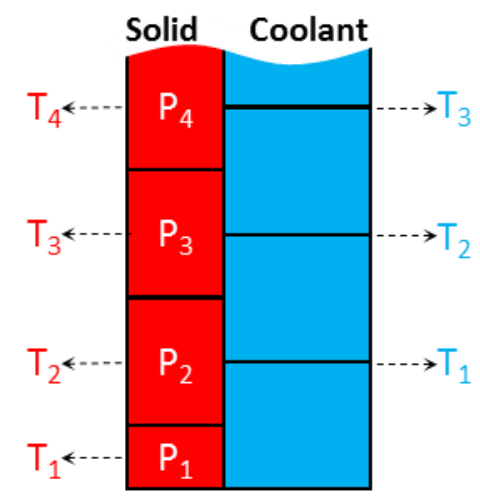

(a)
RELAP5

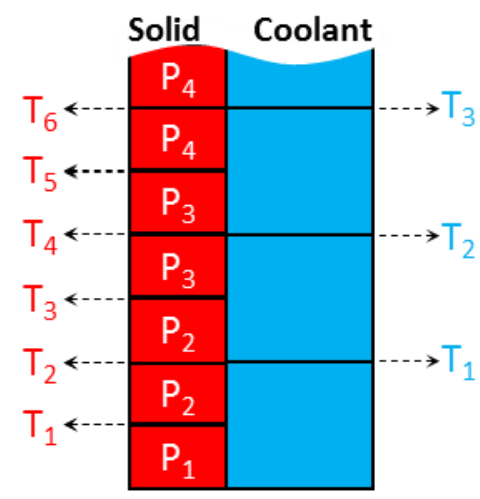

(b)

Figure 2.12. Axial Meshing Systems of (a) PARET/ANL and (b) RELAP5 Codes

The implementation of solid material thermal conductivity is evaluated by comparing steady-state data obtained from PARET/ANL to the same data from RELAP5/MOD3.3. The detailed axial profiles of all important thermal hydraulics parameters at $0.9 \mathrm{sec}$ are considered. Figure 2.13 shows excellent agreement between the steady-state data for both average and hot channels. This agreement verifies that the PARET/ANL code has implemented the temperature-dependent thermal properties correctly.

In order to evaluate the implementation of volumetric heat capacity, results obtained during the transient are compared. Specifically, the peak temperatures of the fuel, clad, and coolant are compared at many time steps. Notice that PARET/ANL calculates the peak temperature as the maximum of all axial nodes and prints it out as an output parameter, while RELAP5 does not. Therefore, an Excel spread sheet is used to calculate the peak temperature from the RELAP5 output data at every time step. As can be seen in Figure 2.14, there is excellent agreement between the transient temperature data for the average channel. The same data obtained data for the hot channel show differences of up to $3.7^{\circ} \mathrm{C}$ in the peak temperatures (Table 2.5). These differences, however, are considered acceptable because the heat transfer mode in the hot channel is changed from singlephase liquid to the more complicated subcooled nucleate boiling at $\sim 1.03 \mathrm{sec}$. 


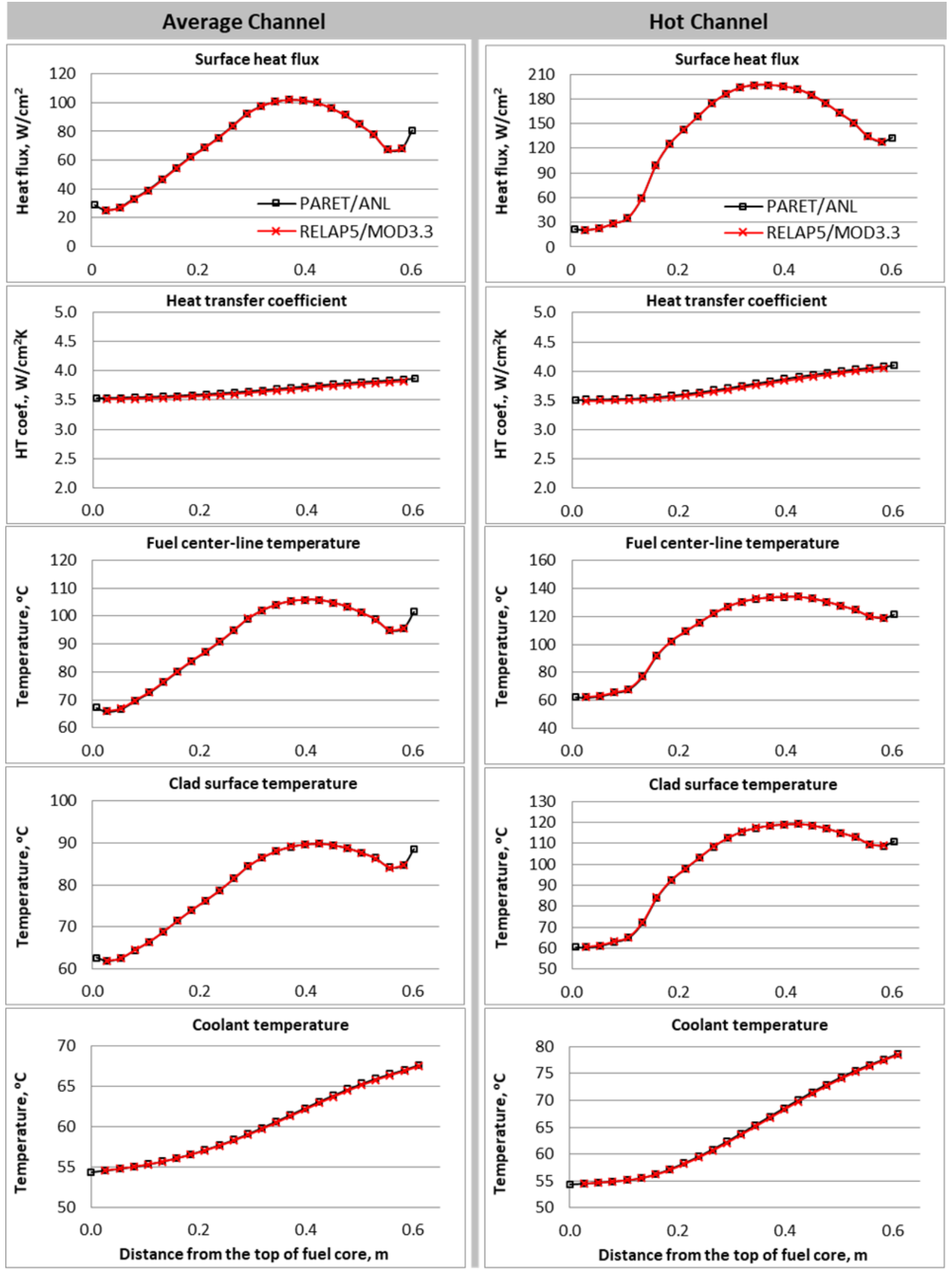

Figure 2.13. Comparison of Steady-State Data 

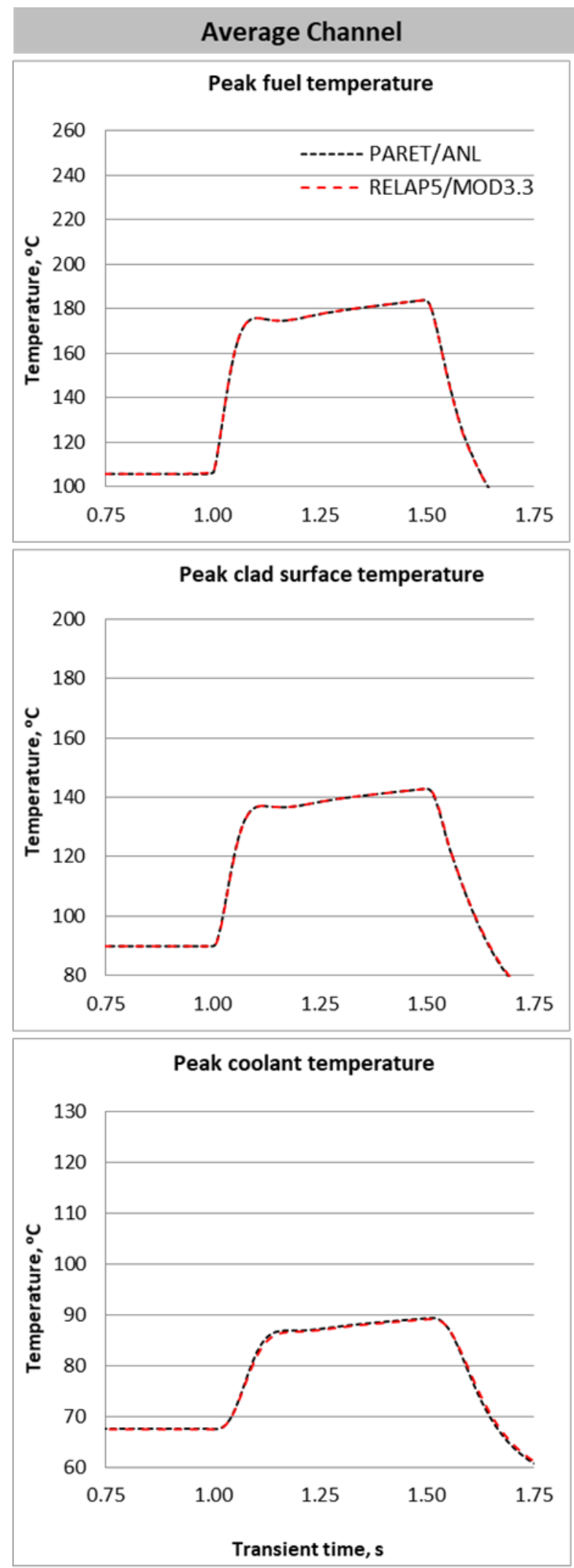

Hot Channel

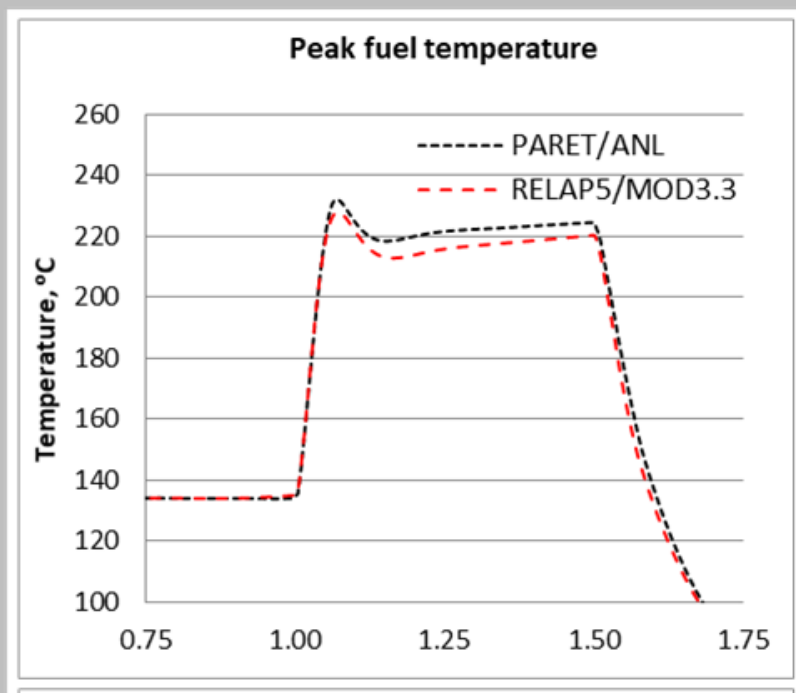

Peak clad surface temperature
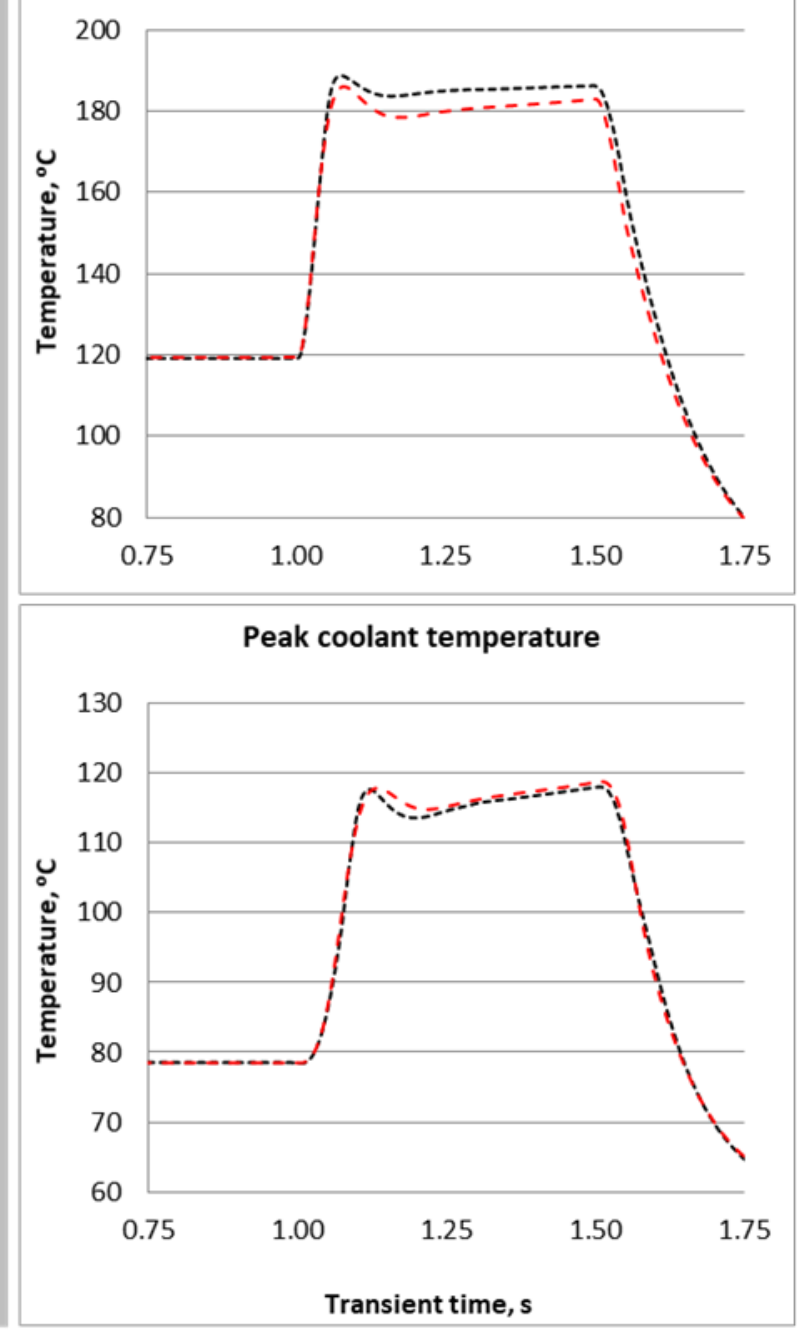

Figure 2.14. Comparison of Transient Data 
Table 2.5. Comparison of Transient Park Temperatures

\begin{tabular}{|l|l|c|c|}
\hline \multicolumn{2}{|l|}{ Peak Temperature, ${ }^{\circ} \mathbf{C}$} & PARET/ANL & RELAP5/MOD3.3 \\
\hline \multirow{2}{*}{ Fuel meat } & Average & 184.0 & 184.2 \\
\cline { 2 - 4 } & Hot & 231.8 & 228.1 \\
\hline \multirow{2}{*}{ Cladding } & Average & 142.8 & 142.9 \\
\cline { 2 - 4 } & Hot & 188.9 & 186.0 \\
\hline \multirow{2}{*}{ Coolant } & Average & 89.4 & 89.1 \\
\cline { 2 - 4 } & Hot & 118.0 & 118.9 \\
\hline
\end{tabular}

\subsection{Capability A3 - Geometry Options}

PARET/ANL has three geometry options regarding the type of fueled components that can be analyzed:

- Fuel in the form of plates, all having the same dimensions and materials (IGEOM=0),

- Fuel in the form of pins, all having the same dimensions and materials (IGEOM=1),

- Fuel in the form of plates with some optional variability for the dimensions and composition of each channel (IGEOM=2).

A channel consists of a single fuel element (rod or plate) together with associated coolant on each side (if a plate) or surrounding it (if a rod). It is generally necessary and reasonable to simplify the analysis of reactor transients by clustering fuel elements of the same physical dimensions and at nominally the same average power density to be represented as a single channel. The point of the IGEOM=2 option is to enable different channels to be unique in certain aspects of their geometry and/or composition. For example, two channels may be identical except that the average burnup is unique in each one. Alternatively, the cladding materials may differ. Or the radial dimensions of meat, gap, clad, and crud layer may be unique. The code can model up to 120 channels.

To initialize the solution, the code first analyzes the geometry and power profiles given. It then predicts how the given power distributions allocate power to the various channels. The next step is to perform a null transient to achieve convergence for the full thermal solution in each fuel plate and in each coolant channel. That process yields an edit of the power supplied to the coolant. That power is compared to the power expected from the point kinetics equations solution at time zero. If the two powers disagree beyond some tolerance, it is reasonable to expect that some error in geometry or power density exists in the input file.

Verification is performed for each geometry option (IGEOM) as follows:

\subsubsection{Fuel Plate (IGEOM = 0)}

Test case A03_01 is set up using the geometry shown in Figure 2.15 and a flat axial power distribution. This test model consist of two classes of channels which together represent a full core: the first class has three identical channels and the second class has one channel with the same fuel and cladding thicknesses but a coolant channel with half thickness. 


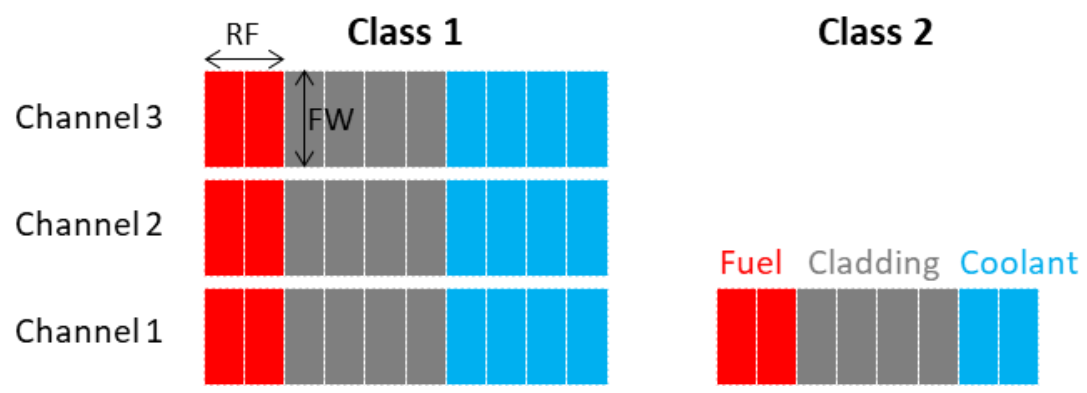

Figure 2.15. Cross-Section of Test Model Using IGEOM= 0

To simplify the hand calculation process, the input parameters (Table 2.6) are determined with the following constraints:

- Same power deposited to each channel: $\quad$ POWER1 $=3 *$ POWER2

- Same heat flux at all plate surfaces:

$\mathrm{PFQ} 1=\mathrm{PFQ} 2$

Table 2.6. Input Parameters of Test Problem with IGEOM = 0

\begin{tabular}{|l|c|c|}
\hline Model power, $\mathrm{MW}$ & \multicolumn{2}{|c|}{1.0} \\
\hline Total fuel volume, $\mathrm{m}^{3}$ & \multicolumn{2}{|c|}{0.00192} \\
\hline Active fuel length, $\mathrm{m}$ & \multicolumn{2}{|c|}{0.6} \\
\hline Coolant mass flux, $\mathrm{kg} / \mathrm{m}^{2} \mathrm{~s}$ & \multicolumn{2}{|c|}{10000} \\
\hline Inlet coolant temperature, ${ }^{\circ} \mathrm{C}$ & \multicolumn{2}{|c|}{20.0} \\
\hline Fuel half thickness (RF), $\mathrm{mm}$ & \multicolumn{2}{|c|}{8.0} \\
\hline Clad thickness, $\mathrm{mm}$ & \multicolumn{2}{|c|}{0.1} \\
\hline Channel fuel width (FW), $\mathrm{m}$ & Class 1 & Class 2 \\
\hline & 3 & 1 \\
\hline Number of channels & 8.0 & 4.0 \\
\hline Coolant half thickness, $\mathrm{mm}$ & 0.75 & 0.25 \\
\hline Fuel volume fraction (BM) & 1.000 & 1.000 \\
\hline Axial source description for all node (PFQ) & & \\
\hline
\end{tabular}


Table 2.7. Comparison between Hand and PARET/ANL Calculations with IGEOM $=0$

\begin{tabular}{|c|c|c|c|c|c|c|}
\hline \multirow{2}{*}{\multicolumn{2}{|c|}{ Calculated Data }} & \multicolumn{2}{|c|}{ Class 1} & \multicolumn{2}{|c|}{ Class 2} & \multirow{3}{*}{$\begin{array}{c}\text { Full Core } \\
1.0\end{array}$} \\
\hline & & \multirow{2}{*}{$\begin{array}{c}\text { Channel } \\
0.25 \\
\end{array}$} & \multirow{2}{*}{$\begin{array}{l}\text { Class } \\
0.75 \\
\end{array}$} & \multirow{2}{*}{$\begin{array}{c}\text { Channel } \\
0.25\end{array}$} & \multirow{2}{*}{$\begin{array}{l}\text { Class } \\
0.25 \\
\end{array}$} & \\
\hline Channol nower MW & Hand & & & & & \\
\hline cnanner power, IVIv & PARET & 0.25 & 0.75 & 0.25 & 0.25 & 1.0 \\
\hline \multirow{2}{*}{ Flowrate, kg/s } & Hand & 16.0 & 48.0 & 8.0 & 8.0 & 56.0 \\
\hline & PARET & 16.0 & 48.0 & 8.0 & 8.0 & 56.0 \\
\hline \multirow{2}{*}{$\begin{array}{l}\text { Coolant temperature } \\
\text { rise, }{ }^{\circ} \mathrm{C}\end{array}$} & Hand & 3.737 & & 7.474 & & \\
\hline & PARET & 3.753 & & 7.504 & & \\
\hline \multirow{2}{*}{$\begin{array}{l}\text { Surface heat flux, } \\
\mathrm{MW} / \mathrm{m}^{2}\end{array}$} & Hand & 2.083 & & 2.083 & & \\
\hline & PARET & 2.083 & & 2.083 & & \\
\hline
\end{tabular}

The obtained results presented in Table 2.7 show a very good agreement between PARET/ANL and hand calculations. Therefore, it is confirmed that the geometry option IGEOM $=0$ works correctly.

\subsubsection{Fuel Rod (IGEOM = 1)}

Test case A03_02 is set up using the geometry shown in Figure 2.16 and a flat axial power distribution. This test model consist of two classes of channels which together represent a full core: the first class has three identical channels and the second class has one channel with the same fuel and clad radii but a coolant channel with half thickness .

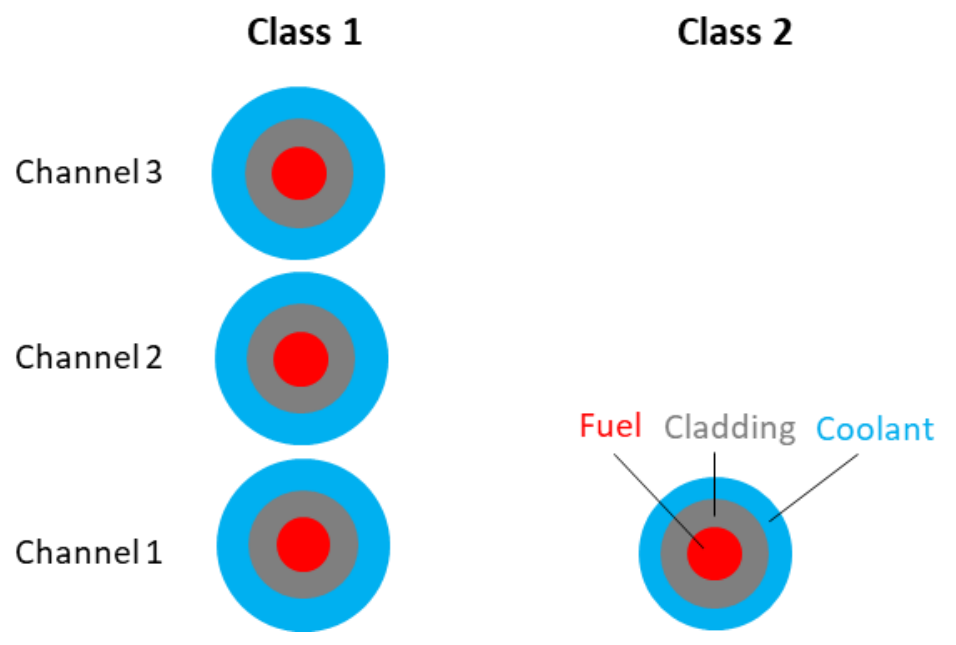

Figure 2.16. Cross-Section of Test Model Using IGEOM = 1

To simplify the hand calculation process, the input parameters (Table 2.8) are determined with the following constraints:

- Same power deposited to each channel:

- Same heat flux at all pin surfaces:
POWER1 $=3 *$ POWER2

PFQ1 $=$ PFQ2 
Table 2.8. Input Parameters of Test Problem with IGEOM = 1

\begin{tabular}{|l|c|c|}
\hline Model power, $\mathrm{MW}$ & \multicolumn{2}{|c|}{0.2} \\
\hline Total fuel volume, $\mathrm{m}^{3}$ & \multicolumn{2}{|c|}{$4.825 \mathrm{E}-04$} \\
\hline Active fuel length, $\mathrm{m}$ & \multicolumn{2}{|c|}{0.6} \\
\hline Coolant mass flux, $\mathrm{kg} / \mathrm{m}^{2} \mathrm{~s}$ & \multicolumn{2}{|c|}{10000} \\
\hline Inlet coolant temperature, $^{\circ} \mathrm{C}$ & \multicolumn{2}{|c|}{20} \\
\hline Fuel radius, $\mathrm{mm}$ & \multicolumn{2}{|c|}{8} \\
\hline Clad thickness, $\mathrm{mm}$ & \multicolumn{2}{|c|}{0.2} \\
\hline Model power, $\mathrm{MW}$ & Class 1 & Class 2 \\
\hline & 3 & 1 \\
\hline Number of channels & 4 & 2 \\
\hline Coolant thickness, $\mathrm{mm}$ & 0.75 & 0.25 \\
\hline Fuel volume fraction (BM) & 1 & 1 \\
\hline Axial source description for all node (PFQ) & \multicolumn{2}{|c|}{8} \\
\hline
\end{tabular}

Table 2.9. Comparison between Hand and PARET/ANL Calculations with IGEOM $=0$

\begin{tabular}{|c|c|c|c|c|c|c|}
\hline \multirow{2}{*}{\multicolumn{2}{|c|}{ Calculated Data }} & \multicolumn{2}{|c|}{ Class 1} & \multicolumn{2}{|c|}{ Class 2} & \multirow{2}{*}{$\begin{array}{l}\text { Full } \\
\text { Core }\end{array}$} \\
\hline & & Channel & Class & Channel & Class & \\
\hline \multirow{2}{*}{ Channel power, MW } & Hand & 0.05 & 0.15 & 0.05 & 0.05 & 0.2 \\
\hline & PARET & 0.05 & 0.15 & 0.05 & 0.05 & 0.2 \\
\hline \multirow{2}{*}{ Flowrate, $\mathrm{kg} / \mathrm{s}$} & Hand & 3.519 & 10.556 & 1.634 & 1.634 & 12.189 \\
\hline & PARET & 3.519 & 10.555 & 1.634 & 1.634 & 12.188 \\
\hline \multirow{2}{*}{ Coolant temperature rise, ${ }^{\circ} \mathrm{C}$} & Hand & 3.399 & & 7.320 & & \\
\hline & PARET & 3.414 & & 7.350 & & \\
\hline \multirow{2}{*}{ Surface heat flux, $\mathrm{MW} / \mathrm{m}^{2}$} & Hand & 1.105 & & 1.105 & & \\
\hline & PARET & 1.105 & & 1.105 & & \\
\hline
\end{tabular}

The obtained results presented in Table 2.9 show a very good agreement between PARET/ANL and hand calculations. Therefore, it is confirmed that the geometry option IGEOM = 1 works correctly.

\subsubsection{Fuel Plate with Different Channel Geometries (IGEOM = 2)}

Test case A03_03 is set up using the geometry shown in Figure 2.17 and a flat axial power distribution. This test model consists of two classes of channels which together represent a full core: the first class has three identical channels and the second class has one channel with different radial dimensions for fuel, clad and coolant.

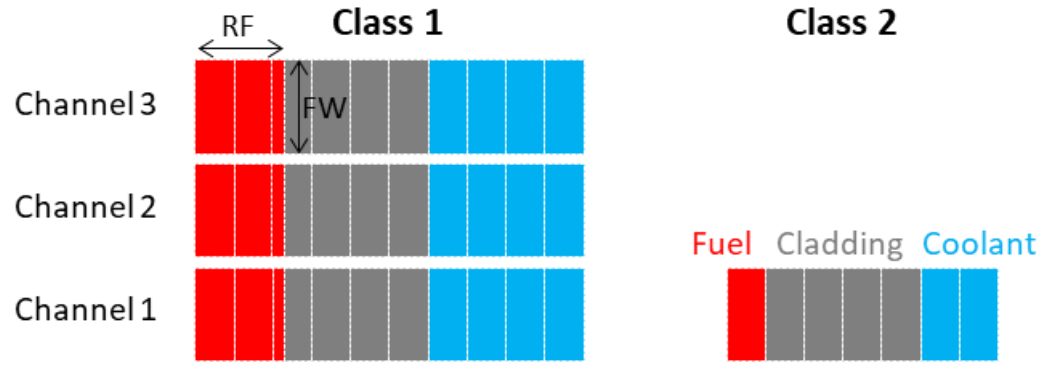

Figure 2.17. Cross-Section of Test Model Using IGEOM = 2 
To simplify the hand calculation process, the input parameters (Table 2.10) are determined with following constrains:

- $\quad$ Same power deposited to each channel:

- Same heat flux at all plate surfaces:

- $\quad$ Averaged PFQ = 1.0:
POWER1 $=3 *$ POWER2

$\mathrm{PFQ} 1 * \mathrm{RF} 1=\mathrm{PFQ} 2 * \mathrm{RF} 2$

$\mathrm{PFQ} 1 * \mathrm{BM} 1+\mathrm{PFQ} 2 * \mathrm{BM} 2=1.0$

Table 2.10. Input Parameters of Test Problem with IGEOM = 2

\begin{tabular}{|l|c|c|}
\hline Model power, $\mathrm{MW}$ & \multicolumn{2}{|c|}{1.0} \\
\hline Total fuel volume, $\mathrm{m}^{3}$ & \multicolumn{2}{|c|}{0.00192} \\
\hline Active fuel length, $\mathrm{m}$ & \multicolumn{2}{|c|}{0.6} \\
\hline Coolant mass flux, $\mathrm{kg} / \mathrm{m}^{2} \mathrm{~s}$ & \multicolumn{2}{|c|}{10000} \\
\hline Inlet coolant temperature, ${ }^{\circ} \mathrm{C}$ & \multicolumn{2}{|c|}{20.0} \\
\hline & Class 1 & Class 2 \\
\hline Number of channels & 3 & 1 \\
\hline Fuel half thickness (RF), mm & 4.66 & 2.00 \\
\hline Clad thickness, $\mathrm{mm}$ & 7.34 & 10 \\
\hline Fuel width (FW), $\mathrm{m}$ & 0.1 & 0.1 \\
\hline Coolant half thickness, $\mathrm{mm}$ & 8.0 & 4.0 \\
\hline Fuel volume fraction (BM) & 0.875 & 0.125 \\
\hline Axial source description for all node (PFQ) & 0.857 & 2.000 \\
\hline
\end{tabular}

Table 2.11. Comparison between Hand and PARET/ANL Calculations with IGEOM = 2

\begin{tabular}{|l|l|c|c|c|c|c|}
\hline \multirow{2}{*}{ Calculated Data } & \multicolumn{2}{c|}{ Class 1 } & \multicolumn{2}{c|}{ Class 2 } & \multirow{2}{*}{ Full Core } \\
\cline { 3 - 7 } & Channel & Class & Channel & Class & \\
\hline \multirow{2}{*}{ Channel power, MW } & Hand & 0.25 & 0.75 & 0.25 & 0.25 & 1.0 \\
\cline { 2 - 7 } & PARET & 0.25 & 0.75 & 0.25 & 0.25 & 1.0 \\
\hline \multirow{2}{*}{ Flowrate, kg/s } & Hand & 16.0 & 48.0 & 8.0 & 8.0 & 56.0 \\
\cline { 2 - 7 } & PARET & 16.0 & 48.0 & 8.0 & 8.0 & 56.0 \\
\hline \multirow{2}{*}{$\begin{array}{l}\text { Coolant temperature rise, } \\
{ }^{\circ} \mathrm{C}\end{array}$} & Hand & 3.737 & & 7.474 & & \\
\hline & PARET & 3.753 & & 7.505 & & \\
\hline \multirow{2}{*}{ Surface heat flux, MW/m } & 2.053 & & \\
\cline { 2 - 7 } & Hand & 2.083 & & 2.083 & & \\
\cline { 2 - 7 } & PARET & 2.083 & & 2.084 & &
\end{tabular}

The obtained results presented in Table 2.11 show a very good agreement between PARET/ANL and hand calculations. Therefore, it is confirmed that the very large differences in all varied input parameters are processed correctly. Note that this test case uses the relative fuel and plate widths (RFW and RPW) equaling to 1.0 as requested by the current code version. Obtained results confirm that the geometry option IGEOM $=2$ works correctly when RFW $=\mathrm{RPW}=1.0$.

\subsection{Capability A4 - Flow Options (Forced or Buoyancy-Driven Flow)}

The flow options used to simulate forced or buoyancy-driven flow can be selected by the input parameter IFLOW as presented in Table 2.12. 
Table 2.12. Flow Options and Test Case

\begin{tabular}{|c|c|c|c|}
\hline Input Setting & \multicolumn{2}{|c|}{ Description } & Test Case \\
\hline IFLOW = 1 & \multicolumn{2}{|c|}{ Forced flow specified by Input Cards 10xxx } & A04_01 \\
\hline IFLOW = 2 & \multicolumn{2}{|c|}{ (Not available in current code version) } & \\
\hline IFLOW = 3 & \multicolumn{2}{|c|}{$\begin{array}{l}\text { Buoyant forced flow (in all channels) with pump coast down } \\
\text { superimposed from Input Cards } 17 x x x \text {. Initial flow rate is computed } \\
\text { from friction pressure drop given in next entry (parameter DELP). }\end{array}$} & A04_02 \\
\hline IFLOW $=4$ & \multicolumn{2}{|c|}{ Same as IFLOW = 3 but initial flow specified by Input Card 10xxx. } & A04_03 \\
\hline \multirow{2}{*}{ IFLOW $=5$} & \multirow{2}{*}{ Buoyancy only (no pump) } & Test case without unfueled part & A04_04 \\
\hline & & Test case with unfueled part & A04_05 \\
\hline
\end{tabular}

The verification of this capability is started with the checking of option IFLOW = 5 using a Mathematica notebook developed to solve the test problem of natural circulation as given by Table 2.13. The Mathematica calculations required starting with an assumed flow rate in the coolant channel. That flow rate was manually adjusted to reach convergence such that the buoyancy pressure drop equaled the frictional pressure drop in the channel. Note that PARET/ANL will use a nominal friction factor of $96 / \mathrm{Re}$ in slab geometry as a starting value, but will correct it when there is heating as described in the User Guide [2]. This friction model is implemented in the Mathematica program for the comparison.

Table 2.13. Input Parameters of Test Problem IFLOW = 5 (test case A04_04)

\begin{tabular}{|l|c|}
\hline Model power, $\mathrm{MW}$ & 0.1 \\
\hline Inlet coolant temperature, ${ }^{\circ} \mathrm{C}$ & 25.0 \\
\hline Inlet pressure, bar & 5.0 \\
\hline Active fuel length, $\mathrm{m}$ & 0.75 \\
\hline Channel thickness, $\mathrm{m}$ & 0.003 \\
\hline Channel width, $\mathrm{m}$ & 0.30 \\
\hline Hydraulic diameter, $\mathrm{m}$ & 0.00594 \\
\hline Inlet K-loss & 0.0 \\
\hline Outlet K-loss & 0.0 \\
\hline Gravity constant, $\mathrm{m} / \mathrm{s}^{2}$ & 9.8 \\
\hline
\end{tabular}

Table 2.14. Results of Test Problem with IFLOW = 5 (test case A04_04)

\begin{tabular}{|l|c|c|}
\hline \multicolumn{1}{|c|}{ Output Parameter } & PARET/ANL & Mathematica \\
\hline Channel mass flux, $\mathrm{kg} / \mathrm{m}^{2} \mathrm{~s}$ & 132.77 & 132.77 \\
\hline Outlet coolant temperature, ${ }^{\circ} \mathrm{C}$ & 75.02 & 75.02 \\
\hline Channel $\Delta \mathrm{P}_{\text {Buoyancy, }} \mathrm{Pa}$ & 66.766 & 66.0 \\
\hline Total $\Delta \mathrm{P}_{\text {Friction, }} \mathrm{Pa}$ & 66.378 & 66.4 \\
\hline
\end{tabular}

Obtained results presented in Table 2.14 show a very good agreement between PARET/ANL run using IFLOW $=5$ and the independent Mathematica notebook. In other words, it is confirmed that the option IFLOW = 5 handles the natural circulation correctly.

The verification of remaining IFLOW options 1,3 , and 4 are performed by comparing their calculation results with the final steady-state natural circulation data obtained with IFLOW $=5$ of a test model. 
To be more general, the test case A04_04 mentioned above is modified to include unfueled parts and the K-loss at the channel inlet and outlet shown in Table 2.15. This forms a new test case A04_05 which is used as the reference case for the checking of other IFLOW options as follows:

- $\quad$ Test case A04_01 is to check IFLOW $=1$. The output natural circulation mass flux calculated by test case A04_05 is used as the forced mass flux at the input cards 10xxx.

- $\quad$ Test case A04_02 is to check IFLOW $=3$. The initial friction pressure drop calculated by test case A04_05 (IFLOW = 5) is used as the parameter DELP on the input card 5xxx. The code searches for the mass flux yielding this pressure drop. The result from the search process initializes the mass flux at time-zero for the transient solution to follow.

- Test case A04-03 is to check IFLOW = 4. It begins with forced downflow stabilized at time zero, continuing through a loss-of-flow event specified by input cards $17 \mathrm{xxx}$ to zero flow at 30 seconds, continuing on to a steady-state upflow solution driven by buoyancy forces.

Table 2.15. Input Parameters of Test Problem of IFLOW = 1, 3, 4, and 5 (cases A04_01, A04_02, A04_03, and A04_05)

\begin{tabular}{|l|c|}
\hline Power, MW & 0.1 \\
\hline Inlet coolant temperature, ${ }^{\circ} \mathrm{C}$ & 25.0 \\
\hline Inlet pressure, bar & 5.0 \\
\hline Unfueled length at top, $\mathrm{m}$ & 0.15 \\
\hline Active fuel length, $\mathrm{m}$ & 0.75 \\
\hline Unfueled length at bottom, $\mathrm{m}$ & 0.15 \\
\hline Channel thickness, $\mathrm{m}$ & 0.003 \\
\hline Channel width, $\mathrm{m}$ & 0.30 \\
\hline Hydraulic diameter, $\mathrm{m}$ & 0.00594 \\
\hline Inlet K-loss & 0.5 \\
\hline Outlet K-loss & 1.0 \\
\hline Gravity constant, $\mathrm{m} / \mathrm{s}^{2}$ & 9.8 \\
\hline
\end{tabular}

Table 2.16. Comparison of Calculation Results

\begin{tabular}{|l|c|c|c|c|}
\hline \multicolumn{1}{|c|}{ Test case } & A04_01 & A04_02 & A04_03 & A04_05 \\
\hline IFLOW option & $\mathbf{1}$ & $\mathbf{3}$ & $\mathbf{4}$ & $\mathbf{5}$ \\
\hline Channel mass flux, $\mathrm{kg} / \mathrm{m}^{2} \mathrm{~S}$ & (input) & 127.89 & 127.89 & 127.89 \\
\hline Outlet coolant temperature, ${ }^{\circ} \mathrm{C}$ & 76.92 & 76.92 & 76.92 & 76.92 \\
\hline Channel $\Delta \mathrm{P}_{\text {friction }} \mathrm{Pa}$ & 103.09 & (input) & 103.09 & 103.09 \\
\hline Total $\Delta \mathrm{P}_{\text {buoyancy, }} \mathrm{Pa}$ & (not edited) & 100.13 & 100.12 & 100.13 \\
\hline
\end{tabular}

Together with comparison between the option IFLOW = 5 and Mathematica notebook (Table 2.14), good agreement between the IFLOW options presented in Table 2.16 confirm that the flow options corresponding to IFLOW $=1,3,4$, and 5 have been implemented correctly. 


\subsection{Capability A5 - Single-Phase Heat Transfer Correlations}

\subsubsection{Description of Code Calculation Method}

As shown in Table 2.17, the heat transfer from fuel plate to single-phase coolant takes place in three flow regimes, i.e., laminar, transition, and turbulent which are separated by the input Reynolds numbers of REL_T and RET_T. The current V\&V will use the default input values of REL_T $=2300$ and RET_T $=3700$ and therefore, the flow regimes to be considered are

- $\quad$ Laminar $(\operatorname{Re}<2300)$ : The calculation is controlled by input IHT options of 0,1 , and 2 .

- Transition ( $2300 \leq \mathrm{Re} \leq 3700)$ : Interpolation is performed between laminar and turbulent regimes.

- Turbulent $(\operatorname{Re}>3700):$ The calculation is controlled by input parameter IONEP.

Table 2.17. Single-Phase Heat Transfer Correlation [2]

\begin{tabular}{|c|c|c|}
\hline $\begin{array}{l}\text { Flow } \\
\text { Regime }\end{array}$ & $\begin{array}{l}\text { Input } \\
\text { Setting }\end{array}$ & Single-Phase Heat Transfer Correlation \\
\hline \multirow{3}{*}{ Laminar } & $\mathrm{IHT}=0$ & $\begin{array}{l}\text { Heat transfer coefficient: } h_{n c}=\frac{1.02 \mathrm{~K} \mathrm{Re} e^{0.45} \mathrm{Pr}^{1 / 3}}{D_{\mathrm{e}}^{0.6} \mathrm{Lh}^{0.4}} \times\left(\frac{\mu}{\mu_{w}}\right)^{0.14} \times \delta\left(T_{w^{-}} T_{b}\right)^{n} \\
\text { where } \delta \text { and } n \text { are specified by input HTTCON and HTTEXP }\end{array}$ \\
\hline & $\mathrm{IHT}=1$ & $\begin{array}{l}\text { Without entrance effect: } h_{n c}=\mathrm{Nu} * \mathrm{~K} / \mathrm{D}_{\mathrm{e}} \\
\text { where } \mathrm{Nu} \text { is specified by input HTTCON }\end{array}$ \\
\hline & $\mathrm{IHT}=2$ & $\begin{array}{l}\text { With entrance effect: } h_{n c}=(\mathrm{Nu}+X)^{*} \mathrm{~K} / \mathrm{D}_{\mathrm{e}} \\
\text { where } \mathrm{Nu} \text { is specified by input HTTCON, and } X \text { is obtained using a lookup table of } \\
\text { Graetz number: } \mathrm{Gz}=\frac{D_{e} \operatorname{RePr}}{z} \text {, with } \mathrm{z} \text { is the distance from inlet }\end{array}$ \\
\hline Transition & $\begin{array}{l}\text { IHT \& } \\
\text { IONEP }\end{array}$ & $\begin{array}{l}\text { Heat transfer coefficient: } h_{\text {tran }}=h_{n c} *(1-x)+h_{t u r b} * x \\
\text { where } h_{n c} \text { and } h_{\text {turb }} \text { are obtained by applying laminar and turbulent correlations to } \\
\text { the Re under consideration and } x=\left(R e-R E L_{-} T\right) /\left(R E T \_T-R E L_{-} T\right)\end{array}$ \\
\hline \multirow{4}{*}{ Turbulent } & IONEP $=0$ & Dittus-Boelter: $\mathrm{Nu}=0.023 \mathrm{Re}^{0.8} \mathrm{Pr}^{0.4}$ \\
\hline & IONEP $=1$ & Sieder-Tate $: \mathrm{Nu}=0.027 \operatorname{Re}^{0.8} \operatorname{Pr}^{1 / 3}\left(\frac{\mu_{b}}{\mu_{w}}\right)^{0.14}$ \\
\hline & IONEP $=2$ & $\begin{array}{l}\text { Petukhov-Popov: } h_{\mathrm{FC}}=\frac{\frac{k_{b} f_{D}}{\operatorname{De} 8} \operatorname{RePr}\left(\frac{\mu_{b}}{\mu_{w}}\right)^{0.11}}{\left(1+3.4 f_{D}\right)+\left(11.7+\frac{1.8}{\operatorname{Pr}^{1 / 3}}\right)\left(\frac{f_{D}}{8}\right)^{\frac{1}{2}}\left(\operatorname{Pr}^{2 / 3}-1.0\right)} \\
\text { where } f_{D}=\frac{1.0875-0.1125\left(\frac{b}{s}\right)}{(1.82 \log \operatorname{Re}-1.64)^{2}} ; b \text { and } s \text { are the thickness and span or the larger side of } \\
\text { the rectangular cross section of the channel. }\end{array}$ \\
\hline & IONEP $=3$ & $\begin{array}{l}\text { Colburn: } \mathrm{Nu}=0.023 \mathrm{Re}^{0.8} \mathrm{Pr}^{0.3} \\
\text { with fluid properties calculated at film temperature } T_{\text {film }}=\left(T_{\text {clad }}+T_{b}\right) / 2\end{array}$ \\
\hline
\end{tabular}




\begin{tabular}{|l|l|l|}
\hline & IONEP=4 & Russian: $\mathrm{Nu}=0.021 \operatorname{Re}^{0.8} \operatorname{Pr}^{0.43}\left(\frac{\mu_{b}}{\mu_{w}}\right)^{0.25}$ \\
\cline { 2 - 4 } & IONEP=6 & Dittus-Boelter modified by ANL: $\mathrm{Nu}=0.023 \operatorname{Re}^{0.8} \operatorname{Pr}^{0.4}\left(\frac{\mu_{b}}{\mu_{w}}\right)^{0.11}$ \\
\hline
\end{tabular}

Note:

- Option IONEP = 5 corresponding to China Inst. of Atomic Energy MNSR correlation is currently not used and therefore, it is not considered under this $V \& V$.

- Using the positive values of IONEP as shown in this table will activate the Rosenthal \& Miller correlation. The code, however, only uses this correlation in the case of extremely rapid power increase and very low flow rate which is not considered under the current $V \& V$.

\subsubsection{Verification Approach}

A single-channel base model using slab geometry and flat power distribution with four axial nodes is set up for the comparison between PARET/ANL and hand calculations (Table 2.18). Then, the test cases are created by specifying the IHT and IONEP, as well as by adjusting the mass flux and total reactor power to achieve the single-phase flow conditions corresponding to laminar, transition, and turbulent regimes (Table 2.19).

Table 2.18. Base Model Specifications

\begin{tabular}{|l|c|}
\hline Total fuel volume, $\mathrm{m}^{3}$ & 0.00144 \\
\hline Active fuel length, $\mathrm{m}$ & 0.6 \\
\hline Inlet coolant temperature, ${ }^{\circ} \mathrm{C}$ & 20.0 \\
\hline Fuel thickness, $\mathrm{mm}$ & 4.0 \\
\hline Plate thickness, $\mathrm{mm}$ & 12.0 \\
\hline Channel fuel width, $\mathrm{m}$ & 0.1 \\
\hline Axial source description for all node (PFQ) & 1.000 \\
\hline
\end{tabular}

Table 2.19. Input Setting for Test Cases

\begin{tabular}{|c|c|c|c|c|c|c|}
\hline \multirow{2}{*}{$\begin{array}{l}\text { Flow } \\
\text { Regime }\end{array}$} & \multirow{2}{*}{$\begin{array}{l}\text { Input } \\
\text { Setting }\end{array}$} & \multirow{2}{*}{$\begin{array}{c}\text { Mass Flux, } \\
\mathrm{kg} / \mathrm{m}^{2} \mathrm{~s}\end{array}$} & \multirow{2}{*}{$\begin{array}{c}\text { Total Power, } \\
\text { MW }\end{array}$} & \multicolumn{2}{|c|}{ Input Constant } & \multirow{2}{*}{$\begin{array}{l}\text { Test } \\
\text { Case }\end{array}$} \\
\hline & & & & HTTCON & HTTEXP & \\
\hline \multirow{3}{*}{ Laminar } & $\mathrm{IHT}=0$ & 100 & 0.02 & 1.4 & 0.33 & A05_01 \\
\hline & $\mathrm{IHT}=1$ & 100 & 0.02 & 30 & - & A05_02 \\
\hline & $\mathrm{IHT}=2$ & 100 & 0.02 & 30 & - & A05_03 \\
\hline Transition & $\begin{array}{c}\mathrm{IHT}=0 \\
\mathrm{IONPE}=0\end{array}$ & 180 & 0.02 & 1.4 & 0.33 & A05_04 \\
\hline \multirow{6}{*}{ Turbulent } & IONEP $=0$ & 2000 & 0.2 & - & - & A05_05 \\
\hline & IONEP $=1$ & 2000 & 0.2 & - & - & A05_06 \\
\hline & IONEP $=2$ & 2000 & 0.2 & - & - & A05_07 \\
\hline & IONEP $=3$ & 2000 & 0.2 & - & - & A05_08 \\
\hline & IONEP $=4$ & 2000 & 0.2 & - & - & A05_09 \\
\hline & IONEP $=6$ & 2000 & 0.2 & - & - & A05_10 \\
\hline
\end{tabular}

Using a Microsoft Excel spreadsheet, the hand calculation of each of these test cases implements the corresponding heat transfer correlation as follows:

- If the Dittus-Boelter correlation is used (turbulent regime and IONEP = 1),

$\circ$ Calculate bulk temperature $T_{b}$ and surface heat flux 
- Use NIST table add-on for Excel [7] to determine coolant properties at bulk temperature $T_{b}$ and input pressure

- Calculate the $\mathrm{Re}, \mathrm{Pr}, \mathrm{Nu}$, and $h$

- If a laminar or turbulent correlation other than the Dittus-Boelter is used, the calculation involving the clad surface temperature is performed iteratively:

- Calculate bulk temperature $T_{b}$ and surface heat flux. These values are constant during the iteration.

- Assume an axial profile of clad surface temperatures, $T_{\text {clad } \_} A$

- Calculate reference coolant temperature $T_{\text {film }}$ from $T_{b}$ and $T_{\text {clad_A }}$

- Determine coolant properties at $T_{\text {film }}$

- Calculate the $\mathrm{Re}, \mathrm{Pr}, \mathrm{Nu}$, and $h$

- Calculate new $T_{\text {clad }}$ using $h$ and PARET's output surface heat flux

- Using Excel solver, adjust $T_{\text {clad_A }}$ until $\sum\left(T_{\text {clad }}-T_{\text {clad_A }}\right)^{2}<1 \mathrm{E}-10$

- In the case of the transition flow regime (2300 $\leq \mathrm{Re} \leq 3700)$, as shown in Table 2.17, the heat transfer coefficients $h_{n c}$ and $h_{\text {turb }}$ must be calculated simultaneously using a single wall temperature that is the actual wall temperature corresponding to the heat transfer coefficient in the transition flow regime, $h_{\text {tran }}$. This is done on spreadsheet by performing the following calculation steps iteratively for a local axial node:

- Calculate bulk temperature $T_{b}$ and surface heat flux. These values are constant during the iteration.

- Assume an axial profile of clad surface temperatures $\left(T_{\text {clad_A } A}\right)$

- Determine coolant properties at $T_{b}$ and $T_{\text {clad_A }}$

- Calculate Re, $\mathrm{Pr}, \mathrm{Nu}$

- Calculate $h_{n c}$ by applying the laminar correlation to the obtained Re

- Calculate $h_{\text {turb }}$ by applying the turbulent correlation to the obtained $\operatorname{Re}$

- Calculate $x$ and $h_{\text {tran }}$

- Calculate new $T_{\text {clad }}$ using $h_{\text {tran }}$ and surface heat flux

○ Using Excel solver, adjust $T_{\text {clad_A }}$ until $\sum\left(T_{\text {clad }}-T_{\text {clad_A }}\right)^{2}<1 \mathrm{E}-10$

\subsubsection{Calculation Results}

The comparison between PARET/ANL and hand calculations for all flow regimes is presented in Table 2.20. Good agreements are obtained for all test cases. Those with the largest differences are A5_02, A5_03, and A5_04. The relative differences in all cases comes from the differences in water properties calculated by the NIST Table add-on for Excel and by the PARET/ANL code.

As shown in Table 2.17, the heat transfer coefficient in cases A5_02 and A5_03 is calculated directly from the input Nusselt number (input parameter HTTCON) and coolant thermal conductivity. Therefore, the difference in thermal conductivity will show up in the heat transfer coefficient. The difference in coolant properties has the strongest impact on the transition flow regime (test case A5_04) because the Re is used for the interpolation between laminar and turbulent heat transfer correlation.

Overall, the differences in heat transfer coefficients obtained by PARET/ANL and hand calculations using water properties from NIST Tables are accepted for the application. 
Table 2.20. Comparison of PARET/ANL and Hand Calculations

\begin{tabular}{|c|c|c|c|c|c|c|c|c|c|c|}
\hline \multirow[b]{2}{*}{$\begin{array}{c}\text { Flow } \\
\text { Regime }\end{array}$} & \multirow[b]{2}{*}{$\begin{array}{l}\text { Test } \\
\text { Case }\end{array}$} & \multicolumn{2}{|c|}{ Setting } & \multirow[b]{2}{*}{$\begin{array}{c}\text { Axial } \\
\text { Location }\end{array}$} & \multicolumn{3}{|c|}{ Reynolds Number* } & \multicolumn{3}{|c|}{ H.T. Coefficient, $\mathrm{W} / \mathrm{m}^{2} \mathrm{~s}$} \\
\hline & & IHT & IONEP & & PARET & Hand & $\begin{array}{c}\text { Diff., } \\
\%\end{array}$ & PARET & Hand & $\begin{array}{c}\text { Diff., } \\
\%\end{array}$ \\
\hline \multirow{6}{*}{ Laminar } & \multirow{2}{*}{ A05_01 } & \multirow{2}{*}{0} & \multirow[b]{2}{*}{ - } & Inlet & 1575.5 & 1596.7 & 1.34 & 2409.9 & 2419.9 & 0.42 \\
\hline & & & & Outlet & 1987.0 & 2006.2 & 0.97 & 2475.1 & 2484.4 & 0.38 \\
\hline & \multirow{2}{*}{ A05_02 } & \multirow{2}{*}{1} & \multirow{2}{*}{ - } & Inlet & 1575.5 & 1596.7 & 1.34 & 1138.5 & 1121.3 & 1.51 \\
\hline & & & & Outlet & 1987.0 & 2006.2 & 0.97 & 1165.8 & 1152.0 & 1.18 \\
\hline & \multirow{2}{*}{ A05_03 } & \multirow{2}{*}{2} & \multirow{2}{*}{ - } & Inlet & 1575.5 & 1596.7 & 1.34 & 1473.0 & 1454.0 & 1.29 \\
\hline & & & & Outlet & 1987.0 & 2006.2 & 0.97 & 1414.2 & 1400.0 & 1.01 \\
\hline \multirow{2}{*}{ Transition } & \multirow{2}{*}{ A05_04 } & \multirow{2}{*}{0} & \multirow{2}{*}{0} & Inlet & 2835.9 & 2874.0 & 1.34 & 2369.9 & 2335.0 & 1.47 \\
\hline & & & & Outlet & 3233.6 & 3275.7 & 1.30 & 1936.9 & 1886.6 & 2.60 \\
\hline \multirow{12}{*}{ Turbulent } & \multirow{2}{*}{ A05_05 } & \multirow{2}{*}{-} & \multirow{2}{*}{0} & Inlet & 31510.0 & 31933.6 & 1.34 & 7529.1 & 7516.7 & 0.16 \\
\hline & & & & Outlet & 35464.8 & 35940.2 & 1.34 & 7950.7 & 7945.7 & 0.06 \\
\hline & \multirow{2}{*}{ A05_06 } & \multirow{2}{*}{-} & \multirow{2}{*}{1} & Inlet & 31510.0 & 31933.6 & 1.34 & 9016.3 & 8992.1 & 0.27 \\
\hline & & & & Outlet & 35464.8 & 35940.2 & 1.34 & 9475.3 & 9463.5 & 0.12 \\
\hline & \multirow{2}{*}{ A05_07 } & \multirow{2}{*}{-} & \multirow{2}{*}{2} & Inlet & 31510.0 & 31933.6 & 1.34 & 9823.2 & 9852.9 & 0.30 \\
\hline & & & & Outlet & 35464.8 & 35940.2 & 1.34 & 10269.8 & 10315.2 & 0.44 \\
\hline & \multirow{2}{*}{ A05_08 } & \multirow{2}{*}{ - } & \multirow{2}{*}{3} & Inlet & 59931.6 & 59754.4 & 0.30 & 8964.6 & 8892.5 & 0.80 \\
\hline & & & & Outlet & 63884.3 & 63650.4 & 0.37 & 9297.3 & 9220.3 & 0.83 \\
\hline & & & 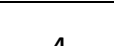 & Inlet & 31510.0 & 31933.6 & 1.34 & 9438.8 & 9408.5 & 0.32 \\
\hline & AUS_U9 & - & 4 & Outlet & 35464.8 & 35940.2 & 1.34 & 9725.8 & 9712.1 & 0.14 \\
\hline & & & & Inlet & 31510.0 & 31933.6 & 1.34 & 8502.1 & 8489.5 & 0.15 \\
\hline & AUS_ & - & 6 & Outlet & 35464.8 & 35940.2 & 1.34 & 8884.1 & 8884.9 & 0.01 \\
\hline
\end{tabular}

* The Reynolds numbers are calculated using bulk temperature except for the test case A5_08 where the film temperature is used.

\subsection{Capability A6 - Factor Used for Fin or Bundle Effect}

Through the input parameter FINF, the PARET/ANL code allows the user to specify a scaling factor to account for the effect of the fuel bundles or the fins (on the cladding surface) on the turbulent heat transfer. This scaling factor is applied to the heat transfer coefficient which in turn is used to calculate the cladding temperature during the iterative calculation scheme.

The verification of this scaling process is performed through the comparison between the code and hand calculations. The Excel spreadsheet used for the hand calculation of heat transfer presented in Section 2.5 is modified to include the input scale factor to the calculation of heat transfer coefficient. Two test cases used in the Section 2.5, A05_05 (Dittus-Boelter correlation) and A05_06 (Sieder-Tate correlation), are also modified to be A06_01 and A06_02, respectively, by changing the input FINF from 1.0 to 2.5 for the comparison purpose. The test cases and obtained calculation results are presented in Table 2.21 . 
Table 2.21. Comparison of PARET/ANL and Hand Calculations

\begin{tabular}{|c|c|c|c|c|c|c|c|}
\hline \multirow{2}{*}{ Test Case } & \multicolumn{2}{|c|}{ Input Setting } & \multirow{2}{*}{ Description } & \multirow{2}{*}{$\begin{array}{c}\text { Axial } \\
\text { Location }\end{array}$} & \multicolumn{2}{|c|}{ H.T. Coefficient, $\mathrm{W} / \mathrm{m}^{2} \mathrm{~s}$} & \multirow{2}{*}{ Diff., \% } \\
\hline & IONEP & FINF & & & PARET & Hand & \\
\hline \multirow{2}{*}{ A05_05 } & \multirow{2}{*}{0} & \multirow{2}{*}{1.0} & \multirow{2}{*}{$\begin{array}{l}\text { Dittus-Boelter correlation } \\
\text { without scaling }\end{array}$} & Inlet & 7529.1 & 7516.7 & 0.16 \\
\hline & & & & Outlet & 7950.7 & 7945.7 & 0.06 \\
\hline \multirow{2}{*}{ A06_01 } & \multirow{2}{*}{0} & \multirow{2}{*}{2.5} & \multirow{2}{*}{$\begin{array}{l}\text { Dittus-Boelter correlation } \\
\text { with scaling }\end{array}$} & Inlet & 18822.7 & 18791.8 & 0.16 \\
\hline & & & & Outlet & 19876.6 & 19864.2 & 0.06 \\
\hline \multirow{2}{*}{ A05_06 } & \multirow{2}{*}{1} & \multirow{2}{*}{1.0} & \multirow{2}{*}{$\begin{array}{l}\text { Sieder-Tate correlation } \\
\text { without scaling }\end{array}$} & Inlet & 9016.3 & 8992.1 & 0.27 \\
\hline & & & & Outlet & 9475.3 & 9463.5 & 0.12 \\
\hline \multirow{2}{*}{ A06_02 } & \multirow[b]{2}{*}{$\perp$} & \multirow{2}{*}{2.5} & \multirow{2}{*}{$\begin{array}{l}\text { Sieder-Tate correlation } \\
\text { with scaling }\end{array}$} & Inlet & 21010.7 & 20916.2 & 0.45 \\
\hline & & & & Outlet & 22208.4 & 22127.8 & 0.36 \\
\hline
\end{tabular}

Table 2.21 shows that the PARET/ANL results agree well with hand calculations for all test cases. It should be noted that the calculated heat transfer coefficient is scaled by a factor of 2.5 in the case of Dittus-Boelter correlation and by a factor of 2.33 in the case of Sieder-Tate correlation. The reason is that the Dittus-Boelter correlation does not use the cladding temperature to calculate the heat transfer coefficient, while the Sieder-Tate correlation does. In fact, the heat transfer calculation using Sieder-Tate or a correlation other than Dittus-Boelter requires iteration between the heat transfer coefficient and cladding temperature. As mentioned in Section 2.5, the Excel spreadsheet was designed to use its solver capability to perform this iteration. Overall, the very good agreement between code and hand calculations confirms that the implementation of the scaling factor FINF in the code is correct.

\subsection{Capability A7 - Subcooled Nucleate Boiling Heat Transfer}

PARET/ANL includes two-phase heat transfer correlation options to model nucleate boiling (input parameter ITWOP), transient two-phase scheme (IMODE), and departure from nucleate boiling and flow instability (ICHF). Due to the limitation in the V\&V tools, however, the current work only considers the subcooled nucleate boiling regime controlled by the input parameter ITWOP as presented in Table 2.22 . 
Table 2.22. Subcooled Boiling Heat Transfer Correlation [2]

\begin{tabular}{|c|c|c|c|}
\hline $\begin{array}{c}\text { Flow } \\
\text { Regime }\end{array}$ & $\begin{array}{c}\text { Input } \\
\text { Setting }\end{array}$ & Heat Transfer Correlation & $\begin{array}{l}\text { Test } \\
\text { Case }\end{array}$ \\
\hline \multirow[t]{2}{*}{$\begin{array}{l}\text { Subcooled } \\
\text { Nucleate } \\
\text { Boiling }\end{array}$} & ITWOP=0 & $\begin{array}{l}\text { Heat flux boundary condition: }\left(q_{\mathrm{NB}}^{\prime \prime}\right)^{m+1}=\left(q_{\mathrm{NB}}^{\prime \prime}\right)^{m}\left[1+\frac{4\left(u_{s}^{m+1}-u_{s}^{\prime m}\right)}{u_{s}^{\prime m}-u_{\mathrm{sat}}}\right] \\
\text { where } m \text { refers to the } \mathrm{m}^{\text {th }} \text { node. } \\
\text { This boundary condition is based on the Jens-Lottes correlation: } \\
\qquad u_{s}^{\prime}=u_{\text {sat }}+60 \exp \left(-\frac{p}{900}\right)\left(\frac{q^{\prime \prime}}{10^{6}}\right)^{\frac{1}{4}}\end{array}$ & A02_01 \\
\hline & ITWOP=1 & $\begin{array}{l}\text { McAdams correlation: } q^{\prime \prime}=0.074\left(T_{w}-T_{\text {sat }}\right)^{3.86} \\
\text { The constant } 0.074 \text { varies with the extent of degassing of the water. It was } \\
\text { found to be } 0.074 \text { at } 0.06 \mathrm{ml} \text {. of air at standard conditions per liter of water. }\end{array}$ & A07_01 \\
\hline
\end{tabular}

The verification of these subcooled heat transfer correlations is based on code-to-code comparisons between PARET/ANL and RELAP5. It should be noted that RELAP5 does not use the Jens-Lottes or the McAdams correlations. Instead, the subcooled nucleate boiling is handled by the Chen correlation [8]. The difference in heat transfer correlations used by the codes would affect the validity of the current V\&V. However, the code-to-code comparison still provides strong evidence on the performance of each code.

As mentioned in section 2.2 , the test case A02_01 was previously created for the code-to-code comparison, and it uses ITWOP $=0$. This case is modified using ITWOP $=1$ to form a new test case A07_01. Results from these two test cases are presented in Figure 2.18 and Table 2.23. As the heat transfer mode is changed from single-phase liquid to subcooled nucleate boiling at $\sim 1.03 \mathrm{sec}$, the application of different heat transfer correlations lead to differences in calculated temperatures. The results obtained by PARET/ANL bound those by RELAP5 and the using of ITWOP=1 is more conservative. Given the complexity of the nucleate boiling heat transfer, it can be conclude that the codes' calculations agree to each other. Therefore, it is concluded that the subcooled boiling heat transfer regime is correctly modeled in PARET/ANL and is verified through comparison to the RELAP5 code. 

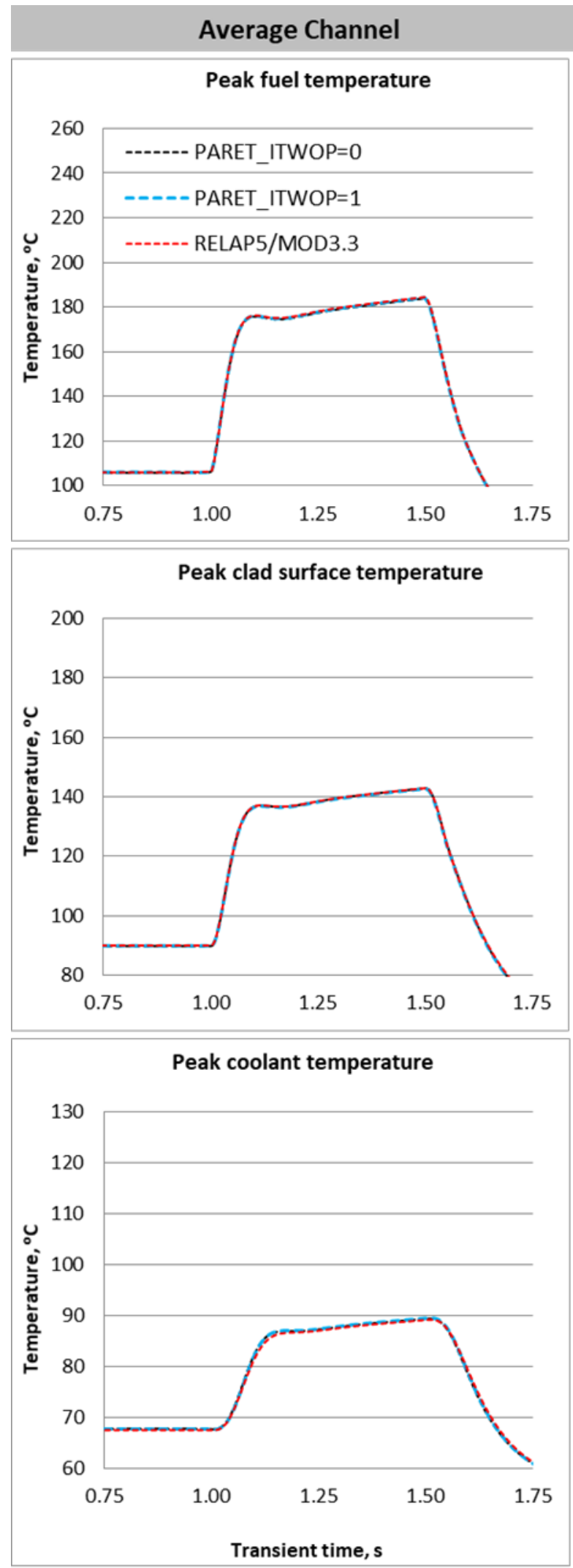

Hot Channel

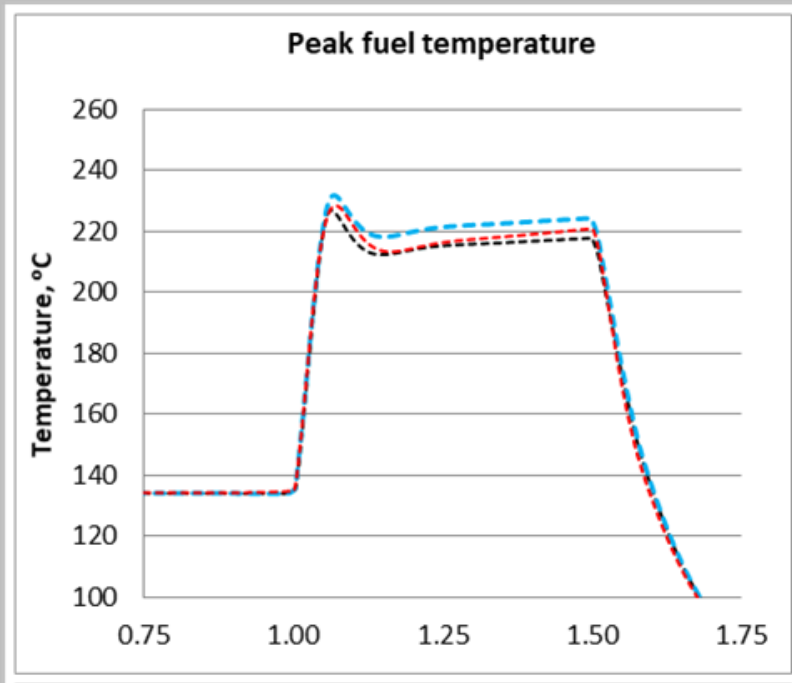

Peak clad surface temperature

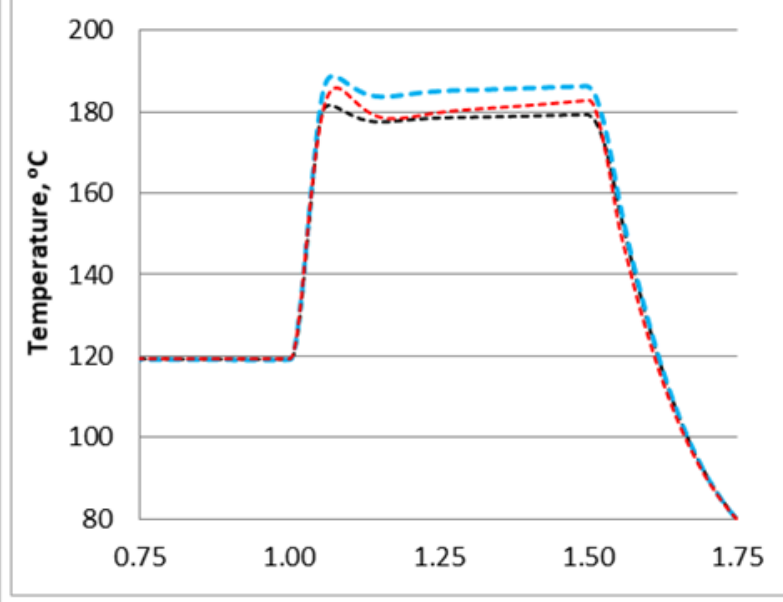

Peak coolant temperature

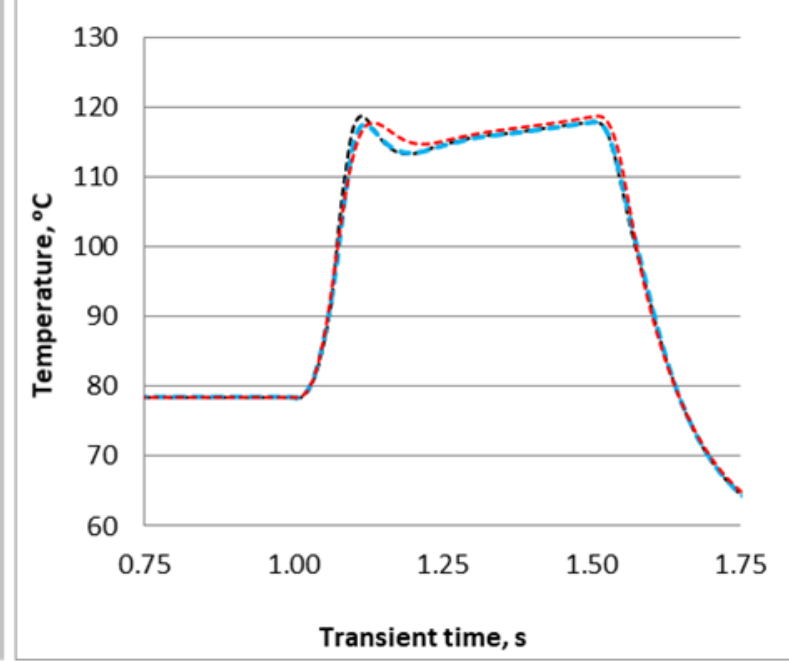

Figure 2.18. Comparison of Transient Data 
Table 2.23. Comparison of Transient Peak Temperatures

\begin{tabular}{|l|l|c|c|c|}
\hline \multirow{2}{*}{ Component } & \multirow{2}{*}{ Channel } & \multicolumn{2}{|c|}{ PARET/ANL } & \multirow{2}{*}{ RELAP5/MOD3.3 } \\
\cline { 3 - 4 } & & ITWOP=0 & ITWOP=1 & \\
\hline \multirow{2}{*}{ Fuel meat } & Average & 184.0 & 184.0 & 184.2 \\
\cline { 2 - 4 } & Hot & 226.5 & 231.8 & 228.1 \\
\hline \multirow{2}{*}{ Cladding } & Average & 142.8 & 142.8 & 142.9 \\
\cline { 2 - 4 } & Hot & 181.5 & 188.9 & 186.1 \\
\hline \multirow{2}{*}{ Coolant } & Average & 89.4 & 89.4 & 89.1 \\
\cline { 2 - 4 } & Hot & 118.8 & 118.0 & 118.9 \\
\hline
\end{tabular}

\subsection{Capability A8 - Friction Factor Correlations}

For an unheated channel, the friction factor is calculated for all Reynolds number and geometry options as shown in Table 2.24. Verification of these correlations is performed by comparing results from PARET/ANL and hand calculations. For this comparison, test case A05_05 described in Section 2.5 is modified as follows:

- Set power to 1.0E-3 W to form a new test case A08_01;

- Set power to 1.0E-3 W and change IGEOM to 1 to form new test cases A08_02;

- Set power to $1.0 \mathrm{E}-3 \mathrm{~W}$ and increase mass flux to 2000 and $3000 \mathrm{~kg} / \mathrm{m}^{2} \mathrm{~s}$ to form new test cases A08_03 and A8_04, respectively.

Table 2.24. Friction Factor Correlation for Unheated Channel [2]

\begin{tabular}{|c|l|c|c|}
\hline $\mathbf{R e}$ & \multicolumn{1}{|c|}{ Geometry Options } & Friction Correlations & Test Case \\
\hline \multirow{2}{*}{$\operatorname{Re} \leq 2000$} & Rectangular channel (IGEOM = 0 or 2) & $f=96 / \operatorname{Re}$ & A08_01 \\
\cline { 2 - 4 } & Cylindrical channel (IGEOM = 1) & $f=64 / \operatorname{Re}$ & A08_02 \\
\hline $2000<\operatorname{Re} \leq 100,000$ & All geometry options & $f=0.210816 * \mathrm{Re}^{-0.213727}$ & A08_03 \\
\hline $\operatorname{Re}>100,000$ & All geometry options & $f=0.11437 * \mathrm{Re}^{-0.160608}$ & A08_04 \\
\hline
\end{tabular}

As the verification for the calculation of Re has previously been performed under Section 2.5 , the current hand calculation is simplified by using the Re calculated by the code. The comparison between PARET/ANL and hand calculations for all flow regimes presented in Table 2.25 confirms that the friction factor correlations for unheated channel are implemented correctly. 
Table 2.25. Comparison of PARET/ANL and Hand Calculations

\begin{tabular}{|c|c|c|c|c|}
\hline \multirow{2}{*}{ Test Case } & \multirow{2}{*}{$\begin{array}{c}\text { Re (Calculated by } \\
\text { PARET) }\end{array}$} & Friction Factor \\
\cline { 3 - 5 } & 1576 & 0.0609 & Hand & Diff., \% \\
\hline A08_01 & 1260 & 0.0508 & 0.0609 & 0.0 \\
\hline A08_02 & 84027 & 0.0187 & 0.0508 & 0.0 \\
\hline A08_03 & 126040 & 0.0173 & 0.0173 & 0.0 \\
\hline A08_04 & \multicolumn{3}{|c|}{0.0} \\
\hline
\end{tabular}

Given a heat source in fuel plates, the base fiction factor calculated above is corrected using a multiplication factor called "the heated wall effect" defined by

$$
f_{H W}=1.0+\frac{p_{\text {heat }}}{p_{\text {wet }}} *\left[\left(\frac{\mu_{w}}{\mu_{b}}\right)^{0.54}-1.0\right]
$$

where $f_{H W}$ is the correction factor for the heated wall; $p_{\text {heat }}$ and $p_{\text {wet }}$ are heated and wetted perimeters ( $p_{\text {heat }} / p_{\text {wet }}$ is set to 1.0 in the code); $\mu_{w}$ is coolant viscosity at temperature of the wall; and $\mu_{b}$ is the bulk coolant viscosity.

The V\&V of the friction factor involving the heated wall effect is included in the Section 2.4 in which very good agreement is obtained between the PARET/ANL and independent Mathematica calculations of test case. The results presented in Table 2.14do not validate each friction factor at each axial node directly, but they do validate the total pressure drop, mass flow rate, and coolant exit temperature - all of which are extremely dependent on the friction factors involved. Agreement would be impossible if the friction factors were incorrect. The friction factor comparison between PARET/ANL and Mathematica for test case A04-04 in the laminar flow range is presented in Figure 2.19 .

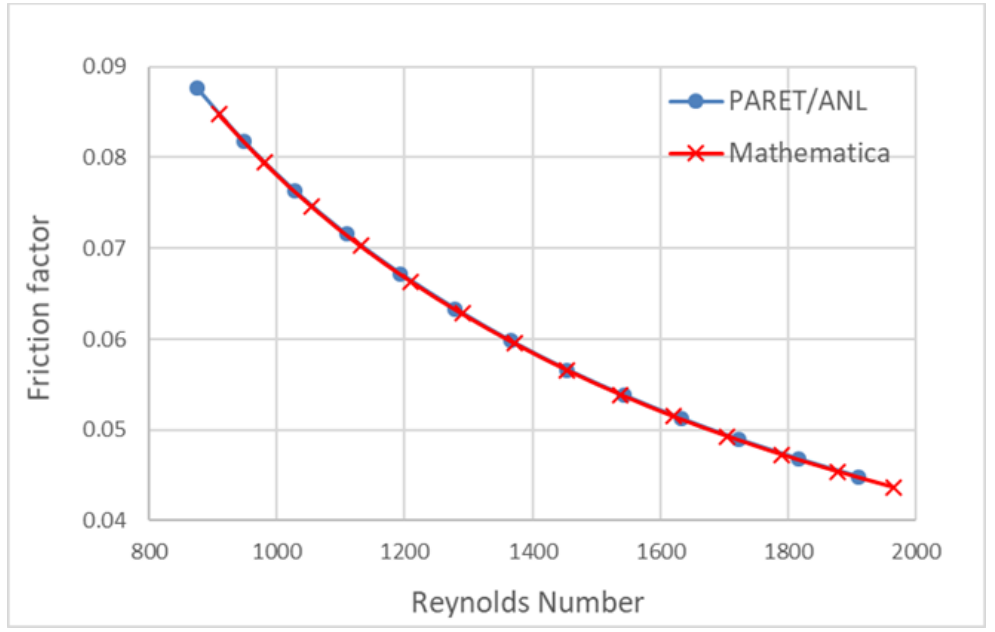

Figure 2.19. Comparison of Friction Factor between PARET/ANL and Mathematica

Overall, the comparisons between PARET/ANL calculations with auxiliary calculations for unheated channel cases and with the Mathematica calculation of test case A04_04 for a heated channel confirm that the friction factor correlations are implemented correctly. 


\subsection{Capability A9 - Steady-State Initialization}

PARET/ANL allows the user to control how steady-state initialization is performed through options on Input Card 22000. This capability is verified by comparing between the initialization calculation and a null-transient run of a test case. In Section 2.5, the steady-state of test case A05_01 was constructed using the steady-state initialization option. This test case is modified by setting the initializing time to $0.0 \mathrm{sec}$ and running with constant power and mass flux for 10 seconds and for 300 seconds (null transient) to form a new test case A09_01. One can observe that the 10 second null transient is not fully converged to the steady-state result in column 3 . The 300 second null transient agrees extremely closely with the steady-state result in column 3. Calculation results presented in Table 2.26 confirm that the steady-state initialization capability is implemented correctly in PARET/ANL.

Table 2.26. Comparison of PARET/ANL and Hand Calculations

\begin{tabular}{|l|l|c|c|c|c|}
\hline \multirow{2}{*}{ Parameter } & \multirow{2}{*}{$\begin{array}{c}\text { Axial } \\
\text { Location }\end{array}$} & $\begin{array}{c}\text { With Steady-State } \\
\text { Initialization } \\
\text { (A05_01) }\end{array}$ & \multicolumn{2}{|c|}{$\begin{array}{c}\text { Null Transient } \\
\text { (A09_01) }\end{array}$} & \multirow{2}{*}{$\begin{array}{c}\text { [A] vs. [B] } \\
\text { Diff., \% }\end{array}$} \\
\cline { 3 - 5 } & & $\mathbf{0 . 0 \text { s [A] }}$ & $\mathbf{1 0 . 0 ~ s}$ & $\mathbf{3 0 0}$ s [B] & \\
\hline \multirow{2}{*}{ Enthalpy, $\mathrm{kJ} / \mathrm{kg}$} & Inlet & 83.66 & 83.66 & 83.66 & 0.000 \\
\cline { 2 - 6 } & Outlet & 125.32 & 126.16 & 125.33 & 0.003 \\
\hline \multirow{2}{*}{ Coolant temperature, ${ }^{\circ} \mathrm{C}$} & Inlet & 19.98 & 19.98 & 19.98 & 0.000 \\
\cline { 2 - 6 } & Outlet & 29.98 & 30.18 & 29.98 & 0.003 \\
\hline \multirow{2}{*}{ Clad surface temp., ${ }^{\circ} \mathrm{C}$} & Inlet & 43.03 & 42.43 & 43.03 & 0.000 \\
\cline { 2 - 6 } & Outlet & 52.42 & 64.73 & 52.43 & 0.005 \\
\hline \multirow{2}{*}{ Fuel centerline temp., ${ }^{\circ} \mathrm{C}$} & Inlet & 48.59 & 47.87 & 48.59 & 0.000 \\
\cline { 2 - 6 } & Outlet & 57.98 & 73.10 & 57.98 & 0.003 \\
\hline \multirow{2}{*}{ Heat transfer coef., $\mathrm{W} / \mathrm{m}^{2} \mathrm{~K} \mathrm{~K}$} & Inlet & 2409.86 & 2385.90 & 2409.86 & 0.000 \\
\cline { 2 - 5 } & Outlet & 2475.76 & 2914.73 & 2475.86 & 0.004 \\
\hline
\end{tabular}




\section{Verification of Transient Capabilities}

\subsection{Capability B1 - Point Kinetics Model}

Several verification exercises have been carried out for the point kinetics algorithm used in PARET/ANL. In the following paragraphs, PARET/ANL calculations using Version 7.6 are compared with semi-analytic solutions in the case of step reactivity changes or with a published benchmarking calculation for a positive ramp reactivity insertion. For a negative ramp reactivity insertion and a case with feedback, the PARET/ANL results are compared with the solution generated using an independent point kinetics solution method. These cases demonstrate that the PARET/ANL point kinetics solution algorithm generates highly accurate solutions for the reactor power and for the delayed neutron concentrations as functions of time.

The verification of this capability considers both step and ramp reactivity changes using the test cases presented in Table 3.1. Note that the initial powers in PARET/ANL models are set to small values (1.0E-90 MW for cases B01_01 to B01_20 and 1.0E-30 MW for cases B01_21 to B01_28) to avoid any thermal-hydraulic feedback reactivity effects. Hence, the corresponding output powers were multiplied by $1.0 \mathrm{E}+90$ or $1.0 \mathrm{E}+30$ to compare with the reference data.

Table 3.1. Test Cases Used for the Verification of the Point Kinetics Model

\begin{tabular}{|c|c|c|c|}
\hline Type & $\begin{array}{l}\text { Reactivity } \\
\text { Insertion }\end{array}$ & Time Step, s & Test Case \\
\hline \multirow{20}{*}{$\begin{array}{l}\text { Step } \\
\text { insertion }\end{array}$} & \multirow{4}{*}{$1.0 \$$} & 0.0001 & B01_01 \\
\hline & & 0.001 & B01_02 \\
\hline & & 0.01 & B01_03 \\
\hline & & 0.1 & B01_04 \\
\hline & \multirow{4}{*}{$0.5 \$$} & 0.0001 & B01_05 \\
\hline & & 0.001 & B01_06 \\
\hline & & 0.01 & B01_07 \\
\hline & & 0.1 & B01_08 \\
\hline & \multirow{4}{*}{$-0.5 \$$} & 0.0001 & B01_09 \\
\hline & & 0.001 & B01_10 \\
\hline & & 0.01 & B01_11 \\
\hline & & 0.1 & B01_12 \\
\hline & \multirow{4}{*}{$-1.0 \$$} & 0.0001 & B01_13 \\
\hline & & 0.001 & B01_14 \\
\hline & & 0.01 & B01_15 \\
\hline & & 0.1 & B01_16 \\
\hline & \multirow{4}{*}{$-10.0 \$$} & 0.0001 & B01_17 \\
\hline & & 0.001 & B01_18 \\
\hline & & 0.01 & B01_19 \\
\hline & & 0.1 & B01_20 \\
\hline \multirow{8}{*}{$\begin{array}{l}\text { Ramp } \\
\text { insertion }\end{array}$} & \multirow{4}{*}{$0.1 \$ / \mathrm{s}$} & 0.0001 & B01_21 \\
\hline & & 0.001 & B01_22 \\
\hline & & 0.01 & B01_23 \\
\hline & & 0.1 & B01_24 \\
\hline & \multirow{4}{*}{$-0.1 \$ / \mathrm{s}$} & 0.0001 & B01_25 \\
\hline & & 0.001 & B01_26 \\
\hline & & 0.01 & B01_27 \\
\hline & & 0.1 & B01_28 \\
\hline \multicolumn{3}{|c|}{ Problem with feedback } & B01_29 \\
\hline
\end{tabular}




\section{Step Reactivity Changes}

Benchmarking solutions for step reactivity changes of $1 \$, 0.5 \$,-0.5 \$$ and $-1 \$$ have been published by Ganapol [9]. Comparisons with Ganapol's results revealed that, depending on the size of the time step, PARET/ANL was capable of greater precision than the ten significant figures published by Ganapol. To demonstrate this, the semi-analytic solution based on the Inhour equation [10] was evaluated. For this purpose, the roots of the Inhour equation were calculated with an approximate precision of 11 to 12 significant figures. The case numbers for step reactivity insertion test cases are listed in Table 3.1. Comparison of PARET/ANL solutions with the Inhour solutions for step reactivity changes of $1 \$, 0.5 \$,-0.5 \$,-1 \$$, and $-10 \$$ are shown in Table 3.2. To demonstrate the stability of the PARET/ANL solution, the $-0.5 \$$ and $-10 \$$ cases were extended to a time interval of 2.8 hours.

Table 3.2. Comparison of Solutions Obtained for Step Reactivity Insertions

\begin{tabular}{|c|c|c|c|c|c|c|c|c|c|}
\hline \multirow{2}{*}{$\begin{array}{c}\text { Time, } \\
s\end{array}$} & \multirow{2}{*}{$\begin{array}{l}\text { Inhour } \\
\text { Solution }\end{array}$} & \multicolumn{8}{|c|}{ PARET/ANL } \\
\hline & & $\Delta \mathrm{t}=10^{-1} \mathrm{~s}$ & Diff., \% & $\Delta t=10^{-2} \mathrm{~s}$ & Diff., \% & $\Delta \mathrm{t}=10^{-3} \mathrm{~s}$ & Diff., \% & $\Delta t=10^{-4} \mathrm{~s}$ & Diff., $\%$ \\
\hline \multicolumn{10}{|c|}{$1.0 \$$} \\
\hline 0.1 & $2.51576614140 \mathrm{E}+00$ & $2.51576612593 \mathrm{E}+00$ & $-6.1 \mathrm{E}-7$ & $2.51576611820 \mathrm{E}+00$ & $-9.2 \mathrm{E}-7$ & $2.51576614132 \mathrm{E}+00$ & $3.3 \mathrm{E}-9$ & $2.51576614140 \mathrm{E}+00$ & $-4.9 \mathrm{E}-12$ \\
\hline 0.5 & $1.03625338106 \mathrm{E}+01$ & $1.03625164208 \mathrm{E}+01$ & $-1.7 \mathrm{E}-4$ & $1.03625317858 \mathrm{E}+01$ & $-2.0 \mathrm{E}-5$ & $1.03625338083 \mathrm{E}+01$ & $-2.3 \mathrm{E}-8$ & $1.03625338106 \mathrm{E}+01$ & $-3.2 \mathrm{E}-11$ \\
\hline 1 & $3.21835409455 \mathrm{E}+01$ & $3.21806425169 \mathrm{E}+01$ & $-9.0 \mathrm{E}-3$ & $3.21835271598 \mathrm{E}+01$ & $-4.3 \mathrm{E}-5$ & $3.21835409306 \mathrm{E}+01$ & $-4.6 \mathrm{E}-8$ & $3.21835409455 \mathrm{E}+01$ & $-6.4 \mathrm{E}-11$ \\
\hline 10 & $3.24697889803 \mathrm{E}+09$ & $3.23487551238 \mathrm{E}+09$ & $-3.7 \mathrm{E}-1$ & $3.24696364864 \mathrm{E}+09$ & & $3.24697888244 \mathrm{E}+09$ & $-4.8 \mathrm{E}-7$ & $3.24697889801 E+09$ & $-6.6 \mathrm{E}-10$ \\
\hline 100 & $2.59648464655 \mathrm{E}+89$ & $2.49410096469 \mathrm{E}+89$ & $-3.9 \mathrm{E}+0$ & $2.59636137874 \mathrm{E}+89$ & $-4.7 \mathrm{E}-3$ & $2.59648452118 \mathrm{E}+89$ & $-4.8 \mathrm{E}-6$ & $2.59648464638 \mathrm{E}+89$ & $-6.6 \mathrm{E}-9$ \\
\hline \multicolumn{10}{|c|}{$0.5 \$$} \\
\hline 0.1 & $1.53311264595 \mathrm{E}+00$ & $1.53311254579 \mathrm{E}+00$ & $-6.5 \mathrm{E}-6$ & $1.53311256171 \mathrm{E}+00$ & $-5.5 \mathrm{E}-6$ & $1.53311264580 \mathrm{E}+00$ & $-9.7 \mathrm{E}-9$ & $1.53311264595 \mathrm{E}+00$ & $-1.2 \mathrm{E}-11$ \\
\hline 1 & $2.51149429149 \mathrm{E}+00$ & $2.51138523745 \mathrm{E}+00$ & $-4.3 \mathrm{E}-3$ & $2.51149405604 \mathrm{E}+00$ & $-9.4 \mathrm{E}-6$ & $2.51149429123 \mathrm{E}+00$ & $-1.0 \mathrm{E}-8$ & $2.51149429149 \mathrm{E}+00$ & $-1.1 \mathrm{E}-11$ \\
\hline 10 & 1.42 & 1.42 & $-1.9 \mathrm{E}-2$ & $1.42150214663 \mathrm{E}+01$ & & +01 & $-2.8 \mathrm{E}-8$ & $424 \mathrm{E}+01$ & $-4.1 \mathrm{E}-11$ \\
\hline 100 & $8.00614356244 \mathrm{E}+07$ & $7.99352367659 \mathrm{E}+07$ & $-1.6 \mathrm{E}-1$ & $8.00612709794 \mathrm{E}+07$ & & $\mathrm{E}+07$ & $-2.1 \mathrm{E}-7$ & $242 \mathrm{E}+07$ & $-2.1 \mathrm{E}-10$ \\
\hline \multicolumn{10}{|c|}{$-0.5 \$$} \\
\hline 0.1 & $1 \mathrm{E}-01$ & 6.98 & $6.6 \mathrm{E}-6$ & $6.98925264480 \mathrm{E}-01$ & $5.6 \mathrm{E}-6$ & $\mathrm{E}-01$ & $1.4 \mathrm{E}-8$ & $1 \mathrm{E}-01$ & $1.4 \mathrm{E}-11$ \\
\hline 1 & 6.07053565606E-01 & $6.07059473800 \mathrm{E}-01$ & $9.7 \mathrm{E}-4$ & $6.07053578449 \mathrm{E}-01$ & $2.1 \mathrm{E}-6$ & $6.07053565624 \mathrm{E}-01$ & $2.9 \mathrm{E}-9$ & $6.07053565606 \mathrm{E}-01$ & $-4.4 \mathrm{E}-12$ \\
\hline 10 & 3.96 & 3.96 & $1.0 \mathrm{E}-3$ & 3.9 & & & $2.3 \mathrm{E}-9$ & & $-1.3 \mathrm{E}-10$ \\
\hline 100 & 7.158 & 7.15 & $1.1 \mathrm{E}-3$ & $7.15828558259 \mathrm{E}-02$ & $E-6$ & -02 & $2.1 \mathrm{E}-9$ & $\mathrm{E}-02$ & $-1.2 \mathrm{E}-10$ \\
\hline 1000 & $1.49213247261 \mathrm{E}-06$ & $1.49215770511 \mathrm{E}-06$ & $1.7 \mathrm{E}-3$ & $1.49213251819 \mathrm{E}-06$ & $3.1 \mathrm{E}-6$ & $1.49213247265 \mathrm{E}-06$ & $2.8 \mathrm{E}-9$ & $1.49213247261 \mathrm{E}-06$ & $-1.0 \mathrm{E}-10$ \\
\hline \multicolumn{10}{|c|}{$-1.0 \$$} \\
\hline 0.1 & 5.20564286609E-01 & $5.20564302610 \mathrm{E}-01$ & $3.1 \mathrm{E}-6$ & 5.20564311673E-01 & $4.8 \mathrm{E}-6$ & 5.20564286731E-01 & $2.4 \mathrm{E}-8$ & \begin{tabular}{|l}
$5.20564286609 \mathrm{E}-01$ \\
\end{tabular} & $2.4 \mathrm{E}-11$ \\
\hline 1 & $15301 \mathrm{E}-01$ & 4.333 & $1.2 \mathrm{E}-3$ & 56715E-01 & & & $4.2 \mathrm{E}-9$ & -01 & $-5.2 \mathrm{E}-12$ \\
\hline 10 & 2.36 & 2.36 & $9.6 \mathrm{E}-4$ & $555566 \mathrm{E}-01$ & $2.0 \mathrm{E}-6$ & 2.3 & $2.7 E-9$ & E-01 & $-1.2 \mathrm{E}-10$ \\
\hline 100 & $2.86676424545 \mathrm{E}-02$ & 2.86678355664E-02 & $6.7 E-4$ & $2.86676428550 \mathrm{E}-02$ & $1.4 \mathrm{E}-6$ & $2.86676424550 \mathrm{E}-02$ & $1.7 E-9$ & 2.86676424544E-02 & $-1.1 \mathrm{E}-10$ \\
\hline \multicolumn{10}{|c|}{$-10.0 \$$} \\
\hline 0.01 & $2.65423744138 \mathrm{E}-01$ & - & & $2.65423745175 \mathrm{E}-01$ & $3.9 \mathrm{E}-7$ & $2.65423745433 \mathrm{E}-01$ & $4.9 \mathrm{E}-7$ & \begin{tabular}{|l|}
$2.65423744140 \mathrm{E}-01$ \\
\end{tabular} & $8.1 \mathrm{E}-10$ \\
\hline 0.1 & $8.79467364532 \mathrm{E}-02$ & 8.794675992 & $2.7 \mathrm{E}-5$ & $8.79467396575 \mathrm{E}-02$ & $3.6 \mathrm{E}-6$ & $8.79467364848 \mathrm{E}-02$ & $3.6 \mathrm{E}-8$ & \begin{tabular}{|l|l|}
$8.79467364532 \mathrm{E}-02$ \\
\end{tabular} & $1.6 \mathrm{E}-11$ \\
\hline 0.5 & 7.78700077417E-02 & $7.78700925973 \mathrm{E}-02$ & $1.1 \mathrm{E}-4$ & $7.78700101857 \mathrm{E}-02$ & $3.1 \mathrm{E}-6$ & 7.78700077627E-02 & $2.7 \mathrm{E}-8$ & $7.78700077418 \mathrm{E}-02$ & $9.4 \mathrm{E}-12$ \\
\hline 1 & 6.94112428147E-02 & $6.94113725364 \mathrm{E}-02$ & $1.9 \mathrm{E}-4$ & 6.94112446998E-02 & $2.7 \mathrm{E}-6$ & 6.94112428297E-02 & $2.2 \mathrm{E}-8$ & \begin{tabular}{|l|}
$6.94112428147 \mathrm{E}-02$ \\
\end{tabular} & $3.2 \mathrm{E}-12$ \\
\hline 10 & $2.65443026189 \mathrm{E}-02$ & $2.65443324285 \mathrm{E}-02$ & $1.1 \mathrm{E}-4$ & $2.65443029122 \mathrm{E}-02$ & $1.1 \mathrm{E}-6$ & $2.65443026208 \mathrm{E}-02$ & $7.2 \mathrm{E}-9$ & $2.65443026189 \mathrm{E}-02$ & $-7.2 \mathrm{E}-11$ \\
\hline 100 & $2.05500634866 \mathrm{E}-03$ & $2.05500719307 \mathrm{E}-03$ & $4.1 \mathrm{E}-5$ & $2.05500635638 \mathrm{E}-03$ & $3.8 \mathrm{E}-7$ & $2.05500634870 \mathrm{E}-03$ & $2.2 \mathrm{E}-9$ & $2.05500634866 \mathrm{E}-03$ & $-5.0 \mathrm{E}-11$ \\
\hline 1000 & $1.25870180432 \mathrm{E}-08$ & $1.25870213689 \mathrm{E}-08$ & $2.6 \mathrm{E}-5$ & $1.25870180726 \mathrm{E}-08$ & $2.3 \mathrm{E}-7$ & $1.25870180433 \mathrm{E}-08$ & $1.3 \mathrm{E}-9$ & $1.25870180432 \mathrm{E}-08$ & $-4.7 \mathrm{E}-11$ \\
\hline
\end{tabular}

Examination of the results in Table 3.2 shows that for the larger time steps of 0.1 and $0.01 \mathrm{~s}$, the differences are smaller over the first few tenths of a second than at greater times. For these larger time steps, the PARET/ANL point kinetics algorithm iteratively subdivides the time step until a more accurate solution is obtained. In the $1 \$$ step insertion problem such iterations continue throughout nearly the first second of the transient. A few such iterations occur during the first time step even with the time step size of $0.001 \mathrm{~s}$. For the other cases in Table 3.2, the iterations cease by a transient time of $0.5 \mathrm{~s}$ or less. While the high accuracy indicated in the table for time step sizes of 0.001 and $0.0001 \mathrm{~s}$ is of academic interest, such accuracy is not required in practical calculations. The results in the table show that very accurate solutions can be expected even for the larger time step size of 0.01 S. 


\section{Ramp Reactivity Insertions}

As mentioned above, Table 3.1 includes test cases for the ramp reactivity insertion results. In addition to the step reactivity insertions referenced above, Ganapol [9] also published a benchmark solution to the point kinetics equations for a ramp reactivity insertion of $0.1 \$ / \mathrm{s}$. The PARET/ANL solution to this case is compared with Ganapol's result in Table 3.3. The results shown indicate that PARET/ANL provides an accurate solution for this case with the larger time step size of $0.01 \mathrm{~s}$. Also included in Table 3.3 are results for a ramp reactivity insertion of $-0.1 \$ / \mathrm{s}$. A benchmark solution was not available for this case, but the GEAR solution method [11] has been used at Argonne for many years for point kinetics problems as well as for other problems. It was applied to the step problems in Table 3.2 and to the $0.1 \$ / \mathrm{s}$ ramp problem in Table 3.3. Using functional iteration and very tight convergence, the GEAR solutions were found to be very accurate for the published step and ramp benchmarks. The PARET/ANL results are compared with the GEAR solution for the $-0.1 \$ / \mathrm{s}$ case in Table 3.3. As indicated in the table, excellent agreement was found between the GEAR and PARET/ANL solutions.

Table 3.3. Comparison of Solutions Obtained for Ramp Reactivity Insertions

\begin{tabular}{|c|c|c|c|c|c|c|c|c|c|}
\hline \multirow[b]{2}{*}{$\begin{array}{c}\text { Time, } \\
\mathbf{S}\end{array}$} & \multirow[b]{2}{*}{ Reference } & \multicolumn{8}{|c|}{ PARET/ANL } \\
\hline & & $\Delta t=10^{-1} \mathrm{~s}$ & \begin{tabular}{|c|} 
Diff., \\
$\%$ \\
\end{tabular} & $\Delta \mathrm{t}=10^{-2} \mathrm{~s}$ & \begin{tabular}{|c} 
Diff., \\
$\%$
\end{tabular} & $\Delta t=10^{-3} \mathrm{~s}$ & \begin{tabular}{|c|} 
Diff., \\
$\%$ \\
\end{tabular} & $\Delta t=10^{-4} \mathrm{~s}$ & \begin{tabular}{|c} 
Diff., \\
$\%$
\end{tabular} \\
\hline $0.1 \$ / \mathrm{s}$ & Ganapol & & & & & & & & \\
\hline 2.0 & $1.338200050 \mathrm{E}+00$ & $1.33811150 \mathrm{E}+00$ & $-6.6 \mathrm{E}-3$ & $1.33819924 \mathrm{E}+00$ & $-6.1 \mathrm{E}-5$ & $1.33820005 \mathrm{E}+0$ & $0.0 \mathrm{E}+0$ & $1.33820005 \mathrm{E}+0$ & $0.0 \mathrm{E}+0$ \\
\hline 4.0 & $2.228441897 \mathrm{E}+00$ & $2.22793320 \mathrm{E}+00$ & $-2.3 \mathrm{E}-2$ & $2.22843841 \mathrm{E}+00$ & $-1.6 \mathrm{E}-4$ & $2.22844189 \mathrm{E}+0$ & $-3.1 \mathrm{E}-7$ & $2.22844190 \mathrm{E}+0$ & $1.3 \mathrm{E}-7$ \\
\hline 6.0 & $5.582052449 \mathrm{E}+00$ & $5.57727954 \mathrm{E}+00$ & $-8.6 \mathrm{E}-2$ & $5.58202830 \mathrm{E}+00$ & $-4.3 \mathrm{E}-4$ & $5.58205241 \mathrm{E}+0$ & $-7.0 \mathrm{E}-7$ & $5.58205245 \mathrm{E}+0$ & $1.8 \mathrm{E}-8$ \\
\hline 8.0 & $4.278629573 E+01$ & $4.25655601 \mathrm{E}+01$ & $-5.2 \mathrm{E}-1$ & $4.27855585 \mathrm{E}+01$ & $-1.7 \mathrm{E}-3$ & $4.27862948 \mathrm{E}+1$ & $-2.2 \mathrm{E}-6$ & $4.27862957 \mathrm{E}+1$ & $-7.0 \mathrm{E}-8$ \\
\hline 10.0 & $4.511636239 \mathrm{E}+05$ & $4.48163388 \mathrm{E}+05$ & $-6.6 \mathrm{E}-1$ & 4.51074537E+05 & $-2.0 \mathrm{E}-2$ & $4.51163526 \mathrm{E}+05$ & $-2.2 \mathrm{E}-5$ & $4.51163624 \mathrm{E}+05$ & $2.2 \mathrm{E}-8$ \\
\hline 11.0 & $1.792213607 \mathrm{E}+16$ & $1.78003939 \mathrm{E}+16$ & $-6.8 \mathrm{E}-1$ & $1.79178130 \mathrm{E}+16$ & $-2.4 \mathrm{E}-2$ & $1.79221320 \mathrm{E}+16$ & $-2.3 \mathrm{E}-5$ & $1.79221361 \mathrm{E}+16$ & $1.7 \mathrm{E}-7$ \\
\hline$-0.1 \$ / s$ & GEAR & & & & & & & & \\
\hline 2.0 & 7.920047774E-01 & 7.92016185E-01 & $1.4 \mathrm{E}-3$ & 7.92004998E-01 & $2.8 \mathrm{E}-5$ & $7.92004778 \mathrm{E}-01$ & $8.0 \mathrm{E}-8$ & 7.92004777E-01 & $-4.6 \mathrm{E}-8$ \\
\hline 4.0 & $6.130158504 \mathrm{E}-01$ & 6.13026669E-01 & $1.8 \mathrm{E}-3$ & 6.13016044E-01 & $3.2 \mathrm{E}-5$ & $6.13015851 \mathrm{E}-01$ & $1.0 \mathrm{E}-7$ & $6.13015850 \mathrm{E}-01$ & $-6.0 \mathrm{E}-8$ \\
\hline 6.0 & 4.740567389E-01 & 4.74065598E-01 & $1.9 \mathrm{E}-3$ & 4.74056891E-01 & $3.2 \mathrm{E}-5$ & 4.74056739E-01 & $1.4 \mathrm{E}-8$ & 4.74056739E-01 & $1.4 \mathrm{E}-8$ \\
\hline 8.0 & 3.691679393E-01 & 3.69174796E-01 & $1.9 \mathrm{E}-3$ & 3.69168053E-01 & $3.1 \mathrm{E}-5$ & 3.69167940E-01 & $1.8 \mathrm{E}-7$ & 3.69167939E-01 & $-9.2 \mathrm{E}-8$ \\
\hline 10.0 & $2.906533723 \mathrm{E}-01$ & $2.90658552 \mathrm{E}-01$ & $1.8 \mathrm{E}-3$ & $2.90653456 \mathrm{E}-01$ & $2.9 \mathrm{E}-5$ & $2.90653373 \mathrm{E}-01$ & $2.3 \mathrm{E}-7$ & $2.90653372 \mathrm{E}-01$ & $-1.1 \mathrm{E}-7$ \\
\hline 12.0 & 2.317971695E-01 & $2.31801051 \mathrm{E}-01$ & $1.7 \mathrm{E}-3$ & $2.31797231 \mathrm{E}-01$ & $2.7 \mathrm{E}-5$ & $2.31797170 \mathrm{E}-01$ & $2.0 \mathrm{E}-7$ & $2.31797170 \mathrm{E}-01$ & $2.0 \mathrm{E}-7$ \\
\hline 100.0 & $2.547385731 \mathrm{E}-03$ & $2.54739834 \mathrm{E}-03$ & $4.9 \mathrm{E}-4$ & $2.54738589 \mathrm{E}-03$ & $6.3 \mathrm{E}-6$ & $2.54738573 \mathrm{E}-03$ & $-2.4 \mathrm{E}-8$ & $2.54738573 \mathrm{E}-03$ & $-2.4 \mathrm{E}-8$ \\
\hline 1000.0 & 1.342156214E-09 & 1.34216004E-09 & $2.9 \mathrm{E}-4$ & 1.34215626E-09 & $3.5 \mathrm{E}-6$ & 1.34215621E-09 & $\mid-2.6 \mathrm{E}-7$ & $1.34215621 \mathrm{E}-09$ & $-2.6 \mathrm{E}-7$ \\
\hline
\end{tabular}

\section{Problem with Feedback}

The PARET/ANL model for reactivity insertion accident analysis for an operating research reactor served as the basis for a verification problem involving reactivity feedback. In this case, designated test case B01_29, the external reactivity shown in Figure 3.1was imposed in the PARET/ANL model. The imposed reactivity postulates a reactivity insertion of $0.1 \$ / \mathrm{s}$ over the first second of the transient. At one second, a step reactivity insertion occurs, taking the imposed reactivity from $0.1 \$$ to $0.784 \$$. For the next half second, the imposed reactivity is held constant at $0.784 \$$. Then the imposed reactivity steps down to $0 \$$, and from 1.5 to $2 \mathrm{~s}$ the imposed reactivity decreases linearly from 0 to -10 \$. Rather than trying to use GEAR to reconstruct the reactivity feedback from associated from the effects of the imposed reactivity, the imposed reactivity was subtracted from the net reactivity calculated by PARET/ANL. The feedback reactivity so obtained is shown in Figure 3.2. A GEAR solution to the problem was run using the imposed reactivity shown in Figure 3.1and feedback reactivity interpolated from the table of values used to construct the curve shown in Figure 3.2. The resulting reactor power, including $0.76806 \mathrm{MW}$ of decay heat, is shown as a function of time in Figure 
3.3. The legend in the figure indicates that both the PARET/ANL and GEAR solutions are shown, but, as is apparent from the plot, the two solutions are indistinguishable from each other. By requiring the GEAR solution to produce the power at the same times for which PARET/ANL reported the power, it was possible to make a time-point by time-point comparison between the two calculations. The largest percent difference between the two calculations is $0.13 \%$. This difference occurs near 1.5 seconds where the power is decreasing very rapidly.

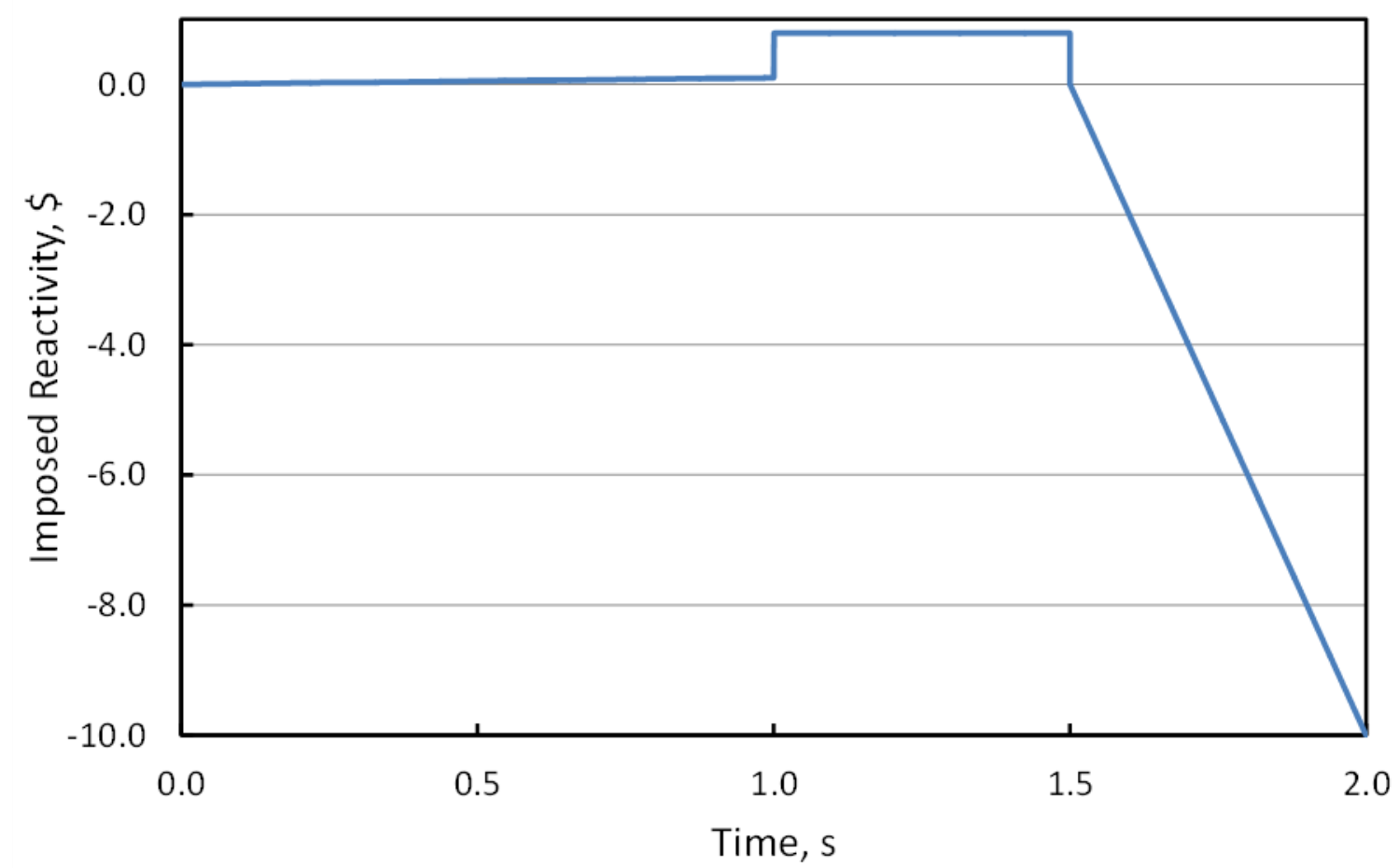

Figure 3.1. Imposed Reactivity for The Verification Problem with Feedback. 


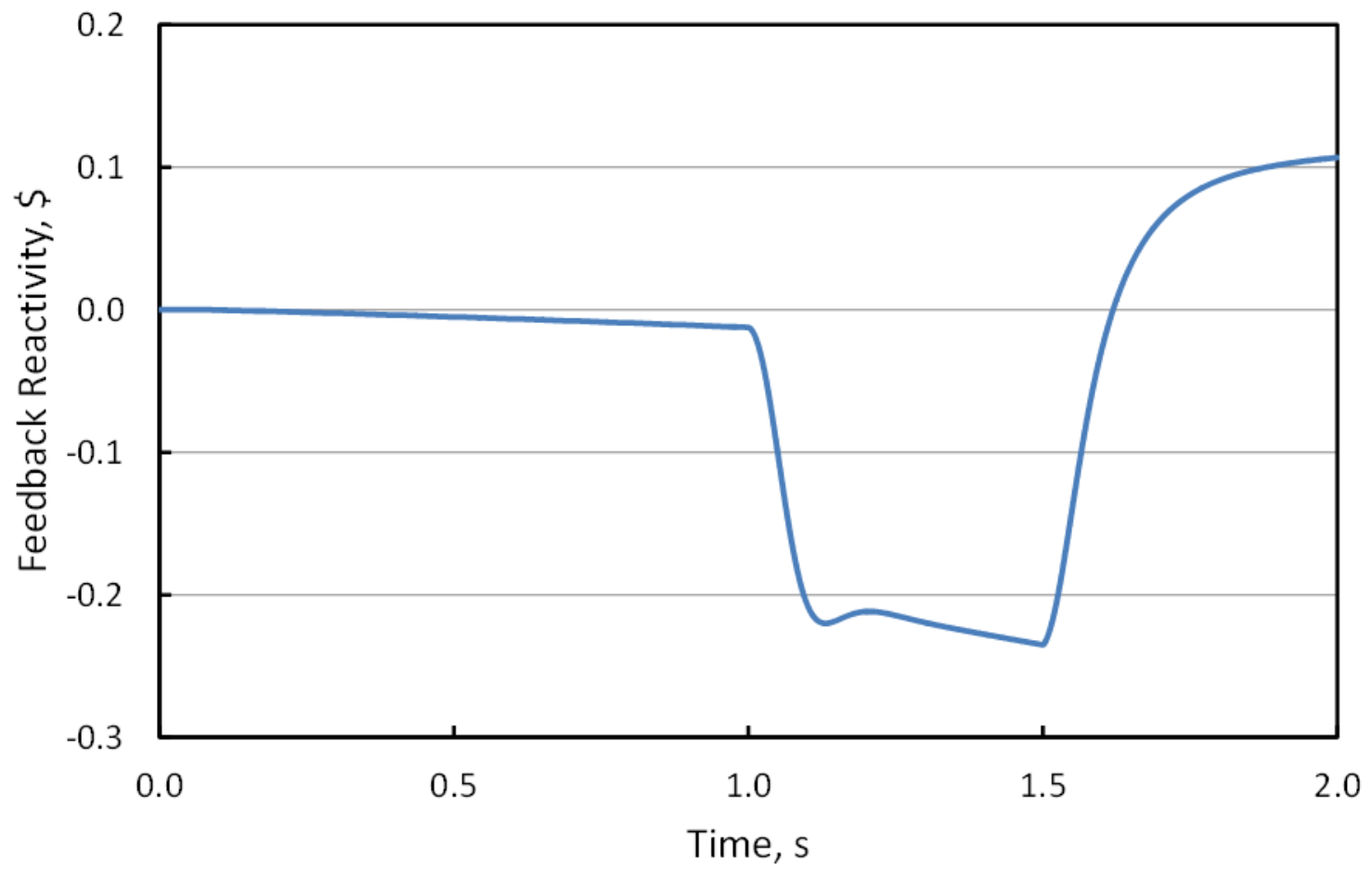

Figure 3.2. Feedback Reactivity for the Verification Problem with Feedback.

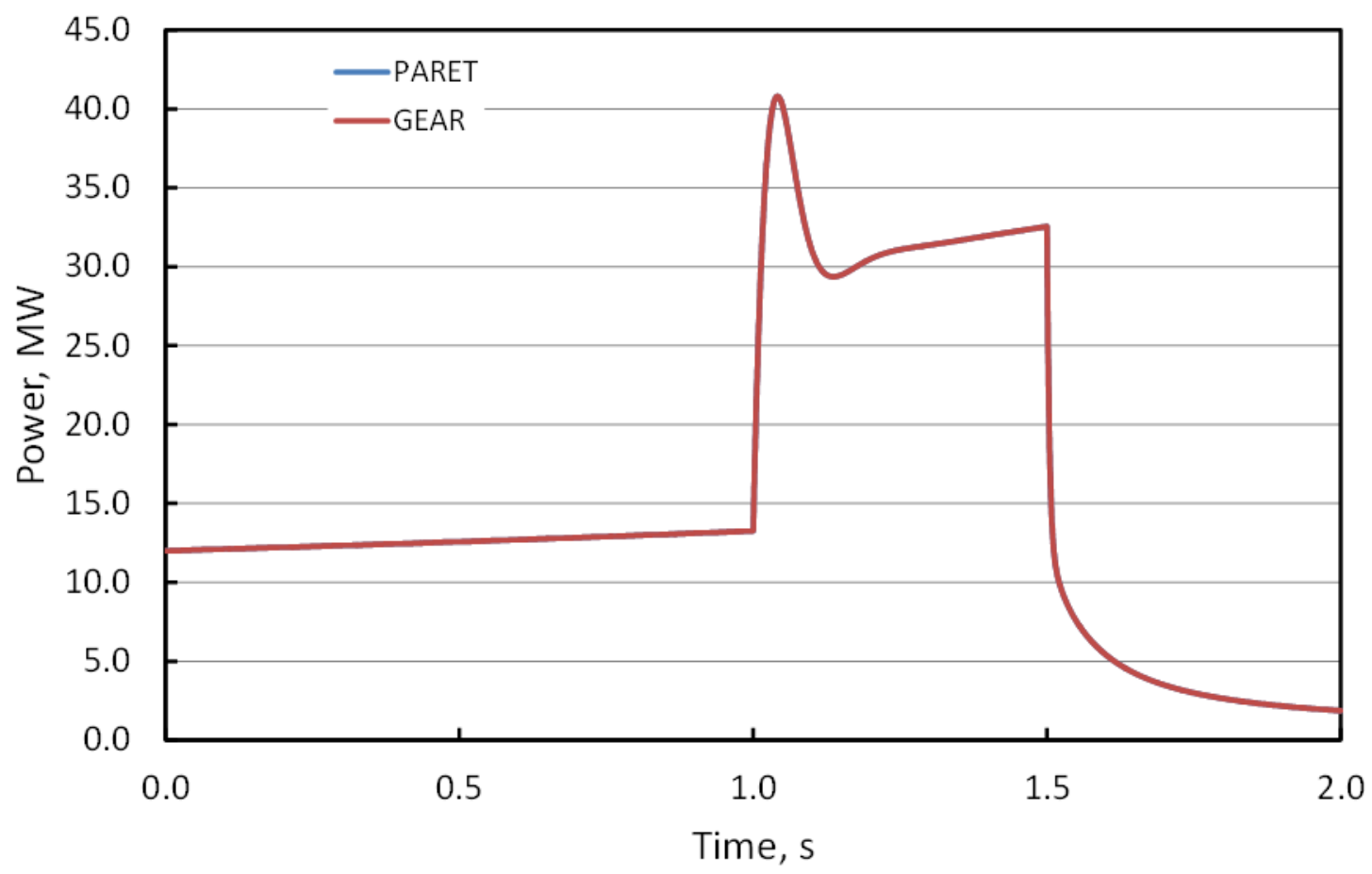

Figure 3.3. Reactor Power for the Verification Problem with Feedback. 


\subsection{Capability B2 - Reactivity Feedback}

PARET/ANL is capable of handling the reactivity feedback including the impact of the axial dependence of the power density. This Section documents a series of test problems that enable checking the functionality of the reactivity feedback profiles given in variables VOIDVC and TEMPC. Reactivity feedback from coolant void is computed and scaled by the value of VOIDVC in each fluid axial mesh interval. The profile TEMPC scales the reactivity feedback from coolant temperature changes in each fluid axial mesh interval. Likewise, the profile from DOPPLR scales the fuel temperature Doppler effect from each fuel meat mesh interval.

Additionally, the verification of reactivity feedback due to the thermal expansion of fuel plates is also included. PARET/ANL input cards 11xxx are used in the calculation of linear thermal expansion of fuel plate cladding. The fuel plates in typical plate-type fuel assemblies can expand radially from nearinstantaneous heat-up during a reactivity transient. When this occurs, there is a loss of coolant channel cross section area which amounts to causing a loss of moderation. The edges of the fuel plates may be confined in side plates that do not heat up as quickly as do the heated plate sections. The PARET/ANL model for thermal expansion of clad makes the assumption that there is essentially no heat transfer from the heated meat section to the side plates during a short transient. The same assumption applies to grid plates that define the spacing of the fuel assemblies. Therefore the side plate dimensions and fuel assembly pitch remain fixed over a rapid transient. PARET/ANL input cards $11 \mathrm{xxx}$ contains the linear thermal expansion of the cladding material in percent as a function of temperature. The table is piecewise linear. It is supplied as \% linear thermal expansion at a series of temperatures which must span the temperature range expected. The expansion is computed at every time step using the radial average temperature of the cladding in every axial node in every channel.

As discussed in the following subsections, PARET/ANL processes correctly the reactivity feedback due to the change of moderator density, fuel temperature, and thermal expansion.

\subsubsection{Testing of Moderator Reactivity Feedback Test Plan}

The first set of calculations shall be performed for five conditions. In all cases, reactivity feedback derived from coolant void (density) changes or coolant temperature changes using input related to the reactivity feedback coefficients is computed. From input cards 5xxx, DVOID is the overall density/void coefficient. VOIDVC is the dimensionless coolant density feedback weighting factor at each axial node. DTMP is the feedback reactivity coefficient. TEMPC is the dimensionless coolant temperature feedback weighting factor at each axial node. Each case is defined as follows:

Case B02_01: Define a reference case from a standard test case which has an axial profile defined for each of VOIDVC and TEMPC.

Case B02_02: Change the axial profiles for VOIDVC, DOPPLR, and TEMPC to a flat profile (all values = 1.0 ), to eliminate the weighting factor effect.

Case B02_03: Scale the axial profiles by a factor of 2 for VOIDVC, DOPPLR, and TEMPC.

Case B02_04: Isolate the reactivity change to that from TEMPC and DOPPLR.

Case B02_05: Isolate the reactivity change due to using the axial profile from Case B02_01 only on the VOIDC input. 
The expected results of interest are:

1. The moderator reactivity effect from expansion and void changes should be the same (within a small numerical tolerance) for Case B02_01 and Case B02_05.

2. The moderator reactivity effect from coolant expansion and void changes for Case B02_03 should be double (within a small numerical tolerance) that of Case B02_02.

3. The moderator reactivity effect from coolant temperature changes for Case B02_03 should be double (within a small numerical tolerance) that of Case B02_02, because the axial weighting factor is doubled.

4. The effect of the perturbation weighting (which enhances core axial mid-plane worths over top or bottom worths) of Case B02_02 vs. Case B02_03 should show slightly lower peak power, peak fuel centerline temperature, and peak cladding temperature.

5. Case B02_03 should have the lowest peak power, because it has the most reactivity feedback from temperature, void, and Doppler Effects. It should also have the lowest peak fuel centerline temperature, and peak cladding temperature.

Note: The comparisons shall be made at a time of 10.135 seconds into the transient. This time was found by observing that this is the time of the major edit near to the scram time where the three feedback effects are at their maxima. At later times, the control rods have begun insertion and the power is quickly reduced. Reactivity feedback terms are also quickly reduced. One must keep in mind that PARET/ANL initializes the feedback terms to zero at time zero. This physically corresponds to the assumption that the reactor is critical and in steady-state at time zero. If the reactor at time zero is at significant power, then there will be a reactivity offset computed at time zero that will automatically be compensated for. As the reactor first heats up and then cools down, one may observe in the major edit how the various feedback terms change.

Acceptance of these tests requires that the output from Cases 98 and 99 be consistent and in agreement at TIME $t=0.0$ seconds. The coolant exit temperatures in channel 1 at $0.0 \mathrm{sec}$ should agree within $0.02 \mathrm{C}$, in order to assure that the same coolant average density is attained. The reactivity feedback at 0.0 sec should be zero.

\section{Results and Discussion}

Results from varying the input axial profile data for variables affecting the computation of the reactivity feedback are presented in Table 3.4. The primary output file results show that the coolant exit temperature in channel 1 at time $t=0$ is the same for all cases. The value is $53.9443{ }^{\circ} \mathrm{C}$. As expected, the feedback reactivity was shown to be $0.0 \$$. 
Table 3.4. Calculation Results

\begin{tabular}{|c|c|c|c|c|c|}
\hline Test Case & B02_01 & B02_02 & B02_03 & B02_04 & B02_05 \\
\hline Peak Power, MW & 13.17 & 13.18 & 13.14 & 13.16 & 13.18 \\
\hline Time of Power Peak, s & 10.090 & 10.090 & 10.090 & 10.090 & 10.090 \\
\hline Energy Release to time of Peak, MWs & 101.09 & 101.08 & 101.12 & 101.11 & 101.08 \\
\hline Fuel Max. $\mathrm{T},{ }^{\circ} \mathrm{C}$ & 81.221 & 81.225 & 81.209 & 81.216 & 81.224 \\
\hline Clad Max $\mathrm{T},{ }^{\circ} \mathrm{C}$ & 79.234 & 79.237 & 79.222 & 79.229 & 79.221 \\
\hline Trip Time, $\mathrm{s}$ & 10.0636 & 10.0636 & 10.0637 & 10.0636 & 10.0636 \\
\hline $\begin{array}{l}\text { Reactivity change from Moderator Expansion \& } \\
\text { Void, } \$ \text { at } t=10.135 \mathrm{~s}\end{array}$ & 0.00428 & 0.00376 & 0.00751 & 0.00376 & 0.00428 \\
\hline $\begin{array}{l}\text { Reactivity Change from Moderator Temperature, } \\
\$ \text { at } t=10.135 \mathrm{~s}\end{array}$ & 0.00529 & 0.00455 & 0.00909 & 0.00910 & 0.00455 \\
\hline
\end{tabular}

The checking of expected results from this series of tests are as follows:

1. The moderator reactivity effect from expansion and void changes should be the same (within a small numerical tolerance) for Case B02_01 and Case B02_05.

Yes, the same moderator reactivity of 0.00428 \$ for both Cases B02_01 and B02_05.

2. The moderator reactivity effect from expansion and void changes for Case B02_03 should be double (within a small numerical tolerance) that of Case B02_02.

Yes, predicted ratio is $0.00751 / 0.00376=1.99734$, a difference of $0.13 \%$.

3. The moderator reactivity effect from temperature changes for Case B02_03 should be double (within a small numerical tolerance) that of Case B02_02, because the axial weighting factor is doubled.

Yes, predicted ratio is $0.00909 / 0.00455=1.99780$, a difference of $0.11 \%$.

4. The effect of the perturbation weighting (which enhances core axial mid-plane worths over top or bottom worths) of Case B02_02 vs. Case B02_03 show slightly lower peak power, peak fuel centerline temperature, and peak clad temperature.

Yes, a very small effect.

5. Expect that Case B02_03 should have the lowest peak power, because it has the most reactivity feedback from temperature and void effects. It should also have the lowest peak fuel centerline temperature, and peak clad temperature.

Yes, 13.14 MW is the lowest. The peak fuel and clad temperatures from Case B02_03 are very slightly lower than from all other cases, as expected. 


\section{Conclusion}

These tests confirm that the code computes two reactivity feedback effects (coolant density/void, coolant temperature) consistent with expectations when scaled by an axial worth shape factor. The Doppler feedback also approximately doubles but has too few significant digits to be obvious (0.00002 vs 0.00005$)$.

\subsubsection{Testing of Doppler Feedback}

\section{Test Plan}

In research reactors fueled by uranium, the presence of resonance neutron absorbers such as U-238 may have a significant effect on reactor core excess reactivity. Neutron absorption by resonances for neutron energies above thermal (approximately the eV-keV range) depends on the fuel meat temperature. The neutron absorption increases with fuel meat temperature. The reactivity effect caused by resonance capture is called the Doppler effect.

The description and analysis of the SPERT-III tests is described in Refs. [12], [13], [14], and [15]. This set of calculations shall be performed for three scenarios. In all cases, compute reactivity feedback derived from input cards 5xxx, DVOID, VOIDVC, DOPPLR, and the Doppler feedback equation given in Section 5.8 of the PARET/ANL User's Manual [2]. That equation uses variables GAMMA0, GAMMA1, GAMMA2, GAMMA3, GAMMA4, and DOPPNK. This present work shall qualify the Doppler effect equation for a linear variation of feedback reactivity with temperature, using GAMMA1 only. The GAMMA0 term can be used to set the feedback at $\mathrm{t}=0$. It has no effect on any results, and is therefore recommended to be set to zero. The terms GAMMA2, GAMMA3, GAMMA4, and DOPPNK shall be set to 0 .

As the code prints out the average composition temperatures at the end of the last major edit, just before the problem terminates, a reference test case is run with different transient times as follows: Case B02_06: Define a reference case from a standard SPERT-III test case (use Test T-82) which uses fuel rods modeled using IGEOM=1. It has an axial profile defined for each of VOIDVC, DOPPLR, and TEMPC. This case will be a reactivity-insertion transient to take the core average fuel temperature well above initial hot, full power conditions in steady-state. The linear term of the Doppler Feedback equation was input as $0.002552 \$ /{ }^{\circ} \mathrm{C}$, obtained from an MCNP model analysis. Higher-order terms were all input as zero coefficients.

Case B02_07: Change the transient time to the time from Case B02_06 where the power peak occurs. Case B02_08: Change the transient time to 0.001 second, near enough to the initial conditions.

\section{Results and Discussion}

Case B02_06 was run to 0.2501 seconds. The power peak was $1558.93 \mathrm{MW}$ at 0.1243 seconds. At this time step, the Doppler feedback reactivity was $0.17768 \$$.

Case B02_07 was run to 0.12430 seconds, which is the time the power peak of 1558.93 MW was reached in Case B02_06. The edit just before the end of the standard output showed: 


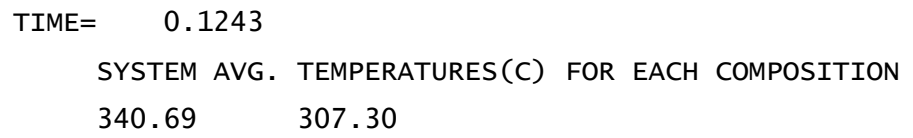

Note that the "340.69" temperature listed above is for the first composition, which is always the fuel meat.

Case B02_08 was run to 0.001 seconds in order to obtain system temperatures at the beginning of the transient. The edit just before the end of the standard output showed:

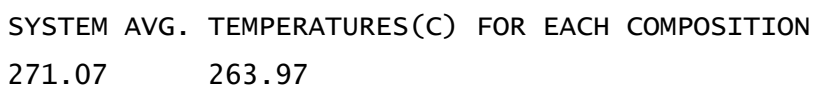

Using the reported average fuel temperatures at $0.001 \mathrm{~s}$ (Case B02_08) and 0.1243 s (Case B02_07), and the input linear term of the Doppler feedback equation, a simple hand calculation of expected reactivity change from Doppler effect alone:

$$
\text { Reactivity change }(\$)=0.002552 *(340.69-271.07)=0.002552 * 69.62=0.17767 \$ \text {. }
$$

Obtained results agrees extremely well with the Doppler effect reactivity reported by the code as 0.17768 \$.

It is important to realize that this result is from a 5-channel model with 20 axial fuel zones by 5 radial fuel zones. It has 5 complex axial power shapes with a peak/average ratio up to 2.87 in the mostpeaked channel. All 5 channels have a different axial power profile. In order to match the hand calculation of reactivity feedback, the code must consistently compute the contributions to that feedback for 5 channels, times 20 axial nodes, times 5 radial nodes in the fuel meat.

\section{Conclusion}

These cases verify that the Doppler Effect equation in PARET/ANL is correct for the linear term based on GAMMA1. That is the form used in standard core analysis.

\subsubsection{Testing of Feedback due to Thermal Expansion Test plan}

Note that the methodology for computing the expansion feedback is essentially the same for the IGEOM $=2$ option as it is for the IGEOM=0 option. The geometry variable IGEOM is 0 for slab geometry for the fuel plate and channel. It is 1 for cylindrical geometry. It is 2 for slab geometry where the channel dimensions can be changed by channel. Precise definitions for the IGEOM options are given in Section 5.8 of the User Guide [2]. For IGEOM=1, the "effective coolant channel thickness" is obtained in the same way as for slabs by dividing the channel volume by the clad surface area. Calculations were performed in slab geometry $(\mathrm{IGEOM}=0)$ with the radial dimension across the fuel plate thickness specified by Table 3.5 . 
Table 3.5. Radial Dimensions

\begin{tabular}{|c|l|c|}
\hline $\begin{array}{c}\text { Input } \\
\text { Parameter }\end{array}$ & \multicolumn{1}{|c|}{ Description } & Value, $\mathbf{~}$ \\
\hline RF & Radial distance to outer surface of the fuel meat & $2.55 \mathrm{E}-4$ \\
\hline RC & Radial distance to inner surface of the clad & $2.55 \mathrm{E}-4$ \\
\hline RS & Radial distance to outer surface of the clad & $6.35 \mathrm{E}-4$ \\
\hline RN & $\begin{array}{l}\text { The radial distance from the center of the rod to the } \\
\text { center of the water channel }\end{array}$ & $1.75 \mathrm{E}-3$ \\
\hline
\end{tabular}

Doppler and temperature feedback were zeroed, leaving only expansion feedback derived from PARET/ANL input cards 11xxx, the overall density or void coefficient (DVOID) specified by input card $5 \mathrm{xxx}$, and other geometric factors. It was not possible to turn off the usual void coefficient calculation by simply setting DVOID and VOIDVC to zero because the reactivity effect of expansion needs those quantities. Instead, in order to isolate the feedback from rod expansion, it was necessary to introduce a positive reactivity effect that would compensate for the negative feedback for moderator expansion and void alone. The remaining feedback would then be just from rod expansion. The test cases are as follows:

Case B02_09: A standard IAEA test case for 1.50 \$ insertion, was run to 0.6400 seconds. There is an edit of core-average meat and cladding temperatures at the very end of the standard output. Those temperatures are needed to check the thermal expansion. The input card 5xxx gave the moderator expansion and void coefficient of $0.2357 \$ / \%$ void. The input cards $11 x x x$ gave a thermal expansion linearly with temperature of $4.0701 \mathrm{E}-3 \%$ per degree K. Since input cards $11 \mathrm{xxx}$ include a zero value at $273.15 \mathrm{~K}\left(0^{\circ} \mathrm{C}\right)$, the expansion is computed from $0{ }^{\circ} \mathrm{C}$ to any desired average temperature.

Case B02_10: Modify case B02_09 by introducing a positive reactivity to compensate for the feedback of moderator expansion and void. It was necessary to iterate several times, changing PARET/ANL input cards $11 \mathrm{xxx}$, in order to force the expansion case B02_10 to match the case B02_09 reactivity decrement at time 0.6400 seconds. Physically, the expansion effect of clad when it is heated up is isolated in this case.

Case B02_11: Modify case B02_09 by zeroing the thermal expansion coefficient at the input cards $11 \mathrm{xxx}$. This case involves only moderator expansion and void.

\section{Results and Discussion}

The key results are presented in

Table 3.6. It is clear that an excellent match is achieved. From the Case B02_10 data, using the input void coefficient value for DVOID of 0.3257 \$ $\%$ void, the reactivity loss of $-0.01379 \$$ is due to a void change of $0.01399 / 0.3257$ or $0.042954 \%$ void.

Using a cladding average temperature of $56.76{ }^{\circ} \mathrm{C}(329.91 \mathrm{~K})$, the core average cladding expansion is $0.23102 \%$. Scaling by DVOID yields $0.07524 \%$. For this case, the cladding surface radius (input parameter RS) is $6.35 \mathrm{E}-4 \mathrm{~m}$, and the coolant channel half-thickness (the difference of input parameters RN and RS) is $11.15 \mathrm{E}-4 \mathrm{~m}$. Therefore, the effect of cladding expansion as a percentage is reduced for the coolant channel by the ratio of the radius RS to (RN-RS), or 0.56951. Scaling $0.07524 \%$ by 0.56951 yields $0.042851 \%$ effective void. This can be compared to the previous paragraph value of $0.042954 \%$. The difference is only $0.24 \%$. 
Table 3.6. Calculation Results at $0.64 \mathrm{~s}$

\begin{tabular}{|l|c|c|c|}
\hline \multicolumn{1}{|c|}{ Parameter } & Case B02_09 & $\begin{array}{c}\text { Case B02_10 } \\
\text { (Increase reactivity } \\
\text { insertion to compensate for } \\
\text { moderator expansion and } \\
\text { void. Physically, only } \\
\text { feedback from Rod } \\
\text { expansion) }\end{array}$ & $\begin{array}{c}\text { Case B02_11 } \\
\text { (Turn off the rod } \\
\text { expansion feedback, } \\
\text { moderator expansion } \\
\text { and void remains) }\end{array}$ \\
\hline Hot channel power, MW & 0.2877 & 0.2955 & 0.2969 \\
\hline Rod expansion $\Delta$ reactivity, \$ & -0.01379 & -0.01399 & 0.00000 \\
\hline $\begin{array}{l}\text { Moderator expansion \& void, } \Delta \\
\text { reactivity, } \$\end{array}$ & -0.01383 & -0.01396 & -0.01406 \\
\hline Average cladding temperature, ${ }^{\circ} \mathrm{C}$ & 56.50 & 56.76 & 56.77 \\
\hline Average fuel meat temp., ${ }^{\circ} \mathrm{C}$ & 58.30 & 58.60 & 58.61 \\
\hline Net reactivity, $\$$ & 1.34088 & 1.3535 & 1.3515 \\
\hline Channel 1 outlet temperature, ${ }^{\circ} \mathrm{C}$ & 38.9249 & 38.9307 & 38.9373 \\
\hline
\end{tabular}

Table 3.6 also shows that the results of Cases B02_10 and B02_11 agree extremely well to each other. It means that the reactivity feedback due to the rod expansion is equivalent to that due to the moderator expansion and void as expected.

\section{Conclusion}

It is concluded that the PARET/ANL code uses the cladding surface outer dimension RS as the basis for fuel plate expansion for the plate option IGEOM=0. It is handled the same way for IGEOM=2. This is reasonable for plate-type fuels such as the aluminum-based types used in the MIT reactor, and in various SPERT-type test reactors. In those systems, the fuel meat also expands. However, the meat is typically just a few degrees hotter than is the cladding. This is because it has the fission source, and because it has a high thermal conductivity close to but less than that of pure aluminum cladding.

\subsection{Capability B3 - Reactor Trips and Delay Time}

Trips can be specified to occur when the power exceeds a specified value (over-power trip), when the reactor period is smaller than a specified value (period trip), and/or when the coolant flow falls below a specified value (low-flow trip). In the paragraphs that follow, examples for each of these types of reactor trip are described to demonstrate that PARET/ANL correctly reports when the trip occurs and when the associated scram is initiated. Cases are also included to show that the shutdown reactivity is correctly inserted when the scram occurs.

\subsubsection{Over-Power Trip}

In order to verify the over-power trip capability a transient is considered for a reactor operating at an initial power of 32 MW (Case B03_01). Reactivity feedback was disabled by using very small reactivity feedback coefficients. During the transient, the reactivity was held at its initial value of zero for one second. Then $0.5 \$$ of reactivity was inserted instantaneously at $1 \mathrm{~s}$. In this case, an over-power trip was set to occur when the power level reached 38.4 MW, and there was an assumed 10 ms delay between the time of the trip and the time of scram. PARET/ANL determines the trip time by performing a linear interpolation using the results for the last time step before reaching the overpower trip and the first time step after. Thus, if $\mathrm{P}_{\mathrm{t}}$ is the power level at which the trip is to occur, $\mathrm{P}_{1}$ is the power on the last time step before reaching the trip power, and $\mathrm{P}_{2}$ is the power on the first time 
step after the trip, the time of the trip can be estimated using the linear interpolation formula (assuming that the logarithm of the power is a constant function of time, which it is over a short time interval when the reactor is on a period)

$$
\mathrm{T}=\mathrm{t}_{1}+\left(\mathrm{t}_{2}-\mathrm{t}_{1}\right) \frac{\ln \left(\mathrm{P}_{\mathrm{t}} / \mathrm{P}_{1}\right)}{\ln \left(\mathrm{P}_{2} / \mathrm{P}_{1}\right)}
$$

where $t_{1}$ and $t_{2}$ are the times corresponding, respectively, to the powers $P_{1}$ and $P_{2}$. The time of the scram is then given by

$$
t_{s}=T+t_{d}
$$

Here $t_{d}$ is the delay time between the time of the trip and the time of the scram.

In the decay heat verification problem (Section 3.5) using the 2005 ANS standard [16] the decay heat, 10 days of irradiation prior to the start of the transient, and an energy per fission of $200 \mathrm{MeV} /$ fission, the conditions just before and just after reaching the trip power of 38.4 MW were found to be

$$
\begin{array}{lll}
\mathrm{t}_{1}=1.052 \mathrm{~s} & \text { and } & \mathrm{P}_{1}=38.3998781 \mathrm{MW} \\
\mathrm{t}_{2}=1.053 \mathrm{~s} & \text { and } & \mathrm{P}_{2}=38.5086337 \mathrm{MW}
\end{array}
$$

Inserting these values into the formula for the trip time, one finds $\mathrm{T}=1.052001 \mathrm{~s}$. Adding the delay time of $10 \mathrm{~ms}$ yields a scram time of $\mathrm{t}_{\mathrm{s}}=1.062001 \mathrm{~s}$. PARET $/$ ANL reports $\mathrm{T}=1.052001 \mathrm{~s}$ and $\mathrm{t}_{\mathrm{s}}=$ $1.062001 \mathrm{~s}$. The agreement between the calculation described above and the PARET/ANL results is exact for the 7 significant figures reported by PARET.

\subsubsection{Period Trip}

PARET/ANL does not use interpolation to determine the time for a trip on the reactor period. Instead, the time of the trip is set to the time of the time step for which the period is first found to be less than the value set for the period trip. Using the same model as used above for verification of the overpower trip, the input was modified to set a trip to occur when the period dropped below $0.221 \mathrm{~s}$ and for the scram to occur $30 \mathrm{~ms}$ later (Case B03_02). When the case was run with these input values, PARET/ANL reported that the trip occurred at $1.002000 \mathrm{~s}$ when the period had the value $0.1879772 \mathrm{~s}$. These values were reported just before the time step 1002, the first time step when the period had a value less than the input period trip value. PARET/ANL then reported a scram at $1.032000 \mathrm{~s}$ into the transient, between time steps 1032 and 1033, $30 \mathrm{~ms}$ after the trip. This is the expected behavior.

\subsubsection{Low-Flow Trip}

The model described above for verifying the over-power trip can be used also to verify the low-flow trip for the case when the coolant flow is determined by PARET/ANL input cards 10xxx with IFLOW $=1$. In this case (Case B03_03), the time of the trip is determined by interpolation directly in the input cards. To verify this, the flow on the input card 10001 was set to decrease linearly over a time period of two seconds from an initial value of $-8175 \mathrm{~kg} \mathrm{~m}^{-2} \mathrm{~s}^{-1}$ to zero. In addition, the low-flow trip was set to occur when the flow reached $60 \%$ of the initial flow with the scram to occur $10 \mathrm{~ms}$ after the trip. The time of the trip can be calculated just as described above for the over-power trip with the values for $t_{1}, t_{2}, M_{1}$, and $M_{2}$ set to the values listed in the following table. 


$$
\begin{aligned}
& \mathrm{t}_{1}=0.0 \mathrm{~s} \quad \text { and } \quad \mathrm{M}_{1}=-8175.0 \mathrm{~kg} \mathrm{~m}^{-2} \mathrm{~s}^{-1} \\
& \mathrm{t}_{2}=2.0 \mathrm{~s} \quad \text { and } \quad \mathrm{M}_{2}=0.0 \mathrm{~kg} \mathrm{~m}^{-2} \mathrm{~s}^{-1}
\end{aligned}
$$

The linear equation to solve for $\mathrm{T}$ is

$$
M(t)=M(0)+b^{*} t
$$

Slope b is $8175 . / 2$. or 4087.5

$$
M(0) \text { is } M 1=-8175.0
$$

Solving the above linear equation for $\mathrm{M}(\mathrm{t})=0.60 *(-8175)$ yields the trip time of

$$
\mathrm{T}=(8175 .-4905 .) / 4087.5=0.80000 \text {. }
$$

After adding a delay time of $10 \mathrm{~ms}$, the scram time is $t_{\mathrm{s}}=0.81000 \mathrm{~s}$. These are the values reported by PARET.

For other ways to specify the flow, PARET/ANL determines the time of the trip in subroutine flowp.f. To test the reported trip and scram times, use was made of a two-channel case (Case B03_04) in which IFLOW $=4$ and a flow coastdown is determined by PARET/ANL input cards $17 \mathrm{xxx}$. The low-flow trip was set to occur when the flow reached $85 \%$ of the initial flow. A scram was to occur $200 \mathrm{~ms}$ after the trip. A low-flow trip at $4.0939 \mathrm{~s}$ and a scram at $4.293941 \mathrm{~s}$ were reported by PARET. This indicates that the scram was occurring at the correct time relative to the reported time of the trip. Edits for channel 1 and channel 2 provide the value of the flow in each channel to five significant figures. Flow results are the same for each channel on the time step just before the reported low-flow trip and the time step just after the trip. The code interpolates using flow values on these time steps in the same manner as described above for the over-power trip. Results used for this interpolation, to the number of significant figures reported by PARET, are listed in the following table.

$$
\begin{array}{lll}
\mathrm{t}_{1}=4.09300 \mathrm{~s} & \text { and } & \ln \left(\mathrm{P}_{1}\right)=-2321.0 \mathrm{~kg} \mathrm{~m}^{-2} \mathrm{~s}^{-1} \\
\mathrm{t}_{2}=4.09400 \mathrm{~s} & \text { and } & \ln \left(\mathrm{P}_{2}\right)=-2320.9 \mathrm{~kg} \mathrm{~m}^{-2} \mathrm{~s}^{-1}
\end{array}
$$

The initial flow is $-2730.5 \mathrm{~kg} \mathrm{~m}^{-2} \mathrm{~s}^{-1}$ and the value for the trip flow is $\ln \left(\mathrm{P}_{\mathrm{t}}\right)=0.85 \times(-2730.5)=$ $-2320.925 \mathrm{~kg} \mathrm{~m}^{-2} \mathrm{~s}^{-1}$. Inserting these values into the interpolation formula, one finds $\mathrm{T}=4.09375 \mathrm{~s}$ and $t_{s}=4.29375 \mathrm{~s}$. Given the number of significant figures available in the foregoing table, these results are in good agreement with the values reported in the PARET/ANL output.

\subsection{Capability B4 - Control Rod Reactivity}

PARET/ANL uses input cards 18xxx to represent the control rod reactivity worth vs. insertion. It is piecewise-linearly interpolated. The use of this input data is controlled by variable RDRATE supplied on input card 1113. Given input cards 18xxx, and a reactor model that begins a transient event such as a step insertion, the power will exponentially increase until a trip occurs. After the reactor trip is initiated by the reactor control system, there is a reactor scram after a prescribed delay. The control rods are inserted and the shutdown reactivity insertion proceeds. It must be shown that the reactivity expected at full insertion occurs at the time expected according to the time of trip plus the time since trip plus the time for full insertion. 
To verify this capability, a new test case B04_01 is created by modifying the test case B03_01 mentioned in Section 3.3. All reactivity feedbacks are removed and the step reactivity insertion is set at $0.5 \$$. The input cards $18 \mathrm{xxx}$ describe the control rods which insert $-15.04 \$$ within $0.5 \mathrm{~s}$. The PARET/ANL calculation results (Figure 3.4) show that the power trip and reactor scram occur at 1.052 and $1.062 \mathrm{~s}$, respectively. The total reactivity reported at $1.062+0.5=1.562 \mathrm{~s}$ is $-14.04 \$$ which exactly equals the sum of step reactivity insertion $(0.5 \$)$ and reactivity introduced by the control rods $(-15.04 \$)$ as expected.

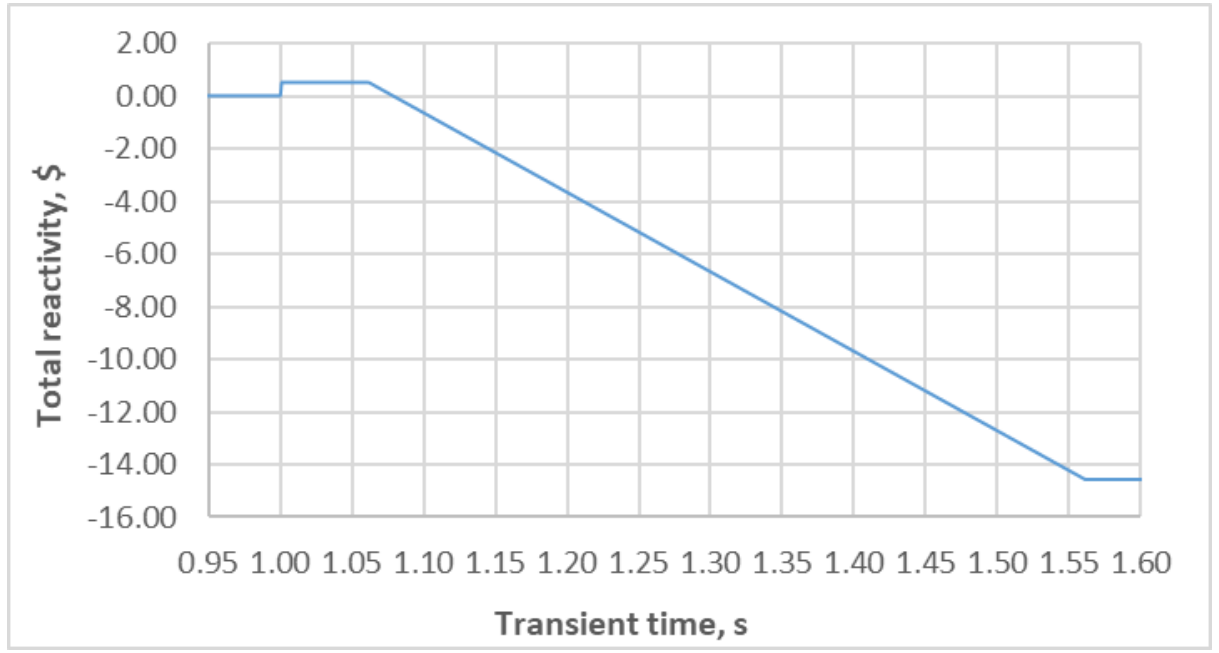

Figure 3.4. Total Reactivity Calculated by PARET/ANL

\subsection{Capability B5 - Decay Heat}

The PARET/ANL computer code contains an approximate treatment of decay heat resulting from the irradiation of the fuel both prior to the start of a transient and during the transient. For the decay heat calculation, PARET/ANL uses a constant fission power, specified by the user, for the entire time period from the beginning of the irradiation prior to the start of a transient up until the time of a scram that results from a reactor trip during the transient. In addition, a time delay between the time of the trip and the time of the scram can be specified by the user. At the beginning of the transient the fission power calculated by PARET/ANL is initialized to the total reactor power minus whatever decay heat power has built up as a result of the prior irradiation. Following the scram, there is no further irradiation of the fuel for the purpose of decay heat production even though the actual fission power may be significant for some period of time following the scram. At the user's choice, the code will use the ANS 2005 Standard [16] (the recommended default option) or the ANS 1973 Standard [17] (a legacy option) for the calculation of decay heat. Whichever standard is chosen, the code assumes that the fuel contains ${ }^{235} \mathrm{U}$ as primary fissile isotope. However, the user can change the $\mathrm{MeV} /$ fission input to match that of some other mixture of fissile isotopes.

To verify the PARET/ANL model, the model was independently recreated in an Excel spreadsheet using the macro capabilities provided by Excel. Mathematically, the model can be described as follows. Let $f(t)$ be the decay power at time $t$ resulting from a single fission at time zero. Then if $t \geq 0$, the decay heat at time $t$ due to a constant fission rate of 1 fission/second for all times prior to time zero can be expressed as 


$$
F(t)=\int_{-\infty}^{0} d t^{\prime} f\left(t-t^{\prime}\right)
$$

If a reactor is operated at a fission power $\mathrm{P}_{0}$ for a time $\mathrm{T}$ prior to the start of a transient and continues to operate at the same power level for a time $t$ after the transient starts, this function can be used to evaluate the decay heat as

$$
P_{d}(t)=\frac{P_{0}}{Q}[F(0)-F(t+T)]
$$

when the scram has not occurred. If a scram occurs at time $t_{S}$ after the start of the transient the decay heat at time $t$ after the start of the transient can be evaluated as

$$
P_{d}(t)=\frac{P_{0}}{Q}\left[F\left(t-t_{S}\right)-F(t+T)\right]
$$

In these expressions, $\mathrm{Q}$ is the energy released per fission. In PARET/ANL, $\mathrm{Q}=200 \mathrm{MeV} /$ fission is the default value (but is an input). When the 2005 ANS Standard is used, the function $\mathrm{f}(\mathrm{t})$ is expressed as a sum of 23 exponentials and the expressions involving the function $\mathrm{F}(\mathrm{t})$ can be expressed as the sum of 23 terms using the parameters from the 23 exponentials. When the 1973 ANS Standard is used, the decay power is evaluated by linear interpolation in a table of the logarithm of $F(t)$ as a function of the logarithm of $\mathrm{t}$.

To verify the PARET/ANL calculation, the code was run for two irradiation times, 3 days and 10 days, prior to the start of the transient. For purposes of the decay heat calculation, the fission power was assumed to be $32 \mathrm{MW}$. During the transient, the initial total power of the reactor was assumed to be $32 \mathrm{MW}$ and reactivity feedback was disabled by using very small reactivity feedback coefficients. At one second into the transient, $0.5 \$$ of reactivity was inserted over a time period of 0.00001 seconds. A trip was set to occur when the power reached a user determined trip-power. To estimate the time when the trip occurred, PARET/ANL interpolates a time between the time of the last time step before the trip-power is reached and the time of the first time step when the power exceeds the trip-power (as described in Section 3.3.1). Different aspects of the decay heat calculation are verified by comparing between the PARET/ANL and hand calculations of the test cases presented in Table 3.7.

Table 3.7. Test Cases Used for Verification of Decay Heat Calculation

\begin{tabular}{|c|c|c|c|c|c|}
\hline Test Case & $\begin{array}{c}\text { ANS } \\
\text { Standard }\end{array}$ & $\begin{array}{c}\text { \# Day Prior } \\
\text { Irradiation }\end{array}$ & $\begin{array}{c}\text { Trip Power, } \\
\text { MW }\end{array}$ & $\begin{array}{c}\text { Delay Time, } \\
\text { ms }\end{array}$ & MeV/fission \\
\hline B05_01 & 2005 & 3 & 32.001 & 0.0 & 200 \\
\hline B05_02 & 2005 & 10 & 32.001 & 0.0 & 200 \\
\hline B05_03 & 1973 & 3 & 32.001 & 0.0 & 200 \\
\hline B05_04 & 1973 & 10 & 32.001 & 0.0 & 200 \\
\hline B05_05 & 2005 & 10 & 38.400 & 10.0 & 200 \\
\hline B05_06 & 1973 & 10 & 38.400 & 10.0 & 200 \\
\hline B05_07 & 2005 & 3 & 32.001 & 0.0 & 210 \\
\hline B05_08 & 1973 & 3 & 32.001 & 0.0 & 210 \\
\hline
\end{tabular}

An initial set of calculations for 3-day prior irradiation (Case B05_01) and for 10-day prior irradiation (Case B05_02) were run with the trip-power set to $32.001 \mathrm{MW}$ and a time delay between the 
estimated trip time and the scram time of zero. This choice of trip-power and time delay had the consequence that the calculated decay heat power on the first time step after the power reached 32.001 MW retained the value it would have had if the trip and corresponding scram had not occurred. At all the following time steps the decay heat power is calculated as if the irradiation of the fuel stopped at the estimated scram time. The PARET/ANL results for this case are compared with Excel calculations in Table 3.8 for the case when the 2005 ANS Standard is selected.

Table 3.8. Comparison of Calculations Using 2005 ANS Standard

\begin{tabular}{|c|c|c|c|c|}
\hline \multirow{2}{*}{ Times, s } & \multicolumn{4}{|c|}{ Decay Heat Power, MW } \\
\cline { 2 - 5 } & \multicolumn{2}{|c|}{ 3 Day Prior Irradiation } & 10 Day Prior Irradiation \\
\cline { 2 - 5 } & PARET & Hand & PARET & Hand \\
\hline 0.00100 & 2.028175 & 2.028175 & 2.059238 & 2.059238 \\
\hline 1.00000 & 2.028175 & 2.028175 & 2.059238 & 2.059238 \\
\hline 1.00100 & 2.028175 & 2.027936 & 2.059238 & 2.059016 \\
\hline 1.00200 & 2.027712 & 2.027712 & 2.058792 & 2.058792 \\
\hline 40.00000 & 1.076172 & 1.076172 & 1.107249 & 1.107249 \\
\hline
\end{tabular}

For both the 3-day and 10-day prior irradiations the estimated scram time was 1.000009 seconds. If the delay time had been set to a value larger than the size of the time step used in the PARET/ANL calculation, the decay power calculated on the first time step after the scram would have agreed with the Excel calculation. As can be seen in Table 3.8, for all times except the time step immediately following the scram, the PARET/ANL and Excel calculations are identical for the number of significant figures reported by the PARET/ANL code.

Table 3.9 shows the results from a repetition of the foregoing calculations using the 1973 ANS Standard instead of the 2005 ANS Standard. For these cases for 3-day prior irradiation (Case B05_03) and for 10-day prior irradiation (Case B05_04), the estimated scram time for the 3-day and 10-day prior irradiations is 1.000011 seconds. The small difference compared to the case of 2005 ANS Standard is due to the numerical solution which interpolates the trip time between the time steps has negligible effect on the results. The fact that the PARET/ANL and Excel calculations agree for the first time step following the scram time is caused by the fact that the tabulated values for the function $F(t)$ in the 1973 Standard do not include a value for $\mathrm{t}=0$. The function $\mathrm{F}(\mathrm{t}+\mathrm{T})$ changes very slowly during the transient. The function $F\left(t-t_{S}\right)$ is assigned the value $F(0.1)$ until $t>t_{S}+0.1$. As can be seen in the table, the PARET/ANL and Excel calculations agree for all of the significant figures reported by PARET/ANL.

Table 3.9. Comparison of Calculations Using 1973 ANS Standard

\begin{tabular}{|c|c|c|c|c|}
\hline \multirow{2}{*}{ Times, s } & \multicolumn{4}{|c|}{ Decay Heat Power, MW } \\
\cline { 2 - 5 } & 3 Day Prior Irradiation & 10 Day Prior Irradiation \\
\cline { 2 - 5 } & PARET & Hand & PARET & Hand \\
\hline 0.00100 & 2.039682 & 2.039682 & 2.071445 & 2.071445 \\
\hline 1.00000 & 2.039682 & 2.039682 & 2.071445 & 2.071445 \\
\hline 1.00100 & 2.039682 & 2.039682 & 2.071445 & 2.071445 \\
\hline 1.00200 & 2.039682 & 2.039682 & 2.071445 & 2.071445 \\
\hline 40.00000 & 1.152817 & 1.152817 & 1.184577 & 1.184577 \\
\hline
\end{tabular}

Table 3.10 shows the results of two additional calculations using the 2005 ANS Standard (Case B05_05) and using the 1973 ANS Standard (Case B05_06), carried out for a 10-day prior irradiation 
and the more realistic values of $38.4 \mathrm{MW}$ for the trip-power and a delay time of 10 milliseconds between the trip time and the scram time. Scram times for these calculations were 1.062001 seconds and 1.062025 seconds, respectively, for the 2005 and 1973 ANS Standards. Because of the 10 millisecond delay between the trip time and the scram time, several time steps occurred during the delay time period. The PARET/ANL and the Excel calculations agree at all times for the number of significant figures reported by PARET/ANL.

Table 3.10. Comparison for a Trip Power of 38.4 MW and Delay Time of $10 \mathrm{~ms}$

\begin{tabular}{|c|c|c|c|c|}
\hline \multirow{2}{*}{ Times, s } & \multicolumn{4}{|c|}{ Decay Heat Power, MW } \\
\cline { 2 - 5 } & \multicolumn{2}{|c|}{ 2005 ANS Standard } & 1973 ANS Standard \\
\cline { 2 - 5 } & PARET & Hand & PARET & Hand \\
\hline 0.00100 & 2.059238 & 2.059238 & 2.071445 & 2.071445 \\
\hline 1.06200 & 2.059238 & 2.059238 & 2.071445 & 2.071445 \\
\hline 1.06300 & 2.059014 & 2.059014 & 2.071445 & 2.071445 \\
\hline 40.00000 & 1.107610 & 1.107610 & 1.184951 & 1.184951 \\
\hline
\end{tabular}

As noted earlier, the default value for the energy release per fission is $200 \mathrm{MeV} /$ fission. However, the input card 1700 allows the user to assign a different value to $Q$. To verify that the user assigned value is correctly implemented, the input card 1700 was used to assign the value $Q=210 \mathrm{MeV} /$ fission for the cases listed in Table 3.8 and Table 3.9 for prior irradiation of 3 days. PARET/ANL calculations using the 2005 ANS Standard (Case B05_07) and using the 1973 ANS Standard (Case B05_08) with this new value for $Q$ are compared with corresponding Excel calculation in Table 3.11.

Table 3.11. Comparison for a Prior Irradiation of 3 Days with $Q=210 \mathrm{MeV} /$ fission

\begin{tabular}{|c|c|c|c|c|}
\hline \multirow{2}{*}{ Times, s } & \multicolumn{4}{|c|}{ Decay Heat Power, MW } \\
\cline { 2 - 5 } & \multicolumn{2}{|c|}{ 2005 ANS Standard } & \multicolumn{1}{|c|}{ 1973 ANS Standard } \\
\cline { 2 - 5 } & PARET & Hand & PARET & Hand \\
\hline 0.00100 & 1.931578 & 1.931578 & 1.942555 & 1.942555 \\
\hline 1.00000 & 1.931579 & 1.931579 & 1.942555 & 1.942555 \\
\hline 1.00100 & 1.931579 & 1.931367 & 1.942555 & 1.942555 \\
\hline 1.00200 & 1.931154 & 1.931154 & 1.942555 & 1.942555 \\
\hline 40.00000 & 1.024925 & 1.024925 & 1.097921 & 1.097921 \\
\hline
\end{tabular}

As in the previous cases, the PARET/ANL and Excel calculations agree for all of the significant figures reported by PARET. In addition, the decay heat values listed in Table 3.8 and Table 3.9 are scaled by a factor of 200/210 in Table 3.11, as expected.

\subsection{Capability B6 - Power-Driven Mode}

The PARET/ANL option which allows the user to specify the reactor power as a function of time can be verified by first running a problem in which the imposed reactivity as a function of time is specified. The input cards $9 \mathrm{xxx}$ can then be used to specify the power that results from the reactivity transient. Thermal-hydraulic results that are calculated during a transient driven by the power as a function of time can then be compared with the corresponding results obtained in the original reactivity driven transient. The specification using input cards 9xxx is limited to no more than 100 power/time pairs. Because linear interpolation is used in PARET/ANL, the accuracy obtained in the comparisons will be somewhat limited. Nevertheless the results to be described in the following 
paragraphs, using three sets of time points for input cards 9xxx, demonstrate that very good agreement can be obtained between the power and reactivity driven transients.

Test case B01_29 mentioned in Section 3.1 provides a suitable test problem for verification of the PARET/ANL power as a function of time option. For the first set of time points (Case B06_01), PARET/ANL input cards $9 \mathrm{xxx}$ included 51 time points starting with time $\mathrm{t}=0$ and ending at $2 \mathrm{~s}$ separated by time intervals of $0.04 \mathrm{~s}$. Figure 3.5 shows the power interpolated from input cards $9 \mathrm{xxx}$ as well as the power from the reactivity-driven case. As shown in Figure 3.5, the interpolated power falls below the power of the reactivity-driven case from slightly after 1 second, especially near the time of peak power and near $1.5 \mathrm{~s}$. The power at the time $1.5 \mathrm{~s}$ is not included in the Table 9 input (the comparison would have been more accurate if it was included).

The second set of time points (Case B06_02) includes 100 time points in Table 9 from time=0 to time $=2 \mathrm{~s}$. All time points are separated by time intervals of length $(2 / 99) \mathrm{s}$ except for one time point adjusted to match the time of the peak power shown in the reactivity-driven case, $1.0412 \mathrm{~s}$. The power interpolated from input cards 9xxx is compared with the power from of reactivity-driven case in Figure 3.6. It can be seen that the agreement between these data is better than in the case with 51 time points. For the third set of time points (Case B06_03), 25 equal-length time intervals were placed between 0 and $1 \mathrm{~s}, 50$ time intervals between $1 \mathrm{~s}$ and $1.5 \mathrm{~s}, 5$ time intervals between $1.5 \mathrm{~s}$ and $1.55 \mathrm{~s}$, and 9 time intervals between $1.55 \mathrm{~s}$ and $2 \mathrm{~s}$. This gives a total of 90 time points in the 9xxx input cards.

Some key results from the three power vs. time cases are compared with the original reactivity vs. time case in Table 3.12. While the reactor model used for this verification exercise includes four channels, the comparisons in Table 3.12 include only the first two channels. For the most part, the results from the 100-point and 90-point of input cards 9xxx are very similar. The temperatures at $1.5 \mathrm{~s}$ for the 90 -point results agree more closely with the reactivity-driven case because more points were included in the time interval between 1 and $1.5 \mathrm{~s}$. Also, the powers at $1 \mathrm{~s}$ and $1.5 \mathrm{~s}$ are included in the input cards $9 \mathrm{xxx}$. The time interval from $1 \mathrm{~s}$ to $1.5 \mathrm{~s}$ includes the highest power and contributes the largest fraction of the energy release. 


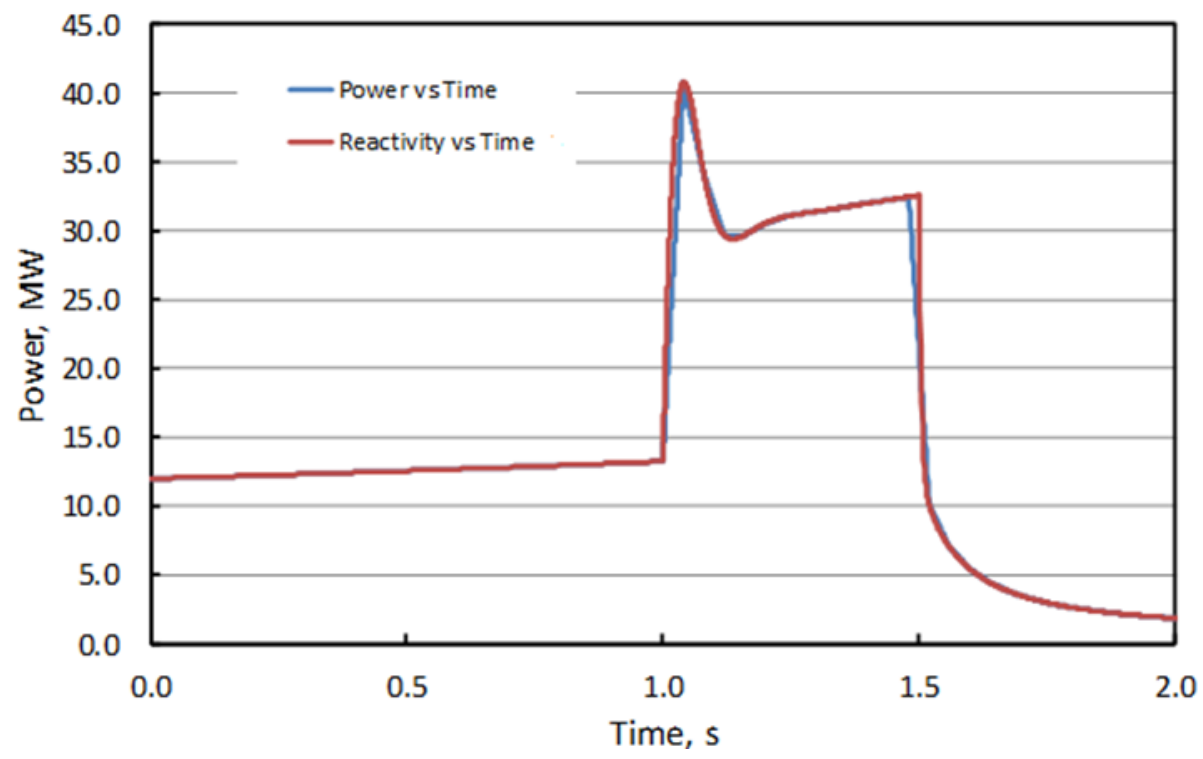

Figure 3.5. Comparison of Power Table of 51 Time Points with Reactivity Driven Case.

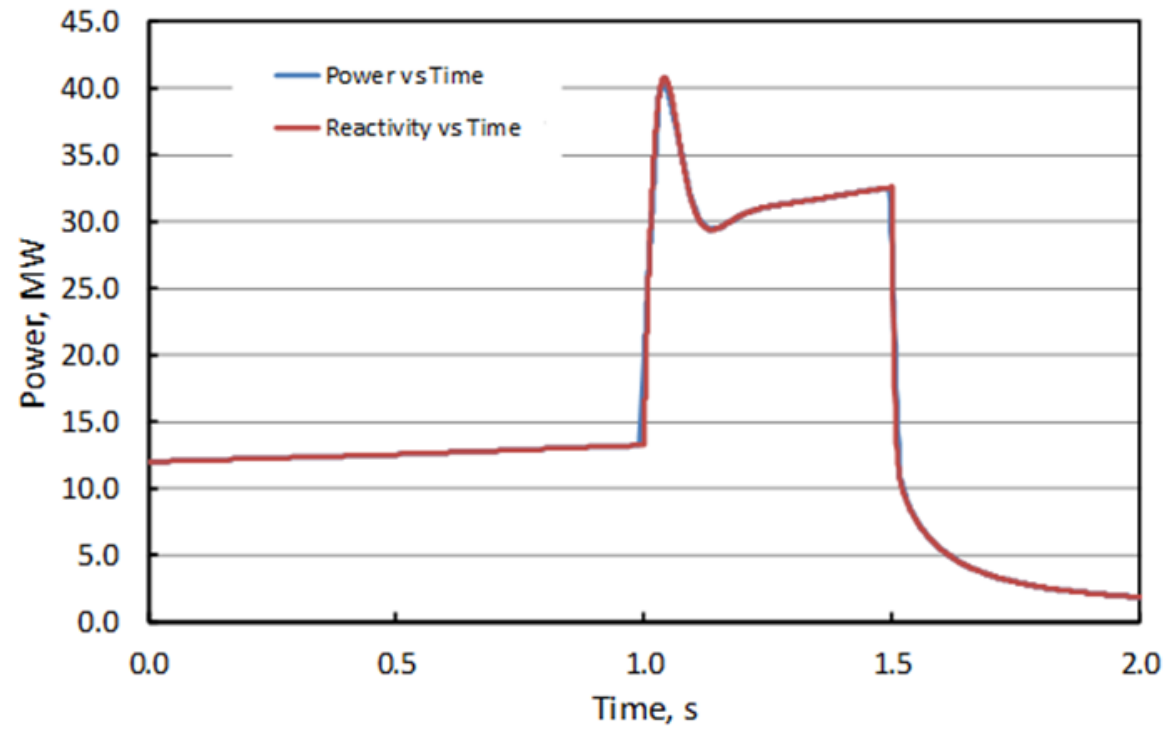

Figure 3.6. Comparison of Power Table of 100 Time Points with Reactivity Driven Case. 
Table 3.12. Comparison of Key Results

\begin{tabular}{|c|c|c|c|c|c|c|c|c|c|}
\hline \multirow[b]{2}{*}{ Chanel } & \multirow[b]{2}{*}{ Parameter } & \multirow[b]{2}{*}{ Time } & \multirow{2}{*}{$\begin{array}{c}\text { Reactivity- } \\
\text { Driven } \\
\text { Mode }\end{array}$} & \multicolumn{6}{|c|}{ Power-Driven Mode } \\
\hline & & & & \begin{tabular}{|c|}
51 \\
Points \\
\end{tabular} & \begin{tabular}{|c|} 
Diff., \\
$\%$
\end{tabular} & \begin{tabular}{|c|}
100 \\
Points
\end{tabular} & $\begin{array}{c}\text { Diff., } \\
\%\end{array}$ & \begin{tabular}{|c|}
90 \\
Points
\end{tabular} & $\begin{array}{c}\text { Diff., } \\
\%\end{array}$ \\
\hline \multirow{5}{*}{$1 \& 2$} & \multirow{5}{*}{ Energy, MJ } & $1 \mathrm{~s}$, Prior to Reactivity Step & 12.5876 & 12.5743 & -0.106 & 12.6053 & 0.141 & 12.5743 & -0.106 \\
\hline & & Time of Peak Power, $\mathrm{s}$ & 1.0413 & 1.0400 & -0.125 & 1.0413 & 0.000 & 1.0400 & -0.125 \\
\hline & & At Time of Peak Power & 13.9402 & 13.6679 & -1.953 & 13.9736 & 0.240 & 13.8692 & -0.509 \\
\hline & & $1.5 \mathrm{~s}$, Prior to Reactivity Step & 28.5454 & 28.2177 & -1.148 & 28.5613 & 0.056 & 28.5311 & -0.050 \\
\hline & & $2.0 \mathrm{~s}$ & 30.5975 & 30.2946 & -0.990 & 30.6543 & 0.186 & 30.6313 & 0.110 \\
\hline \multirow{20}{*}{1} & \multirow{5}{*}{$\begin{array}{l}\text { Fuel } \\
\text { Temp., }{ }^{\circ} \mathrm{C}\end{array}$} & $1 \mathrm{~s}$, Prior to Reactivity Step & 113.38 & 113.38 & 0.000 & 117.15 & 3.325 & 113.38 & 0.000 \\
\hline & & Time of Peak, $s$ & 1.5000 & 1.4800 & -1.333 & 1.4950 & -0.333 & 1.5000 & 0.000 \\
\hline & & Peak & 190.71 & 190.25 & -0.241 & 190.6 & -0.058 & 190.71 & 0.000 \\
\hline & & $1.5 \mathrm{~s}$, Prior to Reactivity Step & 190.71 & 181.27 & -4.950 & 189.03 & -0.881 & 190.71 & 0.000 \\
\hline & & $2.0 \mathrm{~s}$ & 64.059 & 64.067 & 0.012 & 64.062 & 0.005 & 64.075 & 0.025 \\
\hline & \multirow{5}{*}{$\begin{array}{l}\text { Cladding } \\
\text { Temp., }{ }^{\circ} \mathrm{C}\end{array}$} & $1 \mathrm{~s}$, Prior to Reactivity Step & 93.025 & 93.024 & -0.001 & 93.942 & 0.986 & 93.024 & -0.001 \\
\hline & & Time of Peak, $s$ & 1.5011 & 1.4820 & -1.270 & 1.4950 & -0.404 & 1.501 & -0.005 \\
\hline & & Peak & 143.2 & 142.92 & -0.196 & 143.13 & -0.049 & 143.21 & 0.007 \\
\hline & & $1.5 \mathrm{~s}$, Prior to Reactivity Step & 143.2 & 139.74 & -2.416 & 142.94 & -0.182 & 143.2 & 0.000 \\
\hline & & $2.0 \mathrm{~s}$ & 60.908 & 60.914 & 0.010 & 60.911 & 0.005 & 60.922 & 0.023 \\
\hline & \multirow{5}{*}{$\begin{array}{l}\text { Coolant } \\
\text { Temp., }{ }^{\circ} \mathrm{C}\end{array}$} & $1 \mathrm{~s}$, Prior to & 735 & 68.733 & -0.003 & 68.714 & -0.031 & 68.733 & -0.003 \\
\hline & & Time of & 1.5051 & 1.491 & -0.935 & 1.504 & -0.071 & 1.508 & 0.195 \\
\hline & & Peak & 89.283 & 89.19 & -0.104 & 89.282 & -0.001 & 89.314 & 0.035 \\
\hline & & $1.5 \mathrm{~s}$, Prior to Reactivity Step & 89.269 & 89.135 & -0.150 & 89.267 & -0.002 & 89.269 & 0.000 \\
\hline & & $2.0 \mathrm{~s}$ & 56.841 & 56.843 & 0.004 & 56.842 & 0.002 & 56.846 & 0.009 \\
\hline & \multirow{5}{*}{$\begin{array}{l}\text { Critical } \\
\text { Heat } \\
\text { Flux Ratio }\end{array}$} & $1 \mathrm{~s}$, Prior to Reactivity Step & 8.436 & 8.433 & -0.036 & 8.175 & -3.094 & 8.433 & -0.036 \\
\hline & & Time of Minimum, $\mathrm{s}$ & 1.5000 & 1.4800 & -1.333 & 1.4950 & -0.333 & 1.5 & 0.000 \\
\hline & & Minimum & 3.279 & 3.292 & 0.396 & 3.282 & 0.091 & 3.279 & 0.000 \\
\hline & & $1.5 \mathrm{~s}$, Prior to & 79 & 455 & 5.367 & 3.292 & 0.396 & 3.279 & 0.000 \\
\hline & & $2.0 \mathrm{~s}$ & 35 & 54.8 & -0.091 & 54.82 & -0.055 & 54.76 & -0.164 \\
\hline & \multirow{5}{*}{$\begin{array}{l}\text { Fuel } \\
\text { Temp., }{ }^{\circ} \mathrm{C}\end{array}$} & $1 \mathrm{~s}$, Prior to Reactivity Step & 156.43 & 156.43 & 0.000 & 164.13 & 4.922 & 156.43 & 0.000 \\
\hline & & Time of Peak, $\mathrm{s}$ & 1.0555 & 1.0614 & 0.559 & 1.0538 & -0.161 & 1.0555 & 0.000 \\
\hline & & Peak & 255.45 & 251.1 & -1.703 & 254.28 & -0.458 & 255.13 & -0.125 \\
\hline & & $1.5 \mathrm{~s}$, Prior to Reactivity Step & 241.99 & 225.69 & -6.736 & 238.39 & -1.488 & 241.99 & 0.000 \\
\hline & & $2.0 \mathrm{~s}$ & 71.326 & 71.34 & 0.020 & 71.33 & 0.006 & 71.349 & 0.032 \\
\hline & \multirow{5}{*}{$\begin{array}{l}\text { Cladding } \\
\text { Temp., }{ }^{\circ} \mathrm{C}\end{array}$} & $1 \mathrm{~s}$, Prior to Reactivity Step & 133.53 & 133.53 & 0.000 & 135.88 & 1.760 & 133.53 & 0.000 \\
\hline & & Time of Peak, $\mathrm{s}$ & 1.0582 & 1.0653 & 0.671 & 1.0578 & -0.038 & 1.0591 & 0.085 \\
\hline & & Peak & 193.05 & 191.98 & -0.554 & 192.78 & -0.140 & 192.98 & -0.036 \\
\hline & & $1.5 \mathrm{~s}$, Prior to Reactivity Step & 189.67 & 185.52 & -2.188 & 189.23 & -0.232 & 189.67 & 0.000 \\
\hline & & $2.0 \mathrm{~s}$ & 67.698 & 67.711 & 0.019 & 67.702 & 0.006 & 67.719 & 0.031 \\
\hline & \multirow{5}{*}{$\begin{array}{l}\text { Coolant } \\
\text { Temp., }{ }^{\circ} \mathrm{C}\end{array}$} & $1 \mathrm{~s}$, Prior to Reactivity Step & 81.684 & 81.682 & -0.002 & 81.644 & -0.049 & 81.682 & -0.002 \\
\hline & & Time of Peak, $s$ & 1.1013 & 1.1120 & 0.972 & 1.1020 & 0.064 & 1.1019 & 0.054 \\
\hline & & Peak & 123.61 & 120.93 & -2.168 & 123.38 & -0.186 & 123.43 & -0.146 \\
\hline & & $1.5 \mathrm{~s}$, Prior to $\mathrm{R}$ & 120.97 & 120.04 & -0.769 & 120.95 & -0.017 & 120.97 & 0.000 \\
\hline & & $2.0 \mathrm{~s}$ & 58.925 & 58.93 & 0.008 & 58.927 & 0.003 & 58.934 & 0.015 \\
\hline & \multirow{5}{*}{$\begin{array}{l}\text { Critical } \\
\text { Heat } \\
\text { Flux Ratio }\end{array}$} & $1 \mathrm{~s}$, Prior to Reactivity Step & 3.639 & 3.638 & -0.027 & 3.509 & -3.572 & 3.638 & -0.027 \\
\hline & & Time of Minimum, $s$ & 1.0598 & 1.0663 & 0.613 & 1.0589 & -0.085 & 1.0604 & 0.057 \\
\hline & & Minimum & 1.1260 & 1.202 & 6.750 & 1.1450 & 1.687 & 1.1310 & 0.444 \\
\hline & & $1.5 \mathrm{~s}$, Prior to Reactivity Step & 1.349 & 1.638 & 21.423 & 1.38 & 2.298 & 1.349 & 0.000 \\
\hline & & $2.0 \mathrm{~s}$ & 24.63 & 24.61 & -0.081 & 24.63 & 0.000 & 24.6 & -0.122 \\
\hline
\end{tabular}

The energy release as a function of time obtained using the 90-point of input cards 9xxx is compared with the corresponding energy release from the PARET/ANL calculation with the reactivity specified as a function of time in Figure 3.7. As can be seen, the two results are indistinguishable from one 
another. In Figure 3.8, Figure 3.9, and Figure 3.10, the corresponding peak fuel temperatures, peak coolant temperatures, and minimum critical heat flux ratios are compared for the power vs. time case (also using the 90-point of input cards $9 \mathrm{xxx}$ ) and the reactivity vs. time case. The comparisons are for channel 1, the channel representing the average behavior in the core. Not shown are similar plots for channels 2, 3, and 4 that exhibit equally good agreement. Channels 2,3 , and 4 are higher powered channels. Nucleate boiling occurs in each of the channels, starting near the time of peak power and ending a short time after $1.5 \mathrm{~s}$. Agreement between the power vs. time calculation and the reactivity vs. time calculation is as good for these channels as for channel 1 with exception that at most of the input cards 9xxx time points where nucleate boiling is in progress in the power vs. time case, the minimum critical heat flux ratio exhibits an oscillation. Between the time points, the critical heat flux ratio plots agree very closely with no oscillations in either of the calculations.

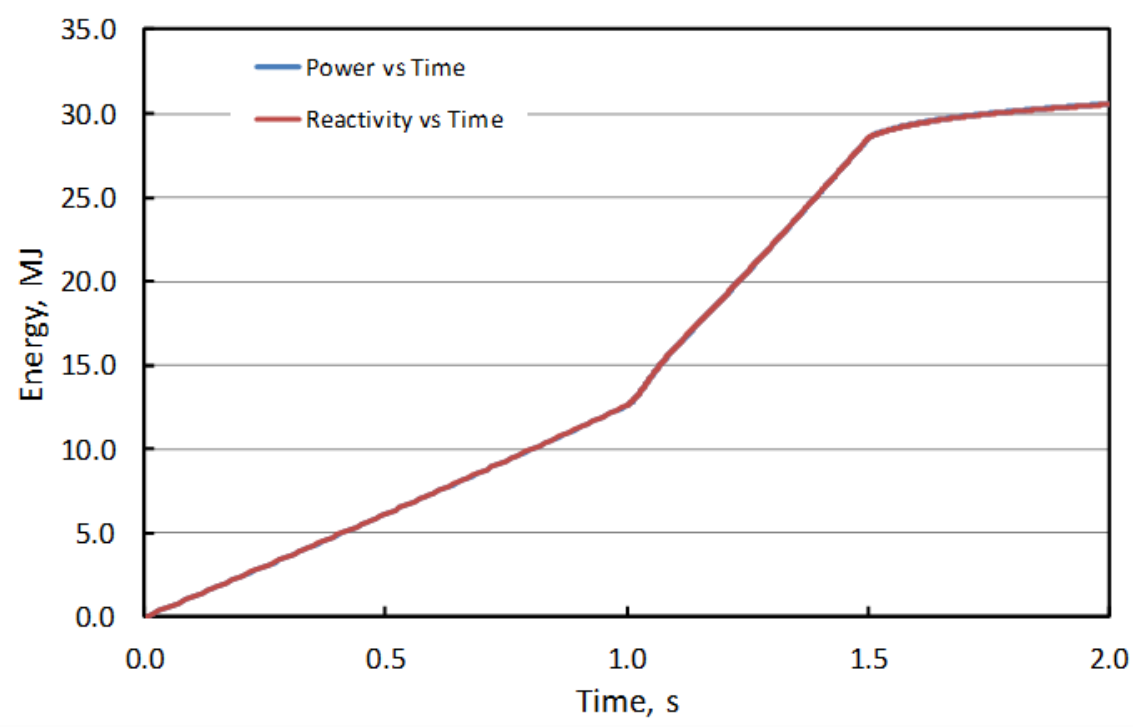

Figure 3.7. Energy Release.

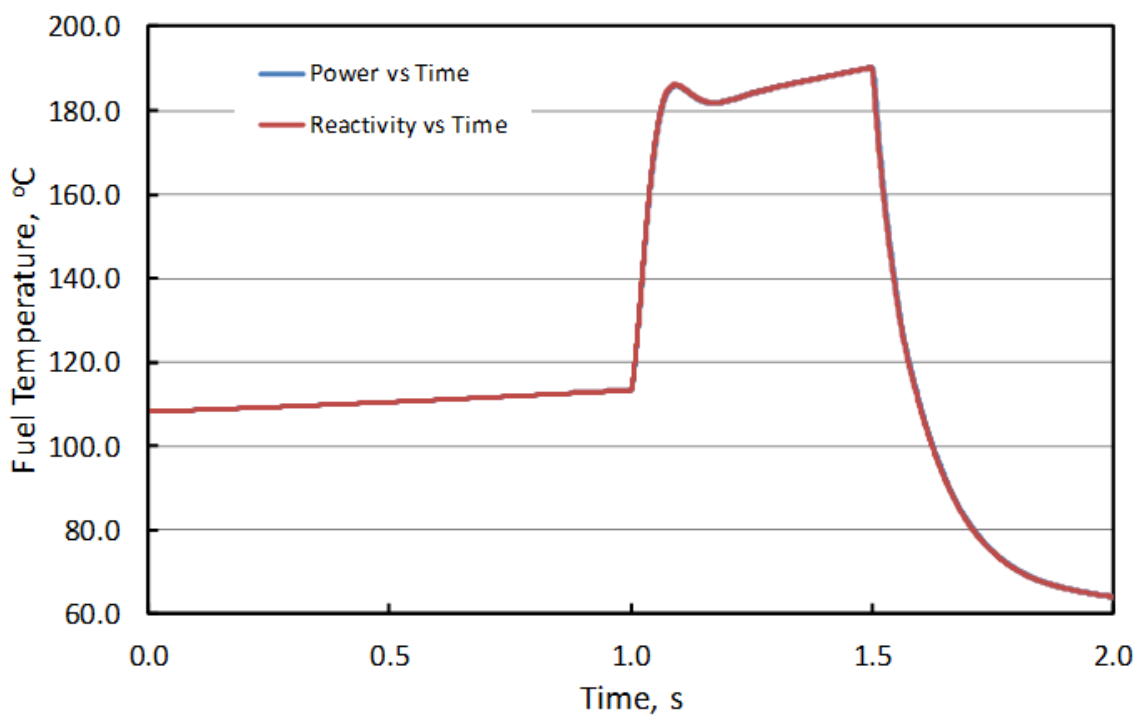

Figure 3.8. Peak Fuel Temperature in Channel 1 


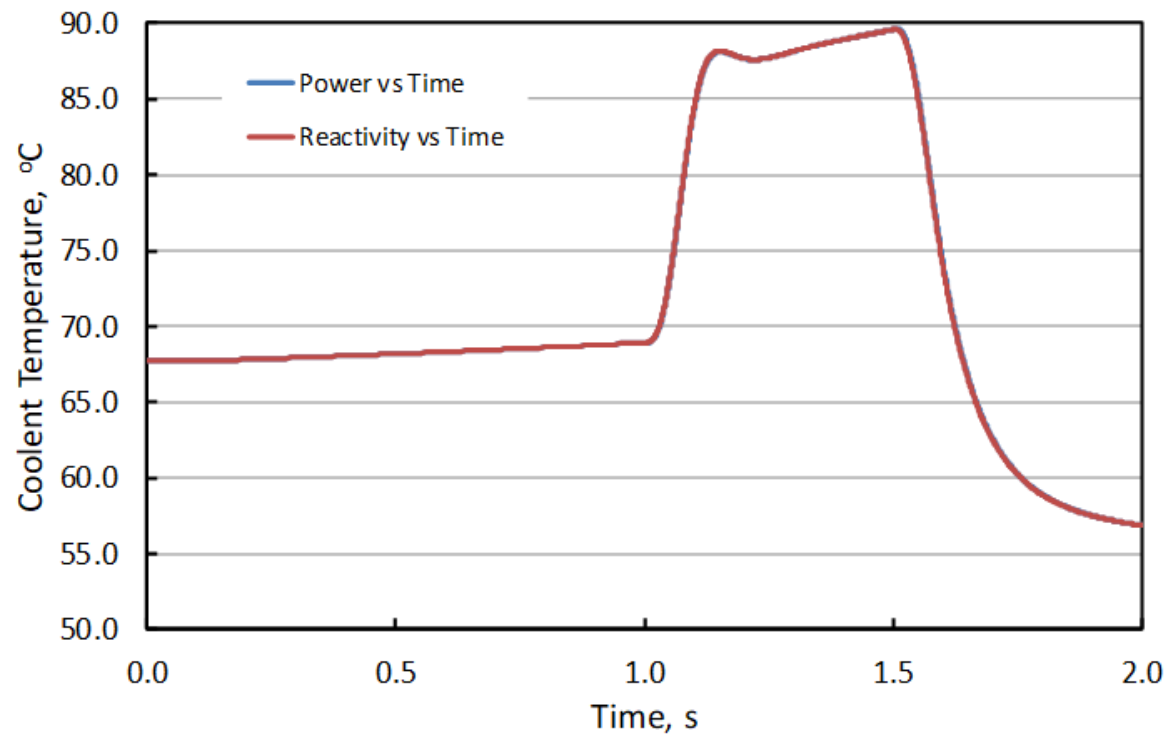

Figure 3.9. Peak Coolant Temperature in Channel 1.

Figure 3.11, Figure 3.12, and Figure 3.13 show comparisons of the axial distributions, respectively, of the coolant temperature, cladding surface temperature, and maximum fuel temperature from the power vs. time calculation with the corresponding results from the reactivity vs. time calculation. The comparisons are made at $1.06 \mathrm{~s}$, a time just after the time of peak power. In the power vs. time option, input cards $9 \times x x$ contained 90 time points. The results shown indicate very good agreement between the two calculations. The maximum percent differences between the two calculations are $0.61 \%$, $0.34 \%$, and $0.32 \%$, respectively for the coolant, cladding, and fuel temperatures. It should be noted that for the power vs. time calculation, PARET/ANL reports nucleate boiling in axial nodes 1 through 14. It should also be noted that for the reactivity vs. time calculation, PARET/ANL also reports nucleate boiling in axial nodes 1 through 14. Similar results were observed for channels 3 and 4 .

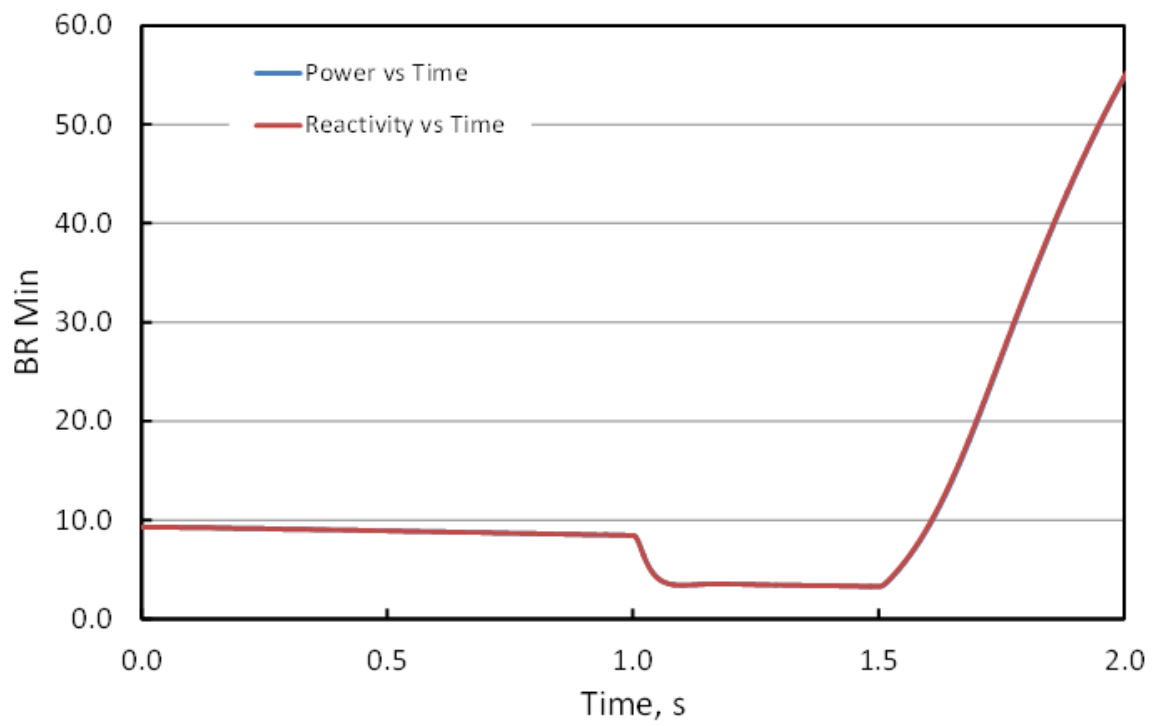

Figure 3.10. Minimum CHF Ratio in Channel 1 


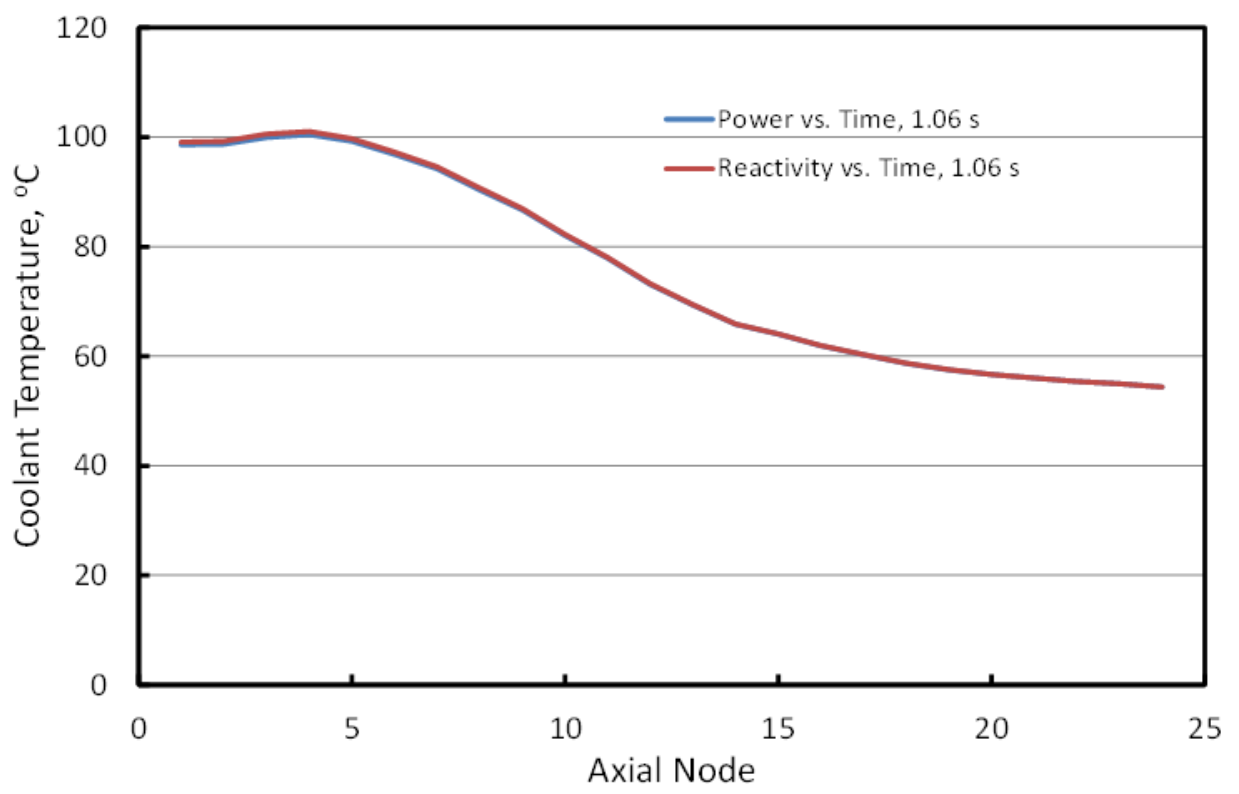

Figure 3.11. Coolant Temperatures in Channel 2.

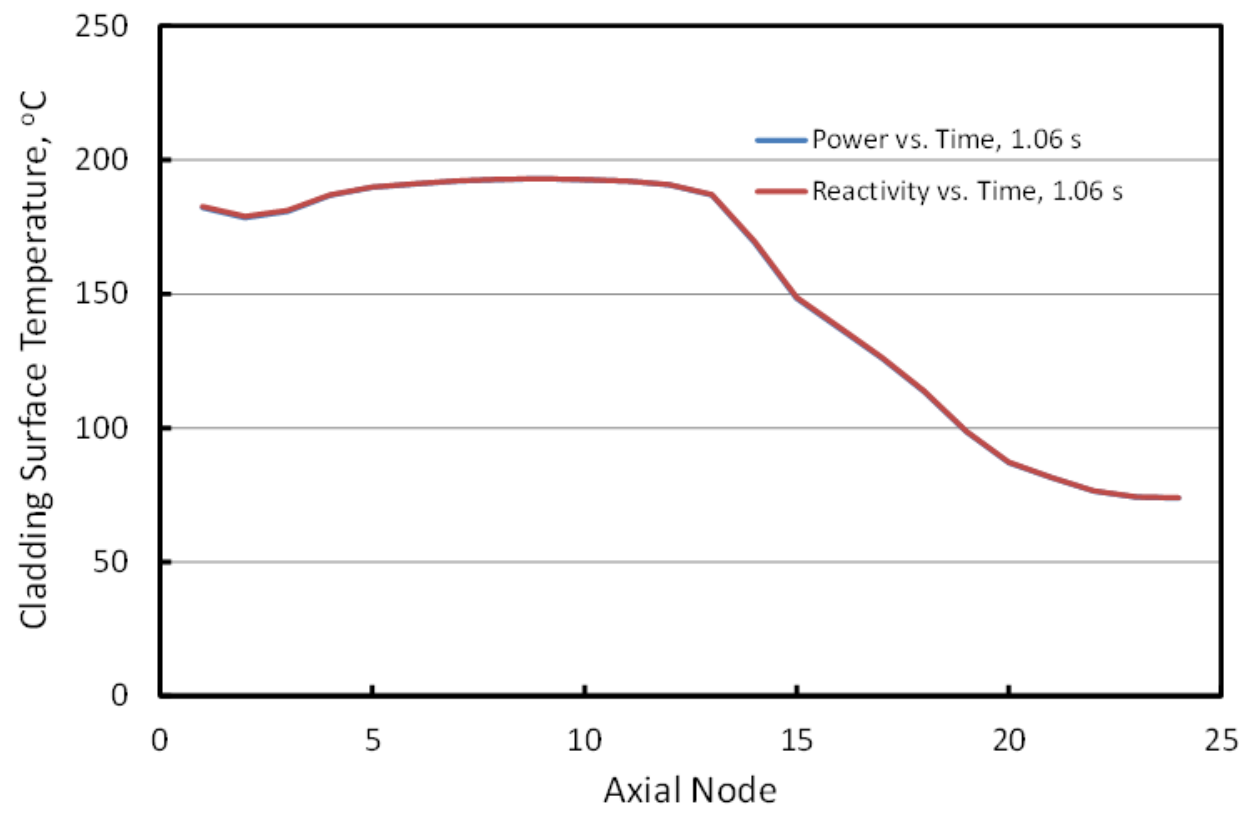

Figure 3.12. Cladding Surface Temperatures in Channel 2. 


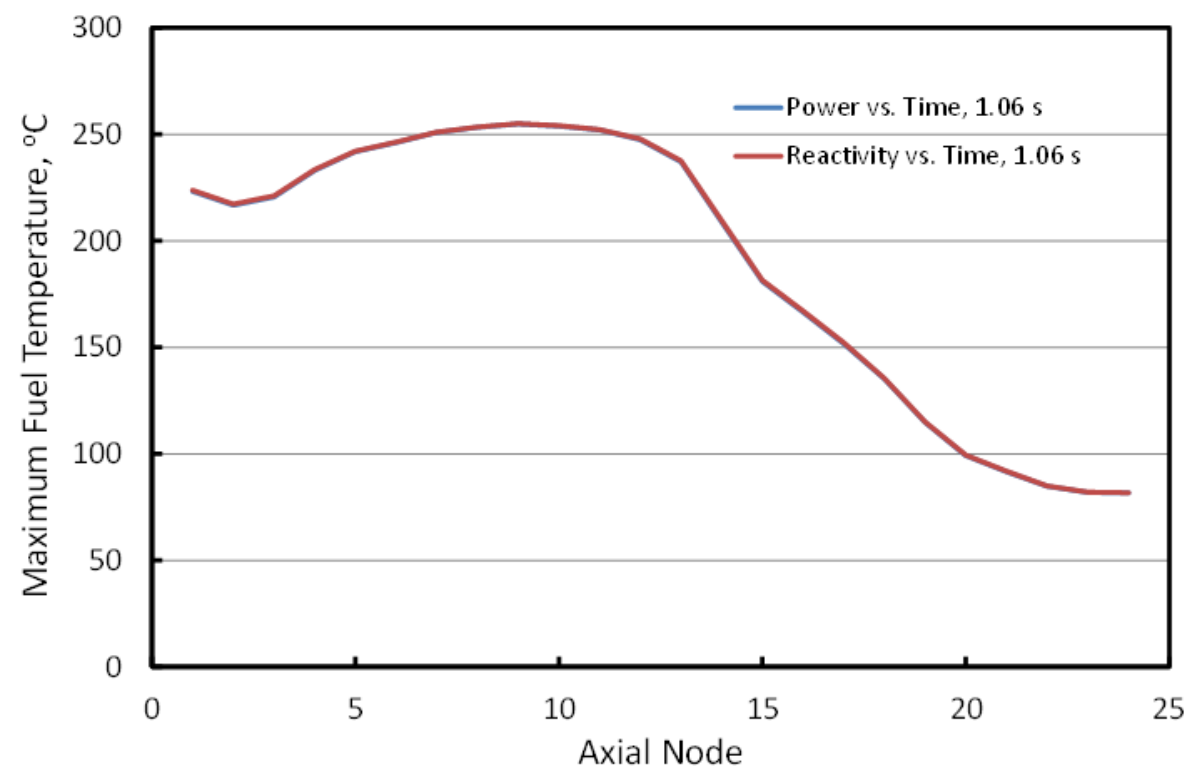

Figure 3.13. Maximum Fuel Temperatures in Channel 2. 


\section{Conclusions}

The data and discussion presented in this report confirm that nine steady-state and six transient capabilities of PARET/ANL are implemented correctly. Furthermore, the code-to-code comparison between PARET/ANL and RELAP5 performed for scenarios involving nucleate boiling shows good agreement. These results provide strong evidence that the capabilities also work together correctly.

It should be noted that the current $V \& V$ work does not consider the implementation of the Rosenthal \& Miller correlation. Additionally, due to the limitation in the V\&V method, the two-phase heat transfer involving boiling beyond the nucleate boiling has not been evaluated. 


\section{Acknowledgement}

The contribution to the PARET/ANL verification and validation of Edgar E. Morris, who is no longer an active staff at Argonne, is gratefully acknowledged.

This work was sponsored by the U.S. Department of Energy, Office of Material Management and Minimization in the U.S. National Nuclear Security Administration Office of Defense Nuclear Nonproliferation under Contract DE-AC02-06CH11357. 


\section{References}

[1] C. F. Obenchain, "PARET-A PROGRAM FOR THE ANALYSIS OF REACTOR TRANSIENTS," Phillips Petroleum Company, Idaho Falls, Idaho, AEC Research and Development Report, Reactor Technology, IDO-17282, January 1969.

[2] A. P. Olson and M. Kalimullah, "A User Guide to PARET/ANL Version 7.6," ANL/RERTR/TM11-38 Rev.3, March, 2019.

[3] W. L. Woodruff and R. S. Smith, "A User Guide for the ANL Version of the PARET Code, PARET/ANL (2001 Rev.)," ANL/RERTR/TM-16, March 2001.

[4] E. R. Cohen, "Some Topics in Reactor Kinetics," in Proc. 2nd. U.N. Intl. Conf. on the Peaceful Uses of Atomic Energy, Vol. 11, p. 302, Geneva, 1958.

[5] The RELAP5-3D Code Development Team, "RELAP5-3D CODE MANUAL VOLUME I: CODE STRUCTURE, SYSTEM, MODELS, AND SOLUTION METHODS," Idaho National Laboratory, INEEL-EXT-98-00834, Revision 2.4, Idaho Falls, Idaho 83415, June 2005.

[6] webbook.nist.gov/chemistry/, National Institute of Standards and Technology (NIST), 100 Bureau Drive, Gaithersburg, Maryland 20899, USA, 2011.

[7] E. W. Lemmon, I. H. Bell, M. L. Huber, M. O. McLinden, "NIST Standard Reference Database 10: Reference Fluid Thermodynamic and Transport Properties-REFPROP, Version 3.0, National Institute of Standards and Technology, Standard Reference Data Program," Gaithersburg, 2013.

[8] "The RELAP5/MOD3.3 Code Manual," , Nuclear Systems Analysis Division, Information Systems Laboratories, Inc., Rockville, Maryland and Idaho Falls, Idaho, Prepared for the Division of Systems Research, Office of Nuclear Regulatory Research, U. S. Nuclear Regulatory Commission, Washington, DC 20555, March 2006.

[9] B. D. Ganapol, "A highly accurate algorithm for the solution of the point kinetics equations," Annals of Nuclear Energy, vol. 62, pp. 564-571, December 2013.

[10] G. I. Bell and S. Glasstone, Nuclear Reactor Theory, New York: Van Nostrand Reinhold Company, 1970.

[11] A. C. Hindmarsh, "GEAR: Ordinary Differential Equation System Solver," Lawrence Livermore Laboratory, Report UCID-30001, Rev. 3, 1974.

[12] IAEA, "Research Reactor Benchmarking Database: Facility Specification and Experimental Data," IAEA, Technical Report Series No. 480, Vienna, 2015.

[13] A. P. Olson, " SPERT III E core: Facility specification", IAEA Research Reactor Benchmarking Database: Facility Specification and Experimental Data, 2015.

[14] A. P. Olson, "Neutronics calculations for SPERT-III, E-core," ANL/GTRI/TM-13/10, May 30, 2013.

[15] A. P. Olson, "Consolidator's Report for the SPERT-III-Benchmark," ANL/GTRI-TM-13/9, May, 2013.

[16] "American National Standard Decay Heat Power in Light Water Reactors," American Nuclear Society, ANSI/ANS-5.1-2005, Approved April 1, 2005. 
[17] "Decay Energy Release Rates Following Shutdown of Uranium-Fueled Thermal Reactors," Proposed ANS Standard, Approved by Subcommittee ANS-5, American Nuclear Society Standards Committee (October 1971) (Revised October 1973). 


\section{APPENDIX A: Acceptance Testing Criteria}

As mentioned above, the objective of an acceptance test is to confirm that a newly compiled or installed code provides similar results that are sufficiently accurate compared to those obtained with the version considered in the current $\mathrm{V} \& \mathrm{~V}$. The acceptance values are used to assure the duplication of the output parameters, while the tolerances allow accepting insignificant differences caused by the compiler and/or host operation system.

For each test case included in the acceptance test, output parameters to be monitored are selected to ensure that correct results are provided by the corresponding code capability. The data provided by the main output file ( ${ }^{*}$.out) are used to check most of the steady-state capabilities and data provided by the channel output files (*.out.ch*) are used for the transient capabilities. The reference time points of transient results are selected in order to confirm the data at important events such as initiating the reactor trip, starting of scram, peak power, etc.

In the following tables, the acceptance values are the same as parameters edited in the output files. The tolerances are decided based on the number of meaningful digits after the decimal point that are edited in the output file or essential for the safety analysis.

Table A.1. Test Cases A01_01 to A01_11 - Light Water Properties

\begin{tabular}{|c|c|c|c|c|}
\hline $\begin{array}{l}\text { Test } \\
\text { Case }\end{array}$ & $\begin{array}{l}\text { Reference } \\
\text { Temp., }{ }^{\circ} \mathrm{C}\end{array}$ & Output Parameter & $\begin{array}{c}\text { Acceptance } \\
\text { Value }\end{array}$ & Tolerance \\
\hline \multirow{11}{*}{ A01_01 } & \multirow{5}{*}{40.0} & Enthalpy, J/kg & $1.66959 E+05$ & $1.0 \mathrm{E}+01$ \\
\hline & & Thermal Conductivity, W/m-K & $6.34891 \mathrm{E}-01$ & $1.0 \mathrm{E}-05$ \\
\hline & & Specific heat capacity, kJ/kg-K & $4.17606 \mathrm{E}+03$ & $1.0 \mathrm{E}-01$ \\
\hline & & Density, $\mathrm{kg} / \mathrm{m} 3$ & $9.92497 \mathrm{E}+02$ & $1.0 \mathrm{E}-02$ \\
\hline & & Viscosity, Pa.s & 6.52399E-04 & $1.0 \mathrm{E}-08$ \\
\hline & Saturation & Saturation temperature, oC & $9.96320 \mathrm{E}+01$ & $1.0 \mathrm{E}-03$ \\
\hline & \multirow{5}{*}{139.0} & Enthalpy, J/kg & $2.75031 E+06$ & $1.0 \mathrm{E}+02$ \\
\hline & & Thermal Conductivity, $\mathrm{W} / \mathrm{m}-\mathrm{K}$ & $2.77929 \mathrm{E}-02$ & $1.0 \mathrm{E}-06$ \\
\hline & & Specific heat capacity, kJ/kg-K & $2.04849 E+03$ & $1.0 \mathrm{E}-01$ \\
\hline & & Density, $\mathrm{kg} / \mathrm{m} 3$ & $5.28966 \mathrm{E}-01$ & $1.0 \mathrm{E}-05$ \\
\hline & & Viscosity, Pa.s & $1.36424 \mathrm{E}-05$ & $1.0 \mathrm{E}-09$ \\
\hline \multirow{11}{*}{ A01_02 } & \multirow{5}{*}{56.0} & Enthalpy, J/kg & $2.33957 \mathrm{E}+05$ & $1.0 \mathrm{E}+01$ \\
\hline & & Thermal Conductivity, $\mathrm{W} / \mathrm{m}-\mathrm{K}$ & $6.53131 \mathrm{E}-01$ & $1.0 \mathrm{E}-05$ \\
\hline & & Specific heat capacity, kJ/kg-K & $4.18648 \mathrm{E}+03$ & $1.0 \mathrm{E}-01$ \\
\hline & & Density, $\mathrm{kg} / \mathrm{m} 3$ & $9.85890 \mathrm{E}+02$ & $1.0 \mathrm{E}-02$ \\
\hline & & Viscosity, Pa.s & 4.91984E-04 & $1.0 \mathrm{E}-08$ \\
\hline & Saturation & Saturation temperature, oC & $1.20231 E+02$ & $1.0 \mathrm{E}-02$ \\
\hline & \multirow{5}{*}{157.0} & Enthalpy, J/kg & $2.78138 \mathrm{E}+06$ & $1.0 \mathrm{E}+02$ \\
\hline & & Thermal Conductivity, $\mathrm{W} / \mathrm{m}-\mathrm{K}$ & $2.95106 \mathrm{E}-02$ & $1.0 \mathrm{E}-06$ \\
\hline & & Specific heat capacity, kJ/kg-K & $2.10285 \mathrm{E}+03$ & $1.0 \mathrm{E}-01$ \\
\hline & & Density, $\mathrm{kg} / \mathrm{m} 3$ & $1.01957 \mathrm{E}+00$ & $1.0 \mathrm{E}-04$ \\
\hline & & Viscosity, Pa.s & 1.43349E-05 & $1.0 \mathrm{E}-09$ \\
\hline \multirow{8}{*}{ A01_03 } & \multirow{5}{*}{64.0} & Enthalpy, J/kg & $2.67740 \mathrm{E}+05$ & $1.0 \mathrm{E}+01$ \\
\hline & & Thermal Conductivity, W/m-K & $6.61024 \mathrm{E}-01$ & $1.0 \mathrm{E}-05$ \\
\hline & & Specific heat capacity, kJ/kg-K & $4.19342 E+03$ & $1.0 \mathrm{E}-01$ \\
\hline & & Density, $\mathrm{kg} / \mathrm{m} 3$ & $9.81945 \mathrm{E}+02$ & $1.0 \mathrm{E}-02$ \\
\hline & & Viscosity, Pa.s & $4.36851 \mathrm{E}-04$ & $1.0 \mathrm{E}-08$ \\
\hline & Saturation & Saturation temperature, oC & $1.51849 E+02$ & $1.0 \mathrm{E}-02$ \\
\hline & \multirow{2}{*}{185.0} & Enthalpy, J/kg & $2.82069 E+06$ & $1.0 \mathrm{E}+02$ \\
\hline & & Thermal Conductivity, $\mathrm{W} / \mathrm{m}-\mathrm{K}$ & $3.25566 \mathrm{E}-02$ & $1.0 \mathrm{E}-06$ \\
\hline
\end{tabular}


ANL/RTR/TM-16/6 Rev. 1

\begin{tabular}{|c|c|c|c|c|}
\hline & & Specific heat capacity, kJ/kg-K & $2.27737 \mathrm{E}+03$ & $1.0 \mathrm{E}-01$ \\
\hline & & Density, $\mathrm{kg} / \mathrm{m} 3$ & $2.43822 \mathrm{E}+00$ & $1.0 \mathrm{E}-04$ \\
\hline & & Viscosity, Pa.s & $1.53826 \mathrm{E}-05$ & $1.0 \mathrm{E}-09$ \\
\hline \multirow{11}{*}{ A01_04 } & \multirow{5}{*}{72.0} & Enthalpy, $\mathrm{J} / \mathrm{kg}$ & $3.01732 E+05$ & $1.0 \mathrm{E}+01$ \\
\hline & & Thermal Conductivity, $\mathrm{W} / \mathrm{m}-\mathrm{K}$ & $6.68106 \mathrm{E}-01$ & $1.0 \mathrm{E}-05$ \\
\hline & & Specific heat capacity, kJ/kg-K & 4.19689E+03 & $1.0 \mathrm{E}-01$ \\
\hline & & Density, $\mathrm{kg} / \mathrm{m} 3$ & $9.77622 \mathrm{E}+02$ & $1.0 \mathrm{E}-02$ \\
\hline & & Viscosity, Pa.s & 3.91277E-04 & $1.0 \mathrm{E}-08$ \\
\hline & Saturation & Saturation temperature, oC & $1.79883 \mathrm{E}+02$ & $1.0 \mathrm{E}-02$ \\
\hline & \multirow{5}{*}{207.0} & Enthalpy, $\mathrm{J} / \mathrm{kg}$ & $2.81862 E+06$ & $1.0 \mathrm{E}+02$ \\
\hline & & Thermal Conductivity, W/m-K & $3.56977 \mathrm{E}-02$ & $1.0 \mathrm{E}-06$ \\
\hline & & Specific heat capacity, kJ/kg-K & $2.72942 \mathrm{E}+03$ & $1.0 \mathrm{E}-01$ \\
\hline & & Density, $\mathrm{kg} / \mathrm{m} 3$ & $4.89382 \mathrm{E}+00$ & $1.0 \mathrm{E}-04$ \\
\hline & & Viscosity, Pa.s & $1.61533 \mathrm{E}-05$ & $1.0 \mathrm{E}-09$ \\
\hline \multirow{11}{*}{ A01_05 } & \multirow{5}{*}{88.0} & Enthalpy, J/kg & $3.69840 E+05$ & $1.0 \mathrm{E}+01$ \\
\hline & & Thermal Conductivity, $\mathrm{W} / \mathrm{m}-\mathrm{K}$ & $6.79764 \mathrm{E}-01$ & $1.0 \mathrm{E}-05$ \\
\hline & & Specific heat capacity, kJ/kg-K & $4.21425 \mathrm{E}+03$ & $1.0 \mathrm{E}-01$ \\
\hline & & Density, $\mathrm{kg} / \mathrm{m} 3$ & $9.67718 \mathrm{E}+02$ & $1.0 \mathrm{E}-02$ \\
\hline & & Viscosity, Pa.s & $3.26431 \mathrm{E}-04$ & $1.0 \mathrm{E}-08$ \\
\hline & Saturation & Saturation temperature, oC & $2.12369 \mathrm{E}+02$ & $1.0 \mathrm{E}-02$ \\
\hline & \multirow{5}{*}{237.0} & Enthalpy, $\mathrm{J} / \mathrm{kg}$ & $2.85878 \mathrm{E}+06$ & $1.0 \mathrm{E}+02$ \\
\hline & & Thermal Conductivity, W/m-K & $4.06529 \mathrm{E}-02$ & $1.0 \mathrm{E}-06$ \\
\hline & & Specific heat capacity, kJ/kg-K & $2.79808 \mathrm{E}+03$ & $1.0 \mathrm{E}-01$ \\
\hline & & Density, $\mathrm{kg} / \mathrm{m} 3$ & $9.38521 \mathrm{E}+00$ & $1.0 \mathrm{E}-04$ \\
\hline & & Viscosity, Pa.s & $1.72545 \mathrm{E}-05$ & $1.0 \mathrm{E}-09$ \\
\hline \multirow{11}{*}{ A01_06 } & \multirow{5}{*}{96.0} & Enthalpy, J/kg & $4.04346 \mathrm{E}+05$ & $1.0 \mathrm{E}+01$ \\
\hline & & Thermal Conductivity, $\mathrm{W} / \mathrm{m}-\mathrm{K}$ & $6.84416 \mathrm{E}-01$ & $1.0 \mathrm{E}-05$ \\
\hline & & Specific heat capacity, kJ/kg-K & $4.22119 \mathrm{E}+03$ & $1.0 \mathrm{E}-01$ \\
\hline & & Density, $\mathrm{kg} / \mathrm{m} 3$ & $9.62441 \mathrm{E}+02$ & $1.0 \mathrm{E}-02$ \\
\hline & & Viscosity, Pa.s & $3.00556 \mathrm{E}-04$ & $1.0 \mathrm{E}-08$ \\
\hline & Saturation & Saturation temperature, oC & $2.33838 \mathrm{E}+02$ & $1.0 \mathrm{E}-02$ \\
\hline & \multirow{5}{*}{255.0} & Enthalpy, $\mathrm{J} / \mathrm{kg}$ & $2.86928 \mathrm{E}+06$ & $1.0 \mathrm{E}+02$ \\
\hline & & Thermal Conductivity, $\mathrm{W} / \mathrm{m}-\mathrm{K}$ & 4.47594E-02 & $1.0 \mathrm{E}-06$ \\
\hline & & Specific heat capacity, kJ/kg-K & $2.93541 \mathrm{E}+03$ & $1.0 \mathrm{E}-01$ \\
\hline & & Density, $\mathrm{kg} / \mathrm{m} 3$ & $1.39499 \mathrm{E}+01$ & $1.0 \mathrm{E}-03$ \\
\hline & & Viscosity, Pa.s & $1.79254 \mathrm{E}-05$ & $1.0 \mathrm{E}-09$ \\
\hline \multirow{11}{*}{ A01_07 } & \multirow{5}{*}{104.0} & Enthalpy, J/kg & $4.38879 E+05$ & $1.0 \mathrm{E}+01$ \\
\hline & & Thermal Conductivity, $\mathrm{W} / \mathrm{m}-\mathrm{K}$ & $6.88250 \mathrm{E}-01$ & $1.0 \mathrm{E}-05$ \\
\hline & & Specific heat capacity, kJ/kg-K & $4.22813 E+03$ & $1.0 \mathrm{E}-01$ \\
\hline & & Density, $\mathrm{kg} / \mathrm{m} 3$ & $9.56868 \mathrm{E}+02$ & $1.0 \mathrm{E}-02$ \\
\hline & & Viscosity, Pa.s & $2.77417 \mathrm{E}-04$ & $1.0 \mathrm{E}-08$ \\
\hline & Saturation & Saturation temperature, oC & $2.50333 \mathrm{E}+02$ & $1.0 \mathrm{E}-02$ \\
\hline & \multirow{5}{*}{269.0} & Enthalpy, $\mathrm{J} / \mathrm{kg}$ & $2.87040 \mathrm{E}+06$ & $1.0 \mathrm{E}+02$ \\
\hline & & Thermal Conductivity, $\mathrm{W} / \mathrm{m}-\mathrm{K}$ & $4.86732 \mathrm{E}-02$ & $1.0 \mathrm{E}-06$ \\
\hline & & Specific heat capacity, kJ/kg-K & $3.11279 \mathrm{E}+03$ & $1.0 \mathrm{E}-01$ \\
\hline & & Density, $\mathrm{kg} / \mathrm{m} 3$ & $1.86152 \mathrm{E}+01$ & $1.0 \mathrm{E}-03$ \\
\hline & & Viscosity, Pa.s & $1.84840 \mathrm{E}-05$ & $1.0 \mathrm{E}-09$ \\
\hline \multirow{8}{*}{ A01_08 } & \multirow{5}{*}{112.0} & Enthalpy, J/kg & $4.73454 \mathrm{E}+05$ & $1.0 \mathrm{E}+01$ \\
\hline & & Thermal Conductivity, W/m-K & $6.91283 \mathrm{E}-01$ & $1.0 \mathrm{E}-05$ \\
\hline & & Specific heat capacity, kJ/kg-K & $4.23508 \mathrm{E}+03$ & $1.0 \mathrm{E}-01$ \\
\hline & & Density, $\mathrm{kg} / \mathrm{m} 3$ & $9.51047 \mathrm{E}+02$ & $1.0 \mathrm{E}-02$ \\
\hline & & Viscosity, Pa.s & $2.56736 \mathrm{E}-04$ & $1.0 \mathrm{E}-08$ \\
\hline & Saturation & Saturation temperature, oC & $2.63914 \mathrm{E}+02$ & $1.0 \mathrm{E}-02$ \\
\hline & \multirow{2}{*}{279.0} & Enthalpy, J/kg & $2.86033 \mathrm{E}+06$ & $1.0 \mathrm{E}+02$ \\
\hline & & Thermal Conductivity, $\mathrm{W} / \mathrm{m}-\mathrm{K}$ & $5.26262 \mathrm{E}-02$ & $1.0 \mathrm{E}-06$ \\
\hline
\end{tabular}


ANL/RTR/TM-16/6 Rev. 1

\begin{tabular}{|c|c|c|c|c|}
\hline & & Specific heat capacity, kJ/kg-K & $3.34167 \mathrm{E}+03$ & $1.0 \mathrm{E}-01$ \\
\hline & & Density, $\mathrm{kg} / \mathrm{m3}$ & $2.35661 \mathrm{E}+01$ & $1.0 \mathrm{E}-03$ \\
\hline & & Viscosity, Pa.s & $1.88959 \mathrm{E}-05$ & 1.0E-09 \\
\hline \multirow{11}{*}{ A01_09 } & \multirow{5}{*}{120.0} & Enthalpy, J/kg & $5.09126 \mathrm{E}+05$ & $1.0 \mathrm{E}+01$ \\
\hline & & Thermal Conductivity, $\mathrm{W} / \mathrm{m}-\mathrm{K}$ & $6.93585 \mathrm{E}-01$ & $1.0 \mathrm{E}-05$ \\
\hline & & Specific heat capacity, $\mathrm{kJ} / \mathrm{kg}-\mathrm{K}$ & $4.23508 \mathrm{E}+03$ & 1.0E-01 \\
\hline & & Density, kg/m3 & $9.45765 \mathrm{E}+02$ & 1.0E-02 \\
\hline & & Viscosity, Pa.s & $2.37768 \mathrm{E}-04$ & 1.0E-08 \\
\hline & Saturation & Saturation temperature, oC & $2.90512 \mathrm{E}+02$ & $1.0 \mathrm{E}-02$ \\
\hline & \multirow{5}{*}{303.0} & Enthalpy, J/kg & $2.83529 \mathrm{E}+06$ & $1.0 \mathrm{E}+02$ \\
\hline & & Thermal Conductivity, $\mathrm{W} / \mathrm{m}-\mathrm{K}$ & $6.28187 \mathrm{E}-02$ & $1.0 \mathrm{E}-06$ \\
\hline & & Specific heat capacity, kJ/kg-K & $3.98254 \mathrm{E}+03$ & $1.0 \mathrm{E}-01$ \\
\hline & & Density, $\mathrm{kg} / \mathrm{m} 3$ & $3.64777 \mathrm{E}+01$ & $1.0 \mathrm{E}-03$ \\
\hline & & Viscosity, Pa.s & $2.01218 \mathrm{E}-05$ & 1.0E-09 \\
\hline \multirow{11}{*}{ A01_10 } & \multirow{5}{*}{128.0} & Enthalpy, J/kg & $5.44784 \mathrm{E}+05$ & $1.0 \mathrm{E}+01$ \\
\hline & & Thermal Conductivity, $\mathrm{W} / \mathrm{m}-\mathrm{K}$ & $6.95067 \mathrm{E}-01$ & $1.0 \mathrm{E}-05$ \\
\hline & & Specific heat capacity, kJ/kg-K & $4.24202 E+03$ & $1.0 \mathrm{E}-01$ \\
\hline & & Density, $\mathrm{kg} / \mathrm{m3}$ & $9.40394 \mathrm{E}+02$ & 1.0E-02 \\
\hline & & Viscosity, Pa.s & $2.20984 \mathrm{E}-04$ & $1.0 \mathrm{E}-08$ \\
\hline & Saturation & Saturation temperature, oC & $3.10960 \mathrm{E}+02$ & $1.0 \mathrm{E}-02$ \\
\hline & \multirow{5}{*}{320.0} & Enthalpy, J/kg & $2.78545 \mathrm{E}+06$ & $1.0 \mathrm{E}+02$ \\
\hline & & Thermal Conductivity, $\mathrm{W} / \mathrm{m}-\mathrm{K}$ & 7.49071E-02 & $1.0 \mathrm{E}-06$ \\
\hline & & Specific heat capacity, kJ/kg-K & $4.98390 \mathrm{E}+03$ & $1.0 \mathrm{E}-01$ \\
\hline & & Density, kg/m3 & $5.16182 \mathrm{E}+01$ & $1.0 \mathrm{E}-03$ \\
\hline & & Viscosity, Pa.s & $2.15421 \mathrm{E}-05$ & 1.0E-09 \\
\hline \multirow{11}{*}{ A01_11 } & \multirow{5}{*}{136.0} & Enthalpy, J/kg & $5.80428 \mathrm{E}+05$ & $1.0 \mathrm{E}+01$ \\
\hline & & Thermal Conductivity, $\mathrm{W} / \mathrm{m}-\mathrm{K}$ & $6.95747 \mathrm{E}-01$ & $1.0 \mathrm{E}-05$ \\
\hline & & Specific heat capacity, kJ/kg-K & $4.24896 \mathrm{E}+03$ & $1.0 \mathrm{E}-01$ \\
\hline & & Density, $\mathrm{kg} / \mathrm{m} 3$ & $9.35000 \mathrm{E}+02$ & $1.0 \mathrm{E}-02$ \\
\hline & & Viscosity, Pa.s & $2.06161 \mathrm{E}-04$ & 1.0E-08 \\
\hline & Saturation & Saturation temperature, oC & $3.27780 \mathrm{E}+02$ & $1.0 \mathrm{E}-02$ \\
\hline & \multirow{5}{*}{334.0} & Enthalpy, J/kg & $2.71984 \mathrm{E}+06$ & $1.0 \mathrm{E}+02$ \\
\hline & & Thermal Conductivity, $\mathrm{W} / \mathrm{m}-\mathrm{K}$ & $9.03523 \mathrm{E}-02$ & $1.0 \mathrm{E}-06$ \\
\hline & & Specific heat capacity, kJ/kg-K & $6.58035 \mathrm{E}+03$ & $1.0 \mathrm{E}-01$ \\
\hline & & Density, $\mathrm{kg} / \mathrm{m} 3$ & $6.99239 \mathrm{E}+01$ & $1.0 \mathrm{E}-03$ \\
\hline & & Viscosity, Pa.s & $2.34782 \mathrm{E}-05$ & 1.0E-09 \\
\hline
\end{tabular}

Table A.2. Test Cases A01_12 to A01_22 - Heavy Water Properties

\begin{tabular}{|c|c|c|c|c|}
\hline $\begin{array}{l}\text { Test } \\
\text { Case }\end{array}$ & $\begin{array}{l}\text { Reference } \\
\text { Temp., }{ }^{\circ} \mathrm{C}\end{array}$ & Output Parameter & $\begin{array}{c}\text { Acceptance } \\
\text { Value }\end{array}$ & Tolerance \\
\hline \multirow{11}{*}{ A1_12 } & \multirow{5}{*}{48.0} & Enthalpy, J/kg & $1.82168 \mathrm{E}+05$ & $1.0 \mathrm{E}+01$ \\
\hline & & Thermal Conductivity, $\mathrm{W} / \mathrm{m}-\mathrm{K}$ & $6.16619 \mathrm{E}-01$ & $1.0 \mathrm{E}-05$ \\
\hline & & Specific heat capacity, kJ/kg-K & $4.11059 \mathrm{E}+03$ & $1.0 \mathrm{E}-01$ \\
\hline & & Density, $\mathrm{kg} / \mathrm{m} 3$ & $1.09784 \mathrm{E}+03$ & $1.0 \mathrm{E}-01$ \\
\hline & & Viscosity, Pa.s & $6.78066 \mathrm{E}-04$ & 1.0E-08 \\
\hline & Saturation & Saturation temperature, oC & $1.01065 \mathrm{E}+02$ & $1.0 \mathrm{E}-02$ \\
\hline & \multirow{5}{*}{141.0} & Enthalpy, J/kg & $2.54846 \mathrm{E}+06$ & $1.0 \mathrm{E}+02$ \\
\hline & & Thermal Conductivity, W/m-K & $2.73183 \mathrm{E}-02$ & $1.0 \mathrm{E}-06$ \\
\hline & & Specific heat capacity, kJ/kg-K & $1.86335 \mathrm{E}+03$ & $1.0 \mathrm{E}-01$ \\
\hline & & Density, $\mathrm{kg} / \mathrm{m} 3$ & $5.87188 \mathrm{E}-01$ & $1.0 \mathrm{E}-05$ \\
\hline & & Viscosity, Pa.s & 1.43659E-05 & 1.0E-09 \\
\hline \multirow{3}{*}{ A1_13 } & \multirow{3}{*}{56.0} & Enthalpy, J/kg & $2.15108 \mathrm{E}+05$ & $1.0 \mathrm{E}+01$ \\
\hline & & Thermal Conductivity, W/m-K & $6.21460 \mathrm{E}-01$ & $1.0 \mathrm{E}-05$ \\
\hline & & Specific heat capacity, kJ/kg-K & $4.10579 E+03$ & $1.0 \mathrm{E}-01$ \\
\hline
\end{tabular}


ANL/RTR/TM-16/6 Rev. 1

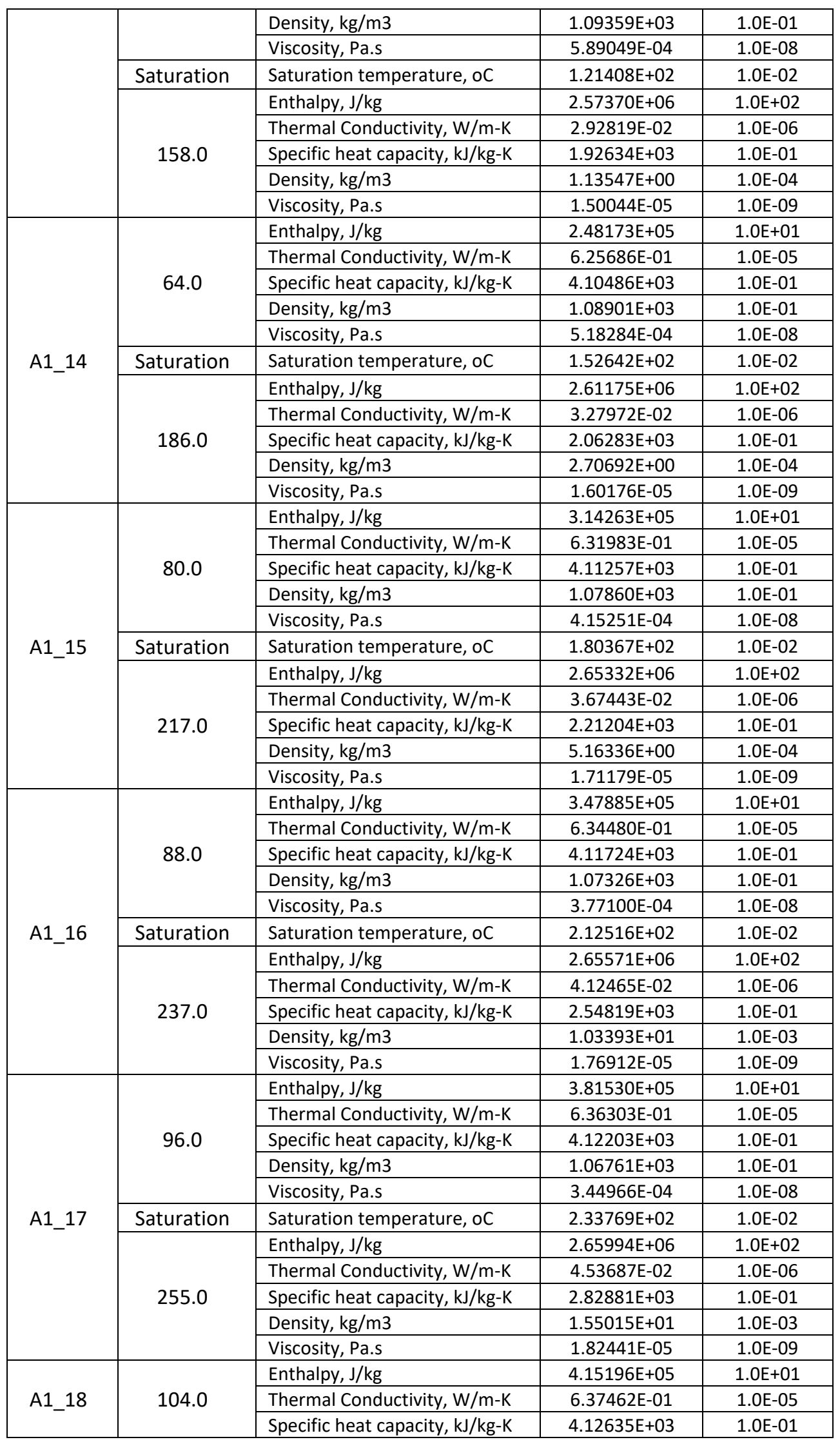


ANL/RTR/TM-16/6 Rev. 1

\begin{tabular}{|c|c|c|c|c|}
\hline & & Density, $\mathrm{kg} / \mathrm{m} 3$ & $1.06166 \mathrm{E}+03$ & $1.0 \mathrm{E}-01$ \\
\hline & & Viscosity, Pa.s & $3.17492 \mathrm{E}-04$ & $1.0 \mathrm{E}-08$ \\
\hline & Saturation & Saturation temperature, oC & $2.50098 \mathrm{E}+02$ & $1.0 \mathrm{E}-02$ \\
\hline & \multirow{5}{*}{269.0} & Enthalpy, J/kg & $2.65834 \mathrm{E}+06$ & $1.0 \mathrm{E}+02$ \\
\hline & & Thermal Conductivity, W/m-K & 4.92643E-02 & $1.0 \mathrm{E}-06$ \\
\hline & & Specific heat capacity, kJ/kg-K & $3.10175 E+03$ & 1.0E-01 \\
\hline & & Density, $\mathrm{kg} / \mathrm{m} 3$ & $2.07960 \mathrm{E}+01$ & $1.0 \mathrm{E}-03$ \\
\hline & & Viscosity, Pa.s & $1.86767 \mathrm{E}-05$ & 1.0E-09 \\
\hline \multirow{11}{*}{ A1_19 } & \multirow{5}{*}{112.0} & Enthalpy, J/kg & $4.48878 \mathrm{E}+05$ & $1.0 \mathrm{E}+01$ \\
\hline & & Thermal Conductivity, $\mathrm{W} / \mathrm{m}-\mathrm{K}$ & $6.37966 \mathrm{E}-01$ & $1.0 \mathrm{E}-05$ \\
\hline & & Specific heat capacity, kJ/kg-K & $4.13002 E+03$ & 1.0E-01 \\
\hline & & Density, $\mathrm{kg} / \mathrm{m} 3$ & $1.05543 \mathrm{E}+03$ & $1.0 \mathrm{E}-01$ \\
\hline & & Viscosity, Pa.s & $2.93698 \mathrm{E}-04$ & $1.0 \mathrm{E}-08$ \\
\hline & Saturation & Saturation temperature, oC & $2.63542 E+02$ & $1.0 \mathrm{E}-02$ \\
\hline & \multirow{5}{*}{279.0} & Enthalpy, J/kg & $2.64772 E+06$ & $1.0 \mathrm{E}+02$ \\
\hline & & Thermal Conductivity, $\mathrm{W} / \mathrm{m}-\mathrm{K}$ & 5.32649E-02 & $1.0 \mathrm{E}-06$ \\
\hline & & Specific heat capacity, $\mathrm{kJ} / \mathrm{kg}-\mathrm{K}$ & $3.41681 E+03$ & 1.0E-01 \\
\hline & & Density, $\mathrm{kg} / \mathrm{m} 3$ & $2.64227 \mathrm{E}+01$ & $1.0 \mathrm{E}-03$ \\
\hline & & Viscosity, Pa.s & $1.89634 \mathrm{E}-05$ & 1.0E-09 \\
\hline \multirow{11}{*}{ A1_20 } & \multirow{5}{*}{120.0} & Enthalpy, $\mathrm{J} / \mathrm{kg}$ & $4.83517 \mathrm{E}+05$ & $1.0 \mathrm{E}+01$ \\
\hline & & Thermal Conductivity, W/m-K & $6.38656 \mathrm{E}-01$ & $1.0 \mathrm{E}-05$ \\
\hline & & Specific heat capacity, kJ/kg-K & $4.12996 \mathrm{E}+03$ & $1.0 \mathrm{E}-01$ \\
\hline & & Density, $\mathrm{kg} / \mathrm{m} 3$ & $1.04979 E+03$ & $1.0 \mathrm{E}-01$ \\
\hline & & Viscosity, Pa.s & $2.73356 \mathrm{E}-04$ & $1.0 \mathrm{E}-08$ \\
\hline & Saturation & Saturation temperature, oC & $2.89846 \mathrm{E}+02$ & $1.0 \mathrm{E}-02$ \\
\hline & \multirow{5}{*}{302.0} & Enthalpy, J/kg & $2.62410 E+06$ & $1.0 \mathrm{E}+02$ \\
\hline & & Thermal Conductivity, W/m-K & $6.36229 \mathrm{E}-02$ & $1.0 \mathrm{E}-06$ \\
\hline & & Specific heat capacity, kJ/kg-K & $4.21823 E+03$ & 1.0E-01 \\
\hline & & Density, $\mathrm{kg} / \mathrm{m} 3$ & $4.11533 \mathrm{E}+01$ & $1.0 \mathrm{E}-03$ \\
\hline & & Viscosity, Pa.s & $1.97554 \mathrm{E}-05$ & 1.0E-09 \\
\hline \multirow{11}{*}{ A1_21 } & \multirow{5}{*}{128.0} & Enthalpy, J/kg & $5.18116 \mathrm{E}+05$ & $1.0 \mathrm{E}+01$ \\
\hline & & Thermal Conductivity, $\mathrm{W} / \mathrm{m}-\mathrm{K}$ & $6.38747 \mathrm{E}-01$ & $1.0 \mathrm{E}-05$ \\
\hline & & Specific heat capacity, kJ/kg-K & $4.12972 \mathrm{E}+03$ & $1.0 \mathrm{E}-01$ \\
\hline & & Density, $\mathrm{kg} / \mathrm{m} 3$ & $1.04392 \mathrm{E}+03$ & 1.0E-01 \\
\hline & & Viscosity, Pa.s & $2.55448 \mathrm{E}-04$ & $1.0 \mathrm{E}-08$ \\
\hline & Saturation & Saturation temperature, oC & $3.10074 \mathrm{E}+02$ & $1.0 \mathrm{E}-02$ \\
\hline & \multirow{5}{*}{320.0} & Enthalpy, J/kg & $2.59109 E+06$ & $1.0 \mathrm{E}+02$ \\
\hline & & Thermal Conductivity, $\mathrm{W} / \mathrm{m}-\mathrm{K}$ & $7.52378 \mathrm{E}-02$ & 1.0E-06 \\
\hline & & Specific heat capacity, kJ/kg-K & $5.19450 \mathrm{E}+03$ & 1.0E-01 \\
\hline & & Density, $\mathrm{kg} / \mathrm{m} 3$ & $5.76353 \mathrm{E}+01$ & $1.0 \mathrm{E}-03$ \\
\hline & & Viscosity, Pa.s & $2.05425 \mathrm{E}-05$ & 1.0E-09 \\
\hline \multirow{11}{*}{ A1_22 } & \multirow{5}{*}{136.0} & Enthalpy, J/kg & $5.52672 \mathrm{E}+05$ & $1.0 \mathrm{E}+01$ \\
\hline & & Thermal Conductivity, $\mathrm{W} / \mathrm{m}-\mathrm{K}$ & $6.38258 \mathrm{E}-01$ & 1.0E-05 \\
\hline & & Specific heat capacity, kJ/kg-K & $4.12991 \mathrm{E}+03$ & 1.0E-01 \\
\hline & & Density, $\mathrm{kg} / \mathrm{m} 3$ & $1.03784 \mathrm{E}+03$ & $1.0 \mathrm{E}-01$ \\
\hline & & Viscosity, Pa.s & $2.39575 \mathrm{E}-04$ & $1.0 \mathrm{E}-08$ \\
\hline & Saturation & Saturation temperature, oC & $3.26689 E+02$ & $1.0 \mathrm{E}-02$ \\
\hline & \multirow{5}{*}{333.0} & Enthalpy, J/kg & $2.53711 \mathrm{E}+06$ & $1.0 \mathrm{E}+02$ \\
\hline & & Thermal Conductivity, W/m-K & $9.03124 \mathrm{E}-02$ & $1.0 \mathrm{E}-06$ \\
\hline & & Specific heat capacity, $\mathrm{kJ} / \mathrm{kg}-\mathrm{K}$ & $6.69632 \mathrm{E}+03$ & $1.0 \mathrm{E}-01$ \\
\hline & & Density, $\mathrm{kg} / \mathrm{m} 3$ & $7.78401 \mathrm{E}+01$ & $1.0 \mathrm{E}-03$ \\
\hline & & Viscosity, Pa.s & $2.13215 \mathrm{E}-05$ & 1.0E-09 \\
\hline
\end{tabular}


Table A.3. Test Cases A02_01 and A07_01 - Solid Properties and Nucleate Boiling Model

\begin{tabular}{|c|c|c|c|c|}
\hline Test Case & Reference Time, s & Output Parameter & $\begin{array}{c}\text { Acceptance } \\
\text { Value }\end{array}$ & Tolerance \\
\hline \multirow{15}{*}{ A02_01 } & \multirow{3}{*}{$9.90621 E-01$} & Reactor power, MW & $1.19325 \mathrm{E}+01$ & $1.0 \mathrm{E}-03$ \\
\hline & & Max. clad surface temp., ${ }^{\circ} \mathrm{C}$ & $1.1911 \mathrm{E}+02$ & $1.0 \mathrm{E}-01$ \\
\hline & & Max. fuel temp., ${ }^{\circ} \mathrm{C}$ & $1.3399 E+02$ & $1.0 \mathrm{E}-01$ \\
\hline & \multirow{3}{*}{$1.03963 \mathrm{E}+00$} & Reactor power, MW & 4.13284E+01 & $1.0 \mathrm{E}-03$ \\
\hline & & Max. clad surface temp., ${ }^{\circ} \mathrm{C}$ & $1.6454 \mathrm{E}+02$ & $1.0 \mathrm{E}-01$ \\
\hline & & Max. fuel temp., ${ }^{\circ} \mathrm{C}$ & $2.0560 \mathrm{E}+02$ & $1.0 \mathrm{E}-01$ \\
\hline & \multirow{3}{*}{$1.13963 \mathrm{E}+00$} & Reactor power, MW & $2.89987 \mathrm{E}+01$ & $1.0 \mathrm{E}-03$ \\
\hline & & Max. clad surface temp., ${ }^{\circ} \mathrm{C}$ & $1.7753 \mathrm{E}+02$ & $1.0 \mathrm{E}-01$ \\
\hline & & Max. fuel temp., ${ }^{\circ} \mathrm{C}$ & $2.1214 \mathrm{E}+02$ & $1.0 \mathrm{E}-01$ \\
\hline & \multirow{3}{*}{$1.50000 \mathrm{E}+00$} & Reactor power, MW & $3.22650 \mathrm{E}+01$ & $1.0 \mathrm{E}-03$ \\
\hline & & Max. clad surface temp., ${ }^{\circ} \mathrm{C}$ & $1.7921 \mathrm{E}+02$ & $1.0 \mathrm{E}-01$ \\
\hline & & Max. fuel temp., ${ }^{\circ} \mathrm{C}$ & $2.1747 \mathrm{E}+02$ & $1.0 \mathrm{E}-01$ \\
\hline & \multirow{3}{*}{$2.00000 \mathrm{E}+00$} & Reactor power, MW & $1.38861 \mathrm{E}+00$ & $1.0 \mathrm{E}-04$ \\
\hline & & Max. clad surface temp., ${ }^{\circ} \mathrm{C}$ & $6.3435 E+01$ & $1.0 \mathrm{E}-02$ \\
\hline & & Max. fuel temp., ${ }^{\circ} \mathrm{C}$ & $6.5366 \mathrm{E}+01$ & $1.0 \mathrm{E}-02$ \\
\hline \multirow{15}{*}{ A07_01 } & \multirow{3}{*}{$9.90621 E-01$} & Reactor power, MW & $1.19325 \mathrm{E}+01$ & $1.0 \mathrm{E}-03$ \\
\hline & & Max. clad surface temp., ${ }^{\circ} \mathrm{C}$ & $1.1911 \mathrm{E}+02$ & $1.0 \mathrm{E}-01$ \\
\hline & & Max. fuel temp., ${ }^{\circ} \mathrm{C}$ & $1.3399 \mathrm{E}+02$ & $1.0 \mathrm{E}-01$ \\
\hline & \multirow{3}{*}{$1.03963 \mathrm{E}+00$} & Reactor power, MW & $4.13284 \mathrm{E}+01$ & $1.0 \mathrm{E}-03$ \\
\hline & & Max. clad surface temp., ${ }^{\circ} \mathrm{C}$ & $1.6455 \mathrm{E}+02$ & $1.0 \mathrm{E}-01$ \\
\hline & & Max. fuel temp., ${ }^{\circ} \mathrm{C}$ & $2.0560 \mathrm{E}+02$ & $1.0 \mathrm{E}-01$ \\
\hline & \multirow{3}{*}{$1.13963 \mathrm{E}+00$} & Reactor power, MW & $2.89987 \mathrm{E}+01$ & $1.0 \mathrm{E}-03$ \\
\hline & & Max. clad surface temp., ${ }^{\circ} \mathrm{C}$ & $1.8406 \mathrm{E}+02$ & $1.0 \mathrm{E}-01$ \\
\hline & & Max. fuel temp., ${ }^{\circ} \mathrm{C}$ & $2.1844 \mathrm{E}+02$ & $1.0 \mathrm{E}-01$ \\
\hline & \multirow{3}{*}{$1.50000 \mathrm{E}+00$} & Reactor power, MW & $3.22650 \mathrm{E}+01$ & $1.0 \mathrm{E}-03$ \\
\hline & & Max. clad surface temp., ${ }^{\circ} \mathrm{C}$ & $1.8638 \mathrm{E}+02$ & $1.0 \mathrm{E}-01$ \\
\hline & & Max. fuel temp., ${ }^{\circ} \mathrm{C}$ & $2.2432 \mathrm{E}+02$ & $1.0 \mathrm{E}-01$ \\
\hline & \multirow{3}{*}{$2.00000 E+00$} & Reactor power, MW & $1.38861 \mathrm{E}+00$ & $1.0 \mathrm{E}-04$ \\
\hline & & Max. clad surface temp., ${ }^{\circ} \mathrm{C}$ & $6.3438 \mathrm{E}+01$ & $1.0 \mathrm{E}-02$ \\
\hline & & Max. fuel temp., ${ }^{\circ} \mathrm{C}$ & $6.5370 \mathrm{E}+01$ & $1.0 \mathrm{E}-02$ \\
\hline
\end{tabular}

Note: Although these two capabilities are classified as steady-state, the transient test cases need to be used for the code-to-code comparison. Hence, the channel output files (*.out.ch02) are used for the acceptance test. 
Table A.4. Test Cases A03_01, A03_02, and A03_03 - Geometry Options

\begin{tabular}{|c|l|c|c|c|c|}
\hline \multirow{2}{*}{ Output Parameter } & \multicolumn{3}{|c|}{ Acceptance Value } & \multirow{2}{*}{ Tolerance } \\
\cline { 3 - 6 } & A03_01 & A03_02 & A03_03 & \\
\hline \multirow{4}{*}{ Channel 1} & Power, MW & $7.50000 \mathrm{E}-01$ & $1.50000 \mathrm{E}-01$ & $7.49969 \mathrm{E}-01$ & $1.00 \mathrm{E}-05$ \\
\cline { 2 - 6 } & Flowrate, $\mathrm{kg} / \mathrm{s}$ & $4.80000 \mathrm{E}+01$ & $1.05547 \mathrm{E}+01$ & $4.79986 \mathrm{E}+01$ & $1.00 \mathrm{E}-03$ \\
\cline { 2 - 6 } & Outlet temperature, ${ }^{\circ} \mathrm{C}$ & $2.37319 \mathrm{E}+01$ & $2.33926 \mathrm{E}+01$ & $2.37319 \mathrm{E}+01$ & $1.00 \mathrm{E}-03$ \\
\cline { 2 - 6 } & Surface heat flux, $\mathrm{MW} / \mathrm{m}^{2}$ & $2.08333 \mathrm{E}+06$ & $1.10535 \mathrm{E}+06$ & $2.08331 \mathrm{E}+06$ & $1.00 \mathrm{E}+02$ \\
\hline \multirow{4}{*}{ Channel 2} & Power, $\mathrm{MW}$ & $2.50000 \mathrm{E}-01$ & $5.00000 \mathrm{E}-02$ & $2.50031 \mathrm{E}-01$ & $1.00 \mathrm{E}-05$ \\
\cline { 2 - 6 } & Flowrate, $\mathrm{kg} / \mathrm{s}$ & $8.00000 \mathrm{E}+00$ & $1.63346 \mathrm{E}+00$ & $8.00000 \mathrm{E}+00$ & $1.00 \mathrm{E}-03$ \\
\cline { 2 - 6 } & Outlet temperature, ${ }^{\circ} \mathrm{C}$ & $2.74826 \mathrm{E}+01$ & $2.73290 \mathrm{E}+01$ & $2.74836 \mathrm{E}+01$ & $1.00 \mathrm{E}-03$ \\
\cline { 2 - 6 } & Surface heat flux, $\mathrm{MW} / \mathrm{m}^{2}$ & $2.08333 \mathrm{E}+06$ & $1.10535 \mathrm{E}+06$ & $2.08359 \mathrm{E}+06$ & $1.00 \mathrm{E}+02$ \\
\hline \multirow{2}{*}{ Full Core } & Power, $\mathrm{MW}$ & $1.00000 \mathrm{E}+00$ & $2.00000 \mathrm{E}-01$ & $1.00000 \mathrm{E}+00$ & $1.00 \mathrm{E}-05$ \\
\cline { 2 - 6 } & Flowrate, $\mathrm{kg} / \mathrm{s}$ & $5.60000 \mathrm{E}+01$ & $1.21882 \mathrm{E}+01$ & $5.59986 \mathrm{E}+01$ & $1.00 \mathrm{E}-03$ \\
\hline
\end{tabular}

Table A.5. Test Cases A04_01, A04_02, A04_03, and A04_05 - Flow Options

\begin{tabular}{|l|c|c|c|c|c|}
\hline \multirow{2}{*}{ Output Parameter } & \multicolumn{4}{|c|}{ Acceptance Value } & \multirow{2}{*}{ Tolerance } \\
\cline { 2 - 5 } & A04_01 & A04_02 & A04_03 & A04_05 & \\
\hline Channel mass flux, $\mathrm{kg} / \mathrm{m}^{2} \mathrm{~s}$ & $1.2789 \mathrm{E}+02$ & $1.2789 \mathrm{E}+02$ & $1.2789 \mathrm{E}+02$ & $1.2789 \mathrm{E}+02$ & $1.0 \mathrm{E}-02$ \\
\hline Outlet temperature, ${ }^{\circ} \mathrm{C}$ & $7.69202 \mathrm{E}+01$ & $7.69208 \mathrm{E}+01$ & $7.69200 \mathrm{E}+01$ & $7.69209 \mathrm{E}+01$ & $1.0 \mathrm{E}-03$ \\
\hline Channel $\Delta \mathrm{P}_{\text {friction, }} \mathrm{Pa}$ & $1.0309 \mathrm{E}-01$ & $1.0309 \mathrm{E}-01$ & $1.0309 \mathrm{E}-01$ & $1.0309 \mathrm{E}-01$ & $1.0 \mathrm{E}-05$ \\
\hline Total $\Delta \mathrm{P}_{\text {buoyancy, }} \mathrm{Pa}$ & $\mathrm{N} / \mathrm{A}$ & $1.00126 \mathrm{E}+02$ & $1.00124 \mathrm{E}+02$ & $1.00126 \mathrm{E}+02$ & $1.0 \mathrm{E}-02$ \\
\hline
\end{tabular}

Table A.6. Test Cases A05_01 to A5_10 - Single-phase Heat Transfer

\begin{tabular}{|c|c|c|c|}
\hline \multirow[b]{2}{*}{ Test Case } & \multicolumn{2}{|c|}{ Acceptance Value } & \multirow[b]{2}{*}{ Tolerance } \\
\hline & $\begin{array}{l}\text { Reynolds } \\
\text { Number }\end{array}$ & $\begin{array}{l}\text { H.T. Coefficient } \\
\mathrm{W} / \mathrm{m}^{2} \mathrm{~s}\end{array}$ & \\
\hline A05_01 & 1987.01 & 2475.06 & $1.0 \mathrm{E}-01$ \\
\hline A05_02 & 1987.01 & 1165.77 & $1.0 \mathrm{E}-01$ \\
\hline A05_03 & 1987.01 & 1414.24 & $1.0 \mathrm{E}-01$ \\
\hline A05_04 & 3233.62 & 1936.89 & $1.0 \mathrm{E}-01$ \\
\hline A05_05 & 35464.75 & 7950.65 & $1.0 \mathrm{E}-01$ \\
\hline A05_06 & 35464.75 & 9475.26 & $1.0 \mathrm{E}-01$ \\
\hline A05_07 & 35464.75 & 10269.84 & $1.0 \mathrm{E}-01$ \\
\hline A05_08 & 63884.26 & 9294.79 & $1.0 \mathrm{E}-01$ \\
\hline A05_09 & 35464.75 & 9725.77 & $1.0 \mathrm{E}-01$ \\
\hline A05_10 & 35464.75 & 8884.06 & $1.0 \mathrm{E}-01$ \\
\hline
\end{tabular}

Note: Data are obtained at outlet axial node 
Table A.7. Test Cases A06_01 and A6_02 - Fin or Bundle Effect

\begin{tabular}{|c|c|c|}
\hline Test Case & $\begin{array}{c}\text { Acceptance Value for H.T. } \\
\text { Coefficient, } \mathbf{W} / \mathbf{m}^{\mathbf{2}} \mathbf{s}\end{array}$ & Tolerance \\
\hline A06_01 & 19876.61 & $1.0 \mathrm{E}-01$ \\
\hline A06_02 & 22208.39 & $1.0 \mathrm{E}-01$ \\
\hline
\end{tabular}

Note: Data are obtained at outlet axial node

Table A.8. Test Cases A08_01 to A08_04 - Friction Factor

\begin{tabular}{|c|c|c|}
\hline Test Case & $\begin{array}{c}\text { Acceptance Value for } \\
\text { Friction Factor }\end{array}$ & Tolerance \\
\hline A08_01 & 0.060933 & $1.0 \mathrm{E}-05$ \\
\hline A08_02 & 0.050778 & $1.0 \mathrm{E}-05$ \\
\hline A08_03 & 0.018682 & $1.0 \mathrm{E}-05$ \\
\hline A08_04 & 0.017343 & $1.0 \mathrm{E}-05$ \\
\hline
\end{tabular}

Table A.9. Test Cases B01_05, B01_21, and B01_29 - Point Kinetic Model

\begin{tabular}{|c|c|c|c|}
\hline \multirow{2}{*}{ Test Case } & $\begin{array}{c}\text { Reference } \\
\text { Time, } \mathbf{s}\end{array}$ & $\begin{array}{c}\text { Acceptance Value for } \\
\text { Reactor Power, MW }\end{array}$ & Tolerance \\
\hline \multirow{4}{*}{$\begin{array}{c}\text { B01_05 } \\
\text { (Step insertion) }\end{array}$} & 20.000 & $8.10772 \mathrm{E}-89$ & $1.0 \mathrm{E}-93$ \\
\cline { 2 - 4 } & 40.000 & $2.55936 \mathrm{E}-87$ & $1.0 \mathrm{E}-91$ \\
\cline { 2 - 4 } & 60.000 & $8.06436 \mathrm{E}-86$ & $1.0 \mathrm{E}-90$ \\
\cline { 2 - 4 } & 80.000 & $2.54095 \mathrm{E}-84$ & $1.0 \mathrm{E}-88$ \\
\hline \multirow{3}{*}{$\begin{array}{c}\text { B01_21 } \\
\text { (Ram insertion) }\end{array}$} & 100.00 & $8.00614 \mathrm{E}-83$ & $1.0 \mathrm{E}-87$ \\
\cline { 2 - 4 } & 4.000 & $2.22844 \mathrm{E}-30$ & $1.0 \mathrm{E}-34$ \\
\cline { 2 - 4 } & 6.000 & $5.58205 \mathrm{E}-30$ & $1.0 \mathrm{E}-34$ \\
\cline { 2 - 4 } & 8.000 & $4.27863 \mathrm{E}-29$ & $1.0 \mathrm{E}-33$ \\
\hline \multirow{3}{*}{$\begin{array}{c}\text { B01_29 } \\
\text { (With feedback }\end{array}$} & 10.000 & $4.51164 \mathrm{E}-25$ & $1.0 \mathrm{E}-29$ \\
\cline { 2 - 4 } & 11.000 & $1.79221 \mathrm{E}-14$ & $1.0 \mathrm{E}-18$ \\
\cline { 2 - 4 } & 1.0000 & $1.20503 \mathrm{E}+01$ & $1.0 \mathrm{E}-03$ \\
\cline { 2 - 4 } & 1.0412 & $1.32499 \mathrm{E}+01$ & $1.0 \mathrm{E}-03$ \\
\hline & 1.5000 & $4.07394 \mathrm{E}+01$ & $1.0 \mathrm{E}-03$ \\
\hline
\end{tabular}


Table A.10. Test Cases B02_01, B02_06, and B02_09 - Reactivity Feedback

\begin{tabular}{|c|c|c|c|c|}
\hline Test Case & Reference Time, s & Output Parameter & Acceptance Value & Tolerance \\
\hline \multirow{8}{*}{$\begin{array}{c}\text { B02_01 } \\
\text { (Moderator) }\end{array}$} & \multirow{2}{*}{9.5000} & Reactor power, MW & $1.00129 \mathrm{E}+01$ & $1.0 \mathrm{E}-03$ \\
\hline & & Total Reactivity, $\$$ & $7.3181 \mathrm{E}-04$ & $1.0 \mathrm{E}-07$ \\
\hline & \multirow{2}{*}{10.0000} & Reactor power, MW & $1.00137 \mathrm{E}+01$ & $1.0 \mathrm{E}-03$ \\
\hline & & Total Reactivity, \$ & $7.2701 \mathrm{E}-04$ & $1.0 \mathrm{E}-07$ \\
\hline & \multirow{2}{*}{10.0900} & Reactor power, MW & $1.31707 \mathrm{E}+01$ & $1.0 \mathrm{E}-03$ \\
\hline & & Total Reactivity, \$ & $2.3786 \mathrm{E}-01$ & $1.0 \mathrm{E}-04$ \\
\hline & \multirow{2}{*}{10.8000} & Reactor power, MW & $8.93769 \mathrm{E}-01$ & $1.0 \mathrm{E}-05$ \\
\hline & & Total Reactivity, \$ & $-8.3796 \mathrm{E}+00$ & $1.0 \mathrm{E}-03$ \\
\hline \multirow{8}{*}{$\begin{array}{c}\text { B02_06 } \\
\text { (Doppler Effect) }\end{array}$} & \multirow{2}{*}{0.0500} & Reactor power, MW & $3.59685 \mathrm{E}+00$ & $1.0 \mathrm{E}-04$ \\
\hline & & Total Reactivity, \$ & $7.4951 \mathrm{E}-01$ & $1.0 \mathrm{E}-04$ \\
\hline & \multirow{2}{*}{0.0860} & Reactor power, MW & $4.98817 \mathrm{E}+01$ & $1.0 \mathrm{E}-03$ \\
\hline & & Total Reactivity, \$ & $1.2839 \mathrm{E}+00$ & $1.0 \mathrm{E}-03$ \\
\hline & \multirow{2}{*}{0.1243} & Reactor power, MW & $1.55893 \mathrm{E}+03$ & $1.0 \mathrm{E}-01$ \\
\hline & & Total Reactivity, \$ & $9.8598 \mathrm{E}-01$ & $1.0 \mathrm{E}-04$ \\
\hline & \multirow{2}{*}{0.1500} & Reactor power, MW & $1.72169 \mathrm{E}+02$ & $1.0 \mathrm{E}-02$ \\
\hline & & Total Reactivity, \$ & $5.2295 \mathrm{E}-01$ & $1.0 \mathrm{E}-04$ \\
\hline \multirow{8}{*}{$\begin{array}{c}\text { B02_09 } \\
\text { (Thermal expansion) }\end{array}$} & \multirow{2}{*}{0.2000} & Reactor power, MW & $2.31344 \mathrm{E}-06$ & $1.0 \mathrm{E}-10$ \\
\hline & & Total Reactivity, \$ & $6.0000 \mathrm{E}-01$ & $1.0 \mathrm{E}-04$ \\
\hline & \multirow{2}{*}{0.5000} & Reactor power, MW & $6.93118 \mathrm{E}-03$ & $1.0 \mathrm{E}-07$ \\
\hline & & Total Reactivity, \$ & $1.5000 \mathrm{E}+00$ & $1.0 \mathrm{E}-03$ \\
\hline & \multirow{2}{*}{0.6000} & Reactor power, MW & $6.73889 \mathrm{E}+00$ & $1.0 \mathrm{E}-04$ \\
\hline & & Total Reactivity, \$ & $1.4982 \mathrm{E}+00$ & $1.0 \mathrm{E}-03$ \\
\hline & \multirow{2}{*}{0.6400} & Reactor power, MW & $9.47129 \mathrm{E}+01$ & $1.0 \mathrm{E}-03$ \\
\hline & & Total Reactivity, \$ & $1.3409 \mathrm{E}+00$ & $1.0 \mathrm{E}-03$ \\
\hline
\end{tabular}

Table A.11. Test Cases B03_01 to B03_04 - Reactor Trip and Delay Time

\begin{tabular}{|c|c|c|c|c|}
\hline Test Case & Reference Time, $s$ & Output Parameter & Acceptance Value & Tolerance \\
\hline \multirow{10}{*}{$\begin{array}{c}\text { B03_01 } \\
\text { (Power trip) }\end{array}$} & \multirow{2}{*}{1.000} & Reactor power, MW & $3.20000 \mathrm{E}+01$ & $1.0 \mathrm{E}-03$ \\
\hline & & Total Reactivity, \$ & $-2.8692 \mathrm{E}-08$ & $1.0 \mathrm{E}-11$ \\
\hline & \multirow{2}{*}{1.052} & Reactor power, MW & $3.83999 \mathrm{E}+01$ & $1.0 \mathrm{E}-03$ \\
\hline & & Total Reactivity, \$ & $4.9780 \mathrm{E}-01$ & $1.0 \mathrm{E}-04$ \\
\hline & \multirow{2}{*}{1.062} & Reactor power, MW & $3.94649 \mathrm{E}+01$ & $1.0 \mathrm{E}-03$ \\
\hline & & Total Reactivity, \$ & $4.9642 \mathrm{E}-01$ & $1.0 \mathrm{E}-04$ \\
\hline & \multirow{2}{*}{1.072} & Reactor power, MW & $3.99618 \mathrm{E}+01$ & $1.0 \mathrm{E}-03$ \\
\hline & & Total Reactivity, \$ & $1.9409 \mathrm{E}-01$ & $1.0 \mathrm{E}-04$ \\
\hline & \multirow{2}{*}{1.800} & Reactor power, MW & $3.47661 \mathrm{E}+00$ & $1.0 \mathrm{E}-04$ \\
\hline & & Total Reactivity, \$ & $-1.4435 E+01$ & $1.0 \mathrm{E}-02$ \\
\hline \multirow{8}{*}{$\begin{array}{c}\text { B03_02 } \\
\text { (Period trip) }\end{array}$} & \multirow{2}{*}{1.000} & Reactor power, MW & $3.20000 E+01$ & $1.0 \mathrm{E}-03$ \\
\hline & & Reactor period, $\mathrm{s}$ & $1.4254 \mathrm{E}+07$ & $1.0 \mathrm{E}+04$ \\
\hline & \multirow{2}{*}{1.002} & Reactor power, MW & $3.22752 \mathrm{E}+01$ & $1.0 \mathrm{E}-03$ \\
\hline & & Reactor period, $\mathrm{s}$ & $1.8798 \mathrm{E}-01$ & $1.0 \mathrm{E}-04$ \\
\hline & \multirow{2}{*}{1.032} & Reactor power, MW & $3.61158 \mathrm{E}+01$ & $1.0 \mathrm{E}-03$ \\
\hline & & Reactor period, $\mathrm{s}$ & $2.8380 \mathrm{E}-01$ & $1.0 \mathrm{E}-04$ \\
\hline & \multirow{2}{*}{1.044} & Reactor power, MW & $3.68287 \mathrm{E}+01$ & $1.0 \mathrm{E}-03$ \\
\hline & & Reactor period, $\mathrm{s}$ & $6.5878 \mathrm{E}+00$ & $1.0 \mathrm{E}-03$ \\
\hline
\end{tabular}


ANL/RTR/TM-16/6 Rev. 1

\begin{tabular}{|c|c|c|c|c|}
\hline & 1000 & Reactor power, MW & $3.45457 \mathrm{E}+00$ & $1.0 \mathrm{E}-04$ \\
\hline & 1.000 & Reactor period, $\mathrm{s}$ & $-3.7924 \mathrm{E}+00$ & $1.0 \mathrm{E}-03$ \\
\hline \multirow{10}{*}{$\begin{array}{l}\text { B03_03 } \\
\text { (Flow trip) }\end{array}$} & \multirow{2}{*}{0.010} & Reactor power, MW & $3.20000 \mathrm{E}+01$ & $1.0 \mathrm{E}-03$ \\
\hline & & Mass flux, $\mathrm{kg} / \mathrm{m} 2 \mathrm{~s}$ & $-8.1308 E+03$ & $1.0 \mathrm{E}+00$ \\
\hline & \multirow{2}{*}{0.800} & Reactor power, MW & $3.08944 \mathrm{E}+01$ & $1.0 \mathrm{E}-03$ \\
\hline & & Mass flux, $\mathrm{kg} / \mathrm{m} 2 \mathrm{~s}$ & $-4.9143 E+03$ & $1.0 \mathrm{E}+00$ \\
\hline & \multirow{2}{*}{0.810} & Reactor power, MW & $3.08482 \mathrm{E}+01$ & $1.0 \mathrm{E}-03$ \\
\hline & & Mass flux, $\mathrm{kg} / \mathrm{m} 2 \mathrm{~s}$ & $-4.7943 \mathrm{E}+03$ & $1.0 \mathrm{E}+00$ \\
\hline & \multirow{2}{*}{1.400} & Reactor power, MW & $3.53737 \mathrm{E}+00$ & $1.0 \mathrm{E}-04$ \\
\hline & & Mass flux, $\mathrm{kg} / \mathrm{m} 2 \mathrm{~s}$ & $-2.4530 E+03$ & $1.0 \mathrm{E}+00$ \\
\hline & \multirow{2}{*}{1.800} & Reactor power, MW & $3.32192 \mathrm{E}+00$ & $1.0 \mathrm{E}-04$ \\
\hline & & Mass flux, $\mathrm{kg} / \mathrm{m} 2 \mathrm{~s}$ & $-8.1355 E+02$ & $1.0 \mathrm{E}-01$ \\
\hline \multirow{10}{*}{$\begin{array}{l}\text { B03_04 } \\
\text { (Flow trip) }\end{array}$} & \multirow{2}{*}{4.000} & Reactor power, MW & $2.95275 \mathrm{E}+00$ & $1.0 \mathrm{E}-04$ \\
\hline & & Mass flux, $\mathrm{kg} / \mathrm{m} 2 \mathrm{~s}$ & $-2.3301 \mathrm{E}+03$ & $1.0 \mathrm{E}+00$ \\
\hline & \multirow{2}{*}{4.093} & Reactor power, MW & $2.95098 \mathrm{E}+00$ & $1.0 \mathrm{E}-04$ \\
\hline & & Mass flux, $\mathrm{kg} / \mathrm{m} 2 \mathrm{~s}$ & $-2.3210 \mathrm{E}+03$ & $1.0 \mathrm{E}+00$ \\
\hline & \multirow{2}{*}{4.113} & Reactor power, MW & $2.95059 \mathrm{E}+00$ & $1.0 \mathrm{E}-04$ \\
\hline & & Mass flux, $\mathrm{kg} / \mathrm{m} 2 \mathrm{~s}$ & $-2.3191 \mathrm{E}+03$ & $1.0 \mathrm{E}+00$ \\
\hline & \multirow{2}{*}{4.400} & Reactor power, MW & $1.07544 \mathrm{E}+00$ & $1.0 \mathrm{E}-04$ \\
\hline & & Mass flux, $\mathrm{kg} / \mathrm{m} 2 \mathrm{~s}$ & $-2.2921 E+03$ & $1.0 \mathrm{E}+00$ \\
\hline & \multirow{2}{*}{10.000} & Reactor power, MW & 2.61430E-01 & $1.0 \mathrm{E}-05$ \\
\hline & & Mass flux, $\mathrm{kg} / \mathrm{m} 2 \mathrm{~s}$ & $-1.8305 E+03$ & $1.0 \mathrm{E}+00$ \\
\hline
\end{tabular}

Table A.12. Test Cases B04_01 - Control Rod Reactivity

\begin{tabular}{|c|l|c|c|}
\hline Reference Time, $\mathbf{s}$ & Output Parameter & Acceptance Value & Tolerance \\
\hline \multirow{2}{*}{1.000} & Reactor power, MW & $3.20000 \mathrm{E}+01$ & $1.0 \mathrm{E}-03$ \\
\cline { 2 - 4 } & Total Reactivity, $\$$ & $0.0000 \mathrm{E}+00$ & $1.0 \mathrm{E}-03$ \\
\hline \multirow{2}{*}{1.052} & Reactor power, MW & $3.84065 \mathrm{E}+01$ & $1.0 \mathrm{E}-03$ \\
\cline { 2 - 4 } & Total Reactivity, \$ & $5.0000 \mathrm{E}-01$ & $1.0 \mathrm{E}-04$ \\
\hline \multirow{2}{*}{1.062} & Reactor power, MW & $3.94806 \mathrm{E}+01$ & $1.0 \mathrm{E}-03$ \\
\cline { 2 - 4 } & Total Reactivity, $\$$ & $4.9824 \mathrm{E}-01$ & $1.0 \mathrm{E}-04$ \\
\hline \multirow{2}{*}{1.072} & Reactor power, MW & $3.99852 \mathrm{E}+01$ & $1.0 \mathrm{E}-03$ \\
\cline { 2 - 4 } & Total Reactivity, \$ & $1.9744 \mathrm{E}-01$ & $1.0 \mathrm{E}-04$ \\
\hline \multirow{2}{*}{1.562} & Reactor power, MW & $3.63778 \mathrm{E}+00$ & $1.0 \mathrm{E}-04$ \\
\cline { 2 - 4 } & Total Reactivity, \$ & $-1.4540 \mathrm{E}+01$ & $1.0 \mathrm{E}-02$ \\
\hline
\end{tabular}


Table A.13. Test Cases B05_05 and B05_06 - Decay Heat

\begin{tabular}{|c|c|c|c|}
\hline \multirow{2}{*}{ Test Case } & $\begin{array}{c}\text { Reference } \\
\text { Time, } \mathbf{s}\end{array}$ & $\begin{array}{c}\text { Acceptance Value for } \\
\text { Reactor Power, MW }\end{array}$ & Tolerance \\
\hline \multirow{3}{*}{$\begin{array}{c}\text { B05_05 } \\
\text { (ANS 2005) }\end{array}$} & 0.001 & $3.20000 \mathrm{E}+01$ & $1.0 \mathrm{E}-03$ \\
\cline { 2 - 4 } & 1.000 & $3.20000 \mathrm{E}+01$ & $1.0 \mathrm{E}-03$ \\
\cline { 2 - 4 } & 1.072 & $3.99618 \mathrm{E}+01$ & $1.0 \mathrm{E}-03$ \\
\hline & 40.000 & $1.27221 \mathrm{E}+00$ & $1.0 \mathrm{E}-04$ \\
\hline \multirow{3}{*}{$\begin{array}{c}\text { B05_06 } \\
\text { (ANS 1973) }\end{array}$} & 0.001 & $3.20000 \mathrm{E}+01$ & $1.0 \mathrm{E}-03$ \\
\cline { 2 - 4 } & 1.000 & $3.20000 \mathrm{E}+01$ & $1.0 \mathrm{E}-03$ \\
\cline { 2 - 4 } & 1.072 & $3.99632 \mathrm{E}+01$ & $1.0 \mathrm{E}-03$ \\
\cline { 2 - 4 } & 40.000 & $1.34948 \mathrm{E}+00$ & $1.0 \mathrm{E}-04$ \\
\hline
\end{tabular}

Note: As the calculation of fission power can be confirmed by the previous test cases (B01_xx, B02_xx, B03_xX, and B04_xx), the checking of total power in these two cases is enough to ensure the calculation of decay heat using ANS2005 and ANS193 decay models.

Table A.14. Test Cases B06_03 - Power-Driven Mode

\begin{tabular}{|c|l|c|c|}
\hline Reference Time, $\mathbf{s}$ & Output Parameter & Acceptance Value & Tolerance \\
\hline \multirow{2}{*}{1.0000} & Reactor power, MW & $1.32499 \mathrm{E}+01$ & $1.0 \mathrm{E}-03$ \\
\cline { 2 - 4 } & Peak Fuel Temp., ${ }^{\circ} \mathrm{C}$ & $1.1338 \mathrm{E}+02$ & $1.0 \mathrm{E}-01$ \\
\hline \multirow{2}{*}{1.0400} & Reactor power, MW & $4.07249 \mathrm{E}+01$ & $1.0 \mathrm{E}-03$ \\
\cline { 2 - 4 } & Peak Fuel Temp., ${ }^{\circ} \mathrm{C}$ & $1.6102 \mathrm{E}+02$ & $1.0 \mathrm{E}-01$ \\
\hline \multirow{2}{*}{1.1400} & Reactor power, MW & $2.92730 \mathrm{E}+01$ & $1.0 \mathrm{E}-03$ \\
\cline { 2 - 4 } & Peak Fuel Temp., ${ }^{\circ} \mathrm{C}$ & $1.8275 \mathrm{E}+02$ & $1.0 \mathrm{E}-01$ \\
\hline \multirow{2}{*}{1.5000} & Reactor power, MW & $3.24356 \mathrm{E}+01$ & $1.0 \mathrm{E}-03$ \\
\cline { 2 - 4 } & Peak Fuel Temp., ${ }^{\circ} \mathrm{C}$ & $1.9023 \mathrm{E}+02$ & $1.0 \mathrm{E}-01$ \\
\hline \multirow{2}{*}{2.0000} & Reactor power, MW & $1.86803 \mathrm{E}+00$ & $1.0 \mathrm{E}-03$ \\
\cline { 2 - 4 } & Peak Fuel Temp., ${ }^{\circ} \mathrm{C}$ & $6.4078 \mathrm{E}+01$ & $1.0 \mathrm{E}-02$ \\
\hline
\end{tabular}




\section{Argonne}

\section{Nuclear Science \& Engineering Division}

Argonne National Laboratory

9700 South Cass Avenue, Bldg. 208

Argonne, IL 60439

www.anl.gov 